\title{
VIGILÂNCIA DAS HEPATITES VIRAIS: A EXPERIÊNCIA DE VARGEM GRANDE PAULISTA, 1997-1999
}

Dissertação apresentada a Faculdade de Saúde Pública da Universidade de São Paulo para obtenção do título de mestre.

Área de concentração: Epidemiologia

Orientador: Prof. Dr. Eliseu Alves Waldman

\section{SÃO PAULO}




\section{ÍNDICE}

Termos e abreviaturas ___ II

Resumo __ III

Summary VI

1. Introdução 1

1.1. Etiologia das hepatites virais

1.1.1. Vírus da hepatite A 3

1.1.2. Vírus da hepatite B _ 4

1.1.3. Vírus da hepatite $\mathrm{C} \longrightarrow 5$

1.1.4. Vírus da hepatite D

$\begin{array}{ll}\text { 1.1.5. Vírus da hepatite } \mathrm{E} & 6\end{array}$

$\begin{array}{ll}\text { 1.1.6. Outros vírus associados às } & 6\end{array}$

1.2. Aspectos clínicos e evolução das hepatites 8

$\begin{array}{ll}\text { 1.2.1. Hepatite aguda } 10 & 10\end{array}$

1.2.2. Hepatite crônica __ 11

1.3. Diagnóstico das hepatites virais $\quad 13$

$\begin{array}{ll}\text { 1.3.1. Hepatite A } 14 & 14\end{array}$

$\begin{array}{ll}\text { 1.3.2. Hepatite B } 15 & 15\end{array}$

1.3.3. Hepatite C — 18

1.3.4. Hepatite D — 21

1.3.5. Hepatite E — 23

1.4. Epidemiologia das hepatites virais __ 25

$\begin{array}{ll}\text { 1.4.1. Hepatite A } 25 & 25\end{array}$

1.4.2. Hepatite B 29

$\begin{array}{ll}\text { 1.4.3. Hepatite C } & 33 \\ \text { 1.4.4. Hepatite D } & 35\end{array}$

\begin{tabular}{lll} 
1.4.4. Hepatite D & 35 \\
\hline & &
\end{tabular}

$\begin{array}{ll}\text { 1.4.5. Hepatite E } & 37\end{array}$

2. Objetivos — 41

3. Material e métodos — 42

3.1. Área de estudo _ 44

3.2. Descrição do sistema de _ 
3.2.1. Objetivos do sistema

46

3.2.2. Definições de casos 46

3.2.3. Componentes do sistema 47

3.2.4. Fluxograma do sistema

3.2.5. Procedimentos para aumentar a sensibilidade do

3.2.6. Procedimentos de laboratório 48

.

3.3. Investigação de surtos

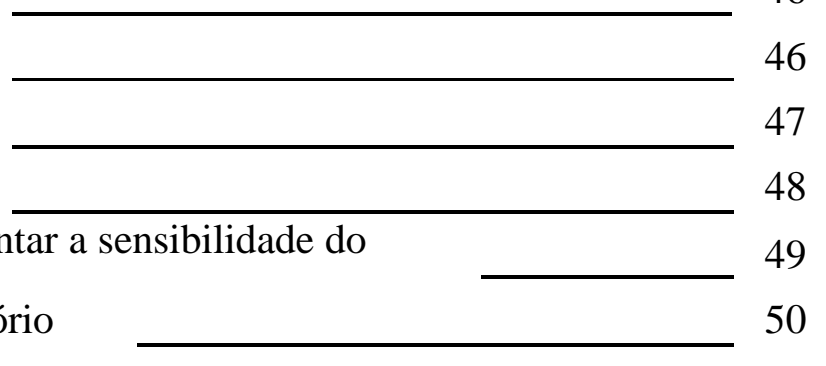

3.4. Prevalência de marcadores de hepatite A, B, C e E em

3.5. Aspectos éticos 53

Resultados 55

4.1. Caracterização das hepatites virais com fundamento em dados de notificação 57

4.1.1. Caracterização dos casos suspeitos 57

4.1.2. Caracterização dos casos confirmados 59

4.1.3. Características dos casos de hepatite A 61

4.1.3.1. Investigação do surto de hepatite $\mathrm{A}$ 64

4.1.4. Características dos casos de hepatite $B$ 69

4.1.5. Características dos casos de hepatite $\mathrm{C}$ 70

4.1.6. Características dos casos de hepatite $\mathrm{E}$ 4.1.7. Incidência das hepatites A, B e E e prevalência da 71 . . . C .

4.2. Prevalência dos marcadores das hepatites A, B, C e E em gestantes

4.3. Impacto da implantação do sistema de vigilância no

\section{Discussão}

6. Referências

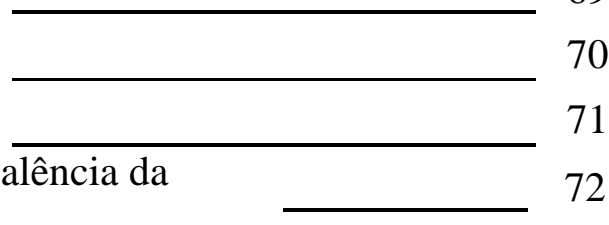

7. Anexos

Anexo 1 - Ficha de investigação laboratorial - suspeito 73 75

Anexo 2 - Ficha de investigação laboratorial - gestante

Anexo 3 - Ficha de investigação epidemiológica 76

Anexo 4 - Termo de consentimento livre e esclarecido (suspeito) 95

Anexo 5 - Termo de consentimento livre e esclarecido (gestante) 113 114 115 116 119 120 


\section{TERMOS E ABREVIATURAS}

ALT (TGP) alanina amino transferase

Anti-VHA anticorpo total contra o vírus da hepatite A

Anti-HBc anticorpo total contra o antígeno do core do vírus da hepatite B

Anti-HBc IgM anticorpo IgM contra o antígeno do core do vírus da hepatite B

Anti-HBe anticorpo contra o antígeno $e$ do vírus da hepatite $\mathrm{B}$

Anti-HBs anticorpo contra o antígeno de superfície do vírus da hepatite B

Anti-VHA IgG anticorpo da classe IgG contra o vírus da hepatite A

Anti-VHA IgM anticorpo da classe IgM contra o vírus da hepatite A

Anti-VHC anticorpo total contra o vírus da hepatite C

Anti-VHD anticorpo contra o vírus da hepatite D

Anti-VHE anticorpo total contra o vírus da hepatite E

AST (TGO) aspartato amino transferase

DNA ácido desoxirribonucléico

GBV-C/HGV vírus da hepatite G

HBcAg antígeno do core do vírus da hepatite B

HBeAg antígeno $e$ do vírus da hepatite $\mathrm{B}$

HBsAg antígeno de superfície do vírus da hepatite B

HIV vírus da imunodeficiência humana

HNANB hepatite não A não $B$.

IgG imunoglobulina da classe $\mathrm{G}$

IgM imunoglobulina da classe $\mathbf{M}$

nm nanômetro

PCR reação em cadeia da polimerase

RNA ácido ribonucléico

UI/L unidades internacionais por litro

VHA vírus da hepatite A

VHB vírus da hepatite $B$

VHC vírus da hepatite $C$

VHD vírus da hepatite D

VHE vírus da hepatite $\mathrm{E}$ 
RESUMO

Não se tem conhecimento preciso da relevância e magnitude das hepatites em nosso país. Os poucos estudos epidemiológicos estão restritos à populações atendidas em serviços de saúde ou a grupos de risco para as hepatites. A vigilância é um instrumento de saúde pública que tem a capacidade de descrever o comportamento das hepatites virais, bem como identificar seus fatores de risco.

Um sistema de vigilância das hepatites A, B, C e E foi implantado em Vargem Grande Paulista em abril de 1997 e mantido até setembro de 1999. O objetivo foi analisar aspectos da operacionalização de um sistema de vigilância nas atuais condições de trabalho da Rede Pública de Saúde e sua potencialidade em descrever o comportamento das hepatites nessa comunidade para oferecer subsídios para elaboração e aprimoramento de estratégias de controle.

O sistema incluiu a análise de dados obtidos a partir de notificação de casos suspeitos hepatite A, B, C e E entre residentes no município, assim como dados de soroprevalência de marcadores de infecção para esses mesmos vírus numa população formada pelas gestantes inscritas no Serviço Pré-natal do Município.

Considerou-se caso suspeito o indivíduo residente no município de Vargem Grande Paulista e para quem, por critérios clínicos, laboratoriais ou epidemiológicos, foi solicitada a determinação dos níveis de bilirrubinas e transaminases. A confirmação dos casos foi realizada pela identificação dos marcadores sorológicos das hepatites A, B, C e E.

Foram identificados 125 casos suspeitos, dos quais 41 (32,8\%) foram confirmados como hepatite A, B, C ou E. A incidência de hepatite A foi 21,1/100.000 hab., 69,3/100.000 hab. e 9,3/100.000 hab. para os anos de 1997, 1998 e 1999, respectivamente. Foi detectado um surto de hepatite A em um dos bairros do município envolvendo 18 casos, no primeiro semestre de 1998. A forma predominante de transmissão do vírus durante o surto foi pessoa a pessoa e a faixa etária mais atingida foi de 5 a 9 anos. A incidência de hepatite B foi de 3,5/100.000 hab. e 9,9/100.000 hab. para os anos de 1997 e 1998 respectivamente. Não foi identificado nenhum caso em 1999. A prevalência de hepatite C foi 3,5/100.000 hab. 
em 1997 e 9,9/100.000 hab. em 1998. Não foi calculada a incidência de hepatite C, porque não foi possível determinar se a infecção pelo VHC era recente ou não com os testes utilizados. A incidência de hepatite E foi 3,5/100.000 hab., 3,3/100.000 hab. e 3,1/100.000 hab. para 1997, 1998 e 1999.

Entre as 793 gestantes que participaram do estudo, a prevalência de anti-VHA foi de 94,7\%, de anti-HBc 4,9\%, de HBsAg 0,1\%, de anti-VHC 0,6\%, e anti-VHE $0,8 \%$.

Os resultados indicaram que Vargem Grande Paulista apresentou alta endemicidade para hepatite A e baixa endemicidade para hepatite B. A prevalência de hepatite $\mathrm{C}$ foi semelhante à encontrada em outros estudos. A prevalência e incidência da hepatite $\mathrm{E}$ mostrou que o vírus circulou na região. Os dados demonstraram que o sistema de vigilância pode contribuir com informações importantes no comportamento das hepatites virais no município, oferecendo subsídios para a elaboração de estratégia de prevenção e controle dessas infecções. 
SUMMARY

A surveillance system of the hepatitis A, B, C and E was implanted in Vargem Grande Paulista In April, 1997 and maintained to September, 1999. The present study was implanted in order to analyze aspects of the surveillance system operation in the current conditions of the Public Health Service and its potentiality in describing the behavior of the hepatitis in that community to be used for elaboration and improvement of control strategies.

The system included the analysis of data obtained of the notification of hepatitis A, B, C and E cases among the residents of the Municipal District, as well data of seroprevalence markers in a population formed by the pregnants registered in the Prenatal Service.

The system considered suspected case the resident in Vargem Grande Paulista for who was requested the determination of the bilirubin and aminotransferases levels, by clinical, laboratory or epidemiologic criteria. The confirmation of the cases was accomplished by the identification of the hepatitis A, B, C and E serologic markers.

Of the 125 suspected cases identified, 41 (32.8\%) were confirmed as hepatitis A, B, C or E. The incidence of hepatitis A was 21.1 per 100,000 population, 69.3 per 100,000 and 9.3 per 100,000 for the years of 1997, 1998 and 1999, respectively. In the first semester of 1998, it was detected a hepatitis A outbreak in one of the neighborhoods, involving 18 cases. The predominant form of transmission, during the outbreak, was person to person and the 5 to 9 age-group was the most affected. The hepatitis B incidence was 3.5 per 100,000 and 9.9 per 100,000 pop. for the years of 1997 and 1998, respectively. It was not identified any case in 1999. The hepatitis C prevalence was 3.5 per 100,000 in 1997 and 9.9 per 100,000 in 1998 and its incidence was not calculated because it was not possible to determine if the $\mathrm{HCV}$ infection was recent or not with the used tests. The hepatitis $E$ incidence was 3.5 per 100,000, 3.3 per 100,000 and 3.1 per 100,000 for 1997, 1998 and 1999, respectively.

Among the 793 pregnants, the anti-HAV prevalence was $94.7 \%$, anti- $\mathrm{HBc}$ 4.9\%, HBsAg 0.1\%, anti-HCV 0.6\% and anti-HEV $0.8 \%$. 
The results indicated that Vargem Grande Paulista presented high endemicity for hepatitis A and lower for hepatitis B. The hepatitis $\mathrm{C}$ prevalence was similar to other studies. The hepatitis E prevalence and incidence showed that the virus circulated in the area. The data demonstrate that the surveillance system can contribute with important information to understand the behavior of the viral hepatitis to the Municipal District, can be subsidies for the elaboration of prevention and control strategy. 


\section{INTRODUÇÃ̃}

Os primeiros relatos de casos com quadro clínico compatíveis com hepatites de etiologia possivelmente infecciosa datam de mais de 2000 anos, quando Hipócrates descreveu uma epidemia de doença ictérica (ZUCKERMAN e THOMAS 1998). Porém, foi só no início deste século que os estudos das hepatites se intensificaram e o termo "hepatite infecciosa" passou a ser usado para descrever a forma epidêmica desta doença. Em 1918, essa síndrome foi relacionada a uma provável etiologia viral. Etiologia posteriormente confirmada por estudos epidemiológicos, incluindo experimentos realizados em voluntários humanos durante a Segunda Guerra Mundial. Estes estudos permitiram distinguir duas formas de contágio desta doença: uma de transmissão oral-fecal, que recebeu a denominação de hepatite infecciosa, e outra de transmissão parenteral, denominada de hepatite sorohomóloga (PINHO e col. 1995; SILVA 1995a; HOLLINGER 1996; PARANÁ 1997; ZACHOVAL e DEINHARDT 1998).

Desde então, houve expressiva ampliação dos conhecimentos a respeito das hepatites virais, principalmente na última década. Esses avanços tiveram início com o registro de casos esporádicos ou de surtos epidêmicos, possibilitando entender melhor a epidemiologia das hepatites (KNIGHT 1954), e se estendem até hoje com a aplicação de técnicas de biologia molecular, que permitem a identificação de novos vírus associados às hepatites em seres humanos e o desenvolvimento de novas vacinas (HALL 1996; REGEV e SCHIFF 1999).

Apesar desses grandes avanços, as hepatites virais continuam entre as causas mais comuns de doença aguda e crônica do fígado, situando-se entre os principais problemas de saúde pública em todo mundo. Em 1993, cerca de 43.000 casos de hepatite viral foram registrados no Centers for Disease and Control (CDC) nos Estados Unidos da América do Norte, com incidência estimada de 17 casos por 100.000 habitantes (HOLLINGER 1996). Entretanto, o número real de casos deve ser bem superior; estima-se que anualmente, em média, 180.000 norte-americanos 
sejam infectados pelo vírus da hepatite A (VHA), 200.000 pelo vírus da hepatite B (VHB) e 36.000 pelo vírus da hepatite C (VHC). Como conseqüência são estimadas 100 mortes por hepatite A fulminante, de 5.000 a 6.000 por hepatite B e entre 8.000 e 10.000 por hepatite C (CDC 2000; HFI 2000).

\subsection{ETIOLOGIA DAS HEPATITES VIRAIS}

Atualmente, aceita-se a existência de 8 vírus como agentes etiológicos das hepatites. Esses vírus, apesar de apresentarem quadros clínicos bastante semelhantes, foram classificados em diversos gêneros, com características funcionais e estruturais extremamente distintas.

\subsubsection{VÍRUS DA HEPATITE A}

O vírus da hepatite A (VHA) foi visualizado pela primeira vez, por FEISTONE e col., em 1973, por meio da microscopia eletrônica, em amostra de fezes, recebendo a denominação de Enterovirus 72. Entretanto, em 1991, após a descoberta de uma série de diferenças entre o VHA e os enterovírus, o VHA foi classificado em um novo gênero: o Hepatovirus, pertencente à família Picornaviridae. Seu genoma viral é constituído por uma molécula de RNA de fita simples. Foram descritos 4 genótipos humanos que possuem o mesmo sorotipo. O VHA é um vírus pequeno, de 27 a 32 nm, não envelopado (MELNICK 1992; PINHO e col. 1995; KOFF 1998).

\subsubsection{VÍRUS DA HEPATITE B}

Remonta a 1885 a primeira documentação de uma forma de hepatite de transmissão parenteral, mas o termo hepatite B só foi usado para defini-la em 1947, por Mac Callum (PINHO e col. 1995). Na década de 60, BLUMBERG e col (1965) identificaram o antígeno Austrália, assim denominado por ter sido detectado no soro de um aborígene australiano. Posteriormente, descobriu-se que esse antígeno correspondia ao antígeno do envelope do vírus da hepatite B (VHB). A partícula íntegra do VHB foi visualizada pela primeira vez em 1970, por DANE e col.

$\mathrm{O}$ vírus da Hepatite $\mathrm{B}$ pertence à família Hepadnaviridae, gênero Orthohepadnavirus. O VHB completo (partícula de Dane) é um vírus de DNA, 
envelopado, com o diâmetro de $42 \mathrm{~nm}$. Apresenta diferentes componentes antigênicos, que podem ser divididos em dois grupos: antígenos de superfície e antígenos centrais (PINHO e col. 1995; MAHONEY 1999).

$\mathrm{O}$ antígeno de superfície do $\mathrm{VHB}, \mathrm{HBsAg}$, é o principal antígeno do envelope. É antigenicamente heterogêneo, com um determinante comum designado $a$, e dois pares de determinantes mutuamente exclusivos, $\mathrm{d}$ ou y e $\mathrm{w}$ ou $\mathrm{r}$, que definem quatro principais subtipos: adw, ayw, adr, ayr. Não foram relatadas diferenças nos aspectos clínicos das hepatites associadas a estes diferentes subtipos. Por apresentarem diferenças na distribuição geográfica, os subtipos têm importância em estudos epidemiológicos. Os anticorpos neutralizantes são dirigidos contra o determinante a, por isso, vacinas produzidas contra um subtipo são também eficazes contra outros. Na região central ou cerne ou ainda "core", são encontrados dois antígenos: o antígeno do core ( $\mathrm{HBcAg})$, não detectável livre no soro, e o antígeno e (HBeAg) encontrado em forma solúvel no soro de pacientes infectados (BENENSON 1995; KANN e GERLICH 1998; PINHO e col. 1995; GROB 1998).

Recentemente, tornou-se mais freqüente a utilização da classificação do VHB fundamentada nas semelhanças da seqüência nucleotídica, que divide o VHB em 6 genótipos de A a F (OKAMOTO e col. 1988; NORDER e col. 1992; PINHO 1999).

\subsubsection{VÍRUS DA HEPATITE C}

Outro agente recentemente identificado foi o vírus da hepatite $\mathrm{C}$, responsável pela maioria dos casos até então denominados de hepatite não-A, não-B (HNANB) de transmissão parenteral. Por várias décadas, o diagnóstico desta infecção baseavase na exclusão da hepatite A e B. Foi em 1989, que o vírus da hepatite C (VHC) foi identificado e clonado por Choo e col., utilizando técnicas complexas de biologia molecular. Posteriormente, estas técnicas foram utilizadas para o desenvolvimento de testes sorológicos para o seu diagnóstico (CHOO e col. 1989). O VHC é um vírus de RNA envelopado com aproximadamente $50 \mathrm{~nm}$ de diâmetro. Pertence à família Flaviviridae, gênero Hepacivirus (PURCELL 1997). O VHC apresenta grande variabilidade genética e está classificado em 6 diferentes genótipos, divididos em diferentes subtipos (SIMMONDS e col. 1994; STUYVER 1996; DI BISCEGLIE 1998). 


\subsubsection{VÍRUS DA HEPATITE D}

Em 1977, Rizzeto e col. detectaram nos núcleos de hepatócitos de um paciente com falência hepática fulminante, uma partícula viral que denominaram de "agente delta". Estudos efetuados por meio de inoculação em chimpanzé provaram, poucos anos depois, que este agente tratava-se de um componente de um vírus associado ao VHB, que recebeu o nome de vírus da hepatite delta e posteriormente, de vírus da hepatite $\mathrm{D}$ (VHD). O VHD é um vírus pequeno, defectivo que necessita do VHB para sua expressão. É composto de um envoltório de HBsAg, de uma porção interna de RNA e de uma proteína chamada delta. A infecção pelo VHD pode ser simultânea à infecção pelo VHB, caracterizando a co-infecção, ou pode ser posterior, causando a superinfecção (BENENSON 1995; PERRENOUD 1995; PINHO e col. 1995; TAYLOR 1999).

\subsubsection{VÍRUS DA HEPATITE $E$}

Em 1955, foi descrita pela primeira vez, em Nova Delhi, Índia, uma epidemia de hepatite ictérica, com o registro de cerca de 29.000 casos após a contaminação do sistema de abastecimento de água com o esgoto (FAVOROV e col. 1992).. Apesar da transmissão ser fecal-oral, as características desta epidemia e de outras similares descritas em 1975 e 1976, diferiam das características das epidemias ocasionadas pelo VHA, por exemplo: a incidência parecia ser maior em adultos jovens, com significativa taxa de mortalidade em gestantes (PANDA e JAMEEL 1997).

Esta hepatite ficou conhecida, genericamente, como hepatite não-A não-B de transmissão entérica até ser identificado, em 1988, o vírus da hepatite E (VHE). É um vírus de RNA, não-envelopado, seu tamanho varia de 27 a 34nm. Está provisoriamente classificado na família Caliciviridae. Esta classificação deve ser revista devido às diferenças com outros vírus desta família (TAM e BRADLEY 1998, HARRISON 1999).

\subsubsection{OUTROS VÍRUS ASSOCIADOS ÀS HEPATITES}

Mesmo com a identificação dos vírus A, B, C, D e E, cerca de $20 \%$ dos casos de hepatite que apresentavam quadro clínico e epidemiológico sugestivos de envolvimento viral ficaram sem identificação (PINHO E BERNARDINI 1999). 
Essas hepatites de provável etiologia viral foram denominadas hepatites não-A, não$\mathrm{B}$, não-C, não-D, não-E, ou simplesmente hepatites não A-E. A partir desses casos, e com o desenvolvimento de técnicas de biologia molecular extremamente sensíveis, foram descobertos recentemente três diferentes vírus potencialmente envolvidos com hepatites em seres humanos.

O primeiro foi identificado por dois grupos de pesquisadores distintos, recebendo de cada um deles uma denominação diferente, vírus GB-C ou vírus da Hepatite G (GBV-C/HGV), que constituem diferentes isolados do mesmo vírus (SIMONS e col. 1995; LINNEN e col. 1996). Devido às semelhanças genéticas com o VHC, este vírus foi classificado na família Flaviviridae, constituindo um gênero à parte que ainda não recebeu denominação final. A forma de transmissão mais bem documentada é por via parenteral, especialmente por transfusões sangüíneas, entretanto já foi observada a transmissão vertical de mãe para filho. A transmissão sexual foi sugerida em virtude da alta freqüência em homens que fazem sexo com homens, profissionais do sexo e entre casais (PINHO e SILVA 2001). A detecção da infecção ativa por este agente é feita por reação da polimerase em cadeia (PCR), enquanto que a detecção das proteínas do envelope é feita por ensaio imunoenzimático, muito raramente os dois marcadores são encontrados ao mesmo tempo (PINHO e BERNARDINI 1999; ALTER e col. 1997). O vírus é encontrado em casos de hepatite NANE em diferente regiões do mundo, alguns com quadro clínico grave. Como este vírus também está presente em indivíduos assintomáticos, sua associação com o desenvolvimento de hepatite é questionada (PINHO e SILVA 2001).

No final de 1996, Okamoto e col. relataram a identificação de um outro vírus associado a hepatite pós-transfusional de etiologia desconhecida, clonado do plasma de um doador de sangue com os níveis de transaminases elevados e sem nenhum marcador das hepatites virais conhecidas (NISHIZAWA e col. 1997; OKAMOTO e col. 1998) . Esse novo vírus foi denominado TTV devido as iniciais do nome do paciente (TT) de quem foi isolado, e que por coincidência pode se referir a "transfusion-transmitted virus" (NISHIZAWA e col. 1997). É encontrado no sangue, nas fezes, na bile e na saliva, sugerindo que sua transmissão ocorra tanto por via sangüínea como por fecal-oral. A detecção do seu genoma, constituído por DNA, é 
feita por PCR. O vírus foi encontrado no Japão em $47 \%$ dos casos de hepatite fulminante não A-G e em 12\% dos doadores de sangue (OKAMOTO e col. 1998). Posteriormente, na Europa e nos EUA, sua presença foi relatada entre doentes com hepatite não A-G, e também entre indivíduos sãos (PINHO e BERNARDINI 1999). Estudo realizado em São Paulo, detectou o TTV em 20\% dos casos de hepatite não A-E. O vírus foi, também, encontrado em $45 \%$ dos casos de hepatopatias crônicas do

Estado do Pará (PINHO e col. 1998). Entre doadores de sangue de Campinas, foi encontrado em 16,7\% dos doadores com níveis de ALT normal e em 17,7\% com níveis elevados (PINHO e col. 1999). A associação desse vírus com quadros de hepatite aguda ou crônica ainda não está bem definida (COSSART 2000; FABRIS e col. 2000; KATO 2000)

Recentemente, um vírus de DNA designado SEN vírus (SEN-V) foi descoberto no soro de um usuário de droga endovenosa infectado com o vírus da imunodeficiência humana (HIV) (TANAKA e col. 2001). A análise filogenética do SEN-V mostrou a diferença 8 genótipos diferentes do vírus (A-H). O SENV-D e o SENV-H são os mais prevalentes no soro de pacientes com hepatite não A-E póstransfusional e menos freqüentes entre os doadores de sangue, entretanto a participação desse vírus como agente causal nashepatite pós-transfusional ainda não está estabelecida (TANAKA e col. 2001; UEMURA e col. 2001). A grande maioria dos indivíduos que receberam sangue contaminado com SEN-V não desenvolveram hepatite (UEMURA e col. 2001). Um estudo demonstrou sua presença em $80 \%$ dos casos de hepatite não A-E e em 1 a $8 \%$ dos controles sãos. O SEN-V foi também encontrado em $30 \%$ dos pacientes com AIDS, sugerindo que os meios de transmissão desse vírus sejam os mesmos do HIV (PINHO e col. 1999).

\subsection{ASPECTOS CLÍNICOS DAS HEPATITES VIRAIS}

O quadro clínico das hepatites virais pode variar de manifestações pouco intensas e passageiras, com a cura completa, até manifestações graves e prolongadas, em que o paciente pode desenvolver uma hepatite grave evoluindo, com alguma freqüência para a morte. (HOLLINGER e TICEHURST 1996; SHERLOCK 1998).

Como o curso das hepatites virais pode ser extremamente variável, diversos termos têm sido utilizados para caracterizar cada uma das formas de apresentação da 
doença. Os termos hepatite inaparente e anictérica são freqüentemente confundidos e utilizados de maneira incorreta como sinônimos. Pacientes com hepatite inaparente ou subclínica não apresentam sintomas ou icterícia. Estes casos assintomáticos só podem ser identificados por exames bioquímicos e sorológicos. Por outro lado, os sintomas clínicos, quando presentes, podem estar acompanhados por icterícia, caracterizando uma hepatite ictérica. O termo hepatite anictérica fica reservado para os casos que apresentam sintomas mas não desenvolvem icterícia (HOLLINGER e TICEHURST 1996).

Vários fatores podem interferir na evolução das hepatites virais e podem ser relacionados ao agente etiológico, como tipo de vírus, replicação e resistência às drogas, ou relacionados ao paciente, como idade, estado imunológico, gestação, consumo de álcool e drogas ilícitas, assim como a capacidade regenerativa do fígado. A associação com outros vírus hepatotrópicos ou outros patógenos também interferem neste processo (ALVES e GAYOTTO 1995; SILVA 1995c; FOCACCIA e CONCEIÇÃO 1997; HOOFNAGLE e TRALKA 1997; DECKER 1998). Por exemplo, pacientes que se infectam com o VHA e têm hepatite C crônica têm risco maior de desenvolver hepatite fulminante e morrer do que aqueles que não têm (VENTO e col. 1998; REGEV 1999; SOKAL e BORTOLOTTI 1999).

$\mathrm{Na}$ maioria dos casos, as hepatites virais evoluem para cura com o desaparecimento do quadro clínico em poucas semanas e a normalização das enzimas hepáticas em poucos meses. Essa é a forma mais comum de evolução da doença, porém existem várias possibilidades evolutivas, que serão apresentadas numa classificação que as dividem em dois grupos: hepatite aguda e hepatite crônica (SILVA 1995c; FOCACCIA e CONCEIÇÃO 1997; SHERLOCK 1998). 


\subsubsection{HEPATITE AGUDA}

Independente do vírus envolvido, o curso da hepatite aguda típica é similar e pode ser dividido em quatro fases clínicas (SILVA 1995b; HOLLINGER e TICEHURST 1996):

a) período de incubação: neste intervalo de tempo, compreendido entre a entrada do vírus no organismo e o aparecimento dos sintomas; o paciente permanece assintomático, ainda que o vírus esteja se replicando; raramente é útil para determinar a etiologia de casos individuais de hepatite porque é bastante variável para cada um dos vírus;

b) fase prodrômica ou pré-ictérica: caracteriza-se por um conjunto de sintomas não específicos que antecedem o aparecimento da icterícia; eventualmente esta fase pode não se manifestar, surgindo a icterícia como o primeiro sintoma; os sintomas mais freqüentes são os característicos de "estado gripal" e os digestivos, como anorexia, náuseas, vômitos e desconforto abdominal, a febre pode ou não estar presente;

c) fase ictérica: tem duração e intensidade muito variável, caracteriza-se pelo escurecimento da urina (colúria), devido à presença da bilirrubina, seguido de icterícia e fezes esbranquiçadas (acolia); nesse período, podem persistir alguns dos sintomas da fase pré-ictérica, principalmente os digestivos, mas, em geral, o paciente volta a sentir-se mais disposto;

d) fase de convalescença: os sintomas clínicos vão gradativamente desaparecendo, quando são encontradas apenas discretas alterações enzimáticas.

Hepatite colestática, fulminante, polifásica são manifestações atípicas da hepatite aguda. A hepatite colestática é caracterizada pela eliminação por um período prolongado de fezes acólicas e pela presença de prurido com icterícia progressiva e intensa, o que pode persistir por vários meses. O processo é benigno, com evolução habitual para cura. É pouco freqüente e tem sido observada em adultos com hepatite A. (SCHIFF 1992, SILVA 1995b, HOLLINGER e TICEHURST 1996; KOFF 1998).

A expressão clínica mais grave da hepatite aguda é a forma fulminante. Também denominada de insuficiência hepática aguda grave (IHAG), caracteriza-se 
pelo aparecimento de encefalopatia, dentro das primeiras oito semanas, com ausência de enfermidade hepática prévia. Menos de $1 \%$ dos casos evolui para hepatite fulminante, levando à morte de $70 \%$ a $90 \%$ dos pacientes, sendo que a letalidade aumenta com a idade. (o'Grady 1992; ALVES e GAYOTTO 1995; HOLLINGER 1996). A ocorrência é rara, porém é mais freqüente na hepatite D (FONSECA e BRASIL 1995; PURCELL e GERIN 1996) e em gestantes com hepatite E do que nas outras hepatites virais. A letalidade das gestantes situa-se em torno de $25 \%$, principalmente no terceiro trimestre. Outro aspecto peculiar da hepatite E é que, diferentemente das outras hepatites, o VHE causa infecção intrauterina, assim como substancial morbidade e mortalidade perinatal (PANDA e JAMEEL 1997, PURCELL 1996, YARBOUGH 1999).

Em alguns casos, após a recuperação inicial das manifestações clínicas e bioquímicas, ocorre o aumento dos níveis de transaminases (recaída). Esta forma de hepatite aguda é chamada de polifásica e é observada em 3 a 20\% dos casos agudos de hepatite A. A recaída da doença, pode ser mais ou menos severa que o episódio original, ocorre cerca de 15 semanas após os sintomas iniciais terem desaparecido. Anticorpos da classe IgM também reaparecem ou o título aumenta, e o vírus pode ser encontrado nas fezes e no soro (SILVA e MADRUGA 1995; HOLLINGER e TICEHURST 1996, ZACHOVAL e DEINHARDT 1998).

\subsubsection{HEPATITE CRÔNICA}

As hepatites crônicas representam um problema de grande importância clínica e terapêutica, especialmente porque parte dos casos podem evoluir para cirrose ou até mesmo carcinoma hepatocelular. Caracterizam-se pela persistência de lesão hepática associada a níveis elevados de transaminases e marcadores virais por mais de seis meses. Como é possível a persistência da infecção por meses e até anos sem haver lesão necro-inflamatória do tecido, especialmente em infecções pelo VHB e VHC, o diagnóstico definitivo da hepatite crônica requer o estudo histológico por biópsia hepática (SILVA 1995c; HOLLINGER 1996, MAHONEY 1999).

A hepatite crônica é mais freqüente nas hepatites causadas pelos vírus $\mathrm{B}, \mathrm{C}$ e D. Entre 2 e $8 \%$ dos adultos infectados pelo VHB desenvolvem hepatite crônica, contrastando com as elevadas taxas encontradas em recém-nascidos de mães 
portadoras de HBeAg, próximas de 90\% (ALVES e GAYOTTO 1995; HOLLINGER 1996; DECKER 1998; MAHONEY 1999). Das hepatites virais, a C é a que apresenta maior proporção de casos que evoluem para cronicidade, cerca de 85\% (HOOFNAGLE e TRALKA 1997; DI BISCEGLIE 1998). Não há relatos de casos com critétios histopatológicos que comprovem a evolução para cronicidade das hepatites A e E (ALVES e GAYOTTO 1995; ZACHOVAL e DEINHARDT 1998; KOFF 1998; YARBOUGH 1999).

Pessoas com hepatite crônica podem ou não ter história de hepatite aguda. Cerca de um terço dos casos têm transaminases elevadas, a biópsia hepática pode revelar células normais ou com lesões características de hepatite crônica ativa, com ou sem cirrose. Pacientes podem ser totalmente assintomáticos, nestes casos o diagnóstico da hepatite crônica é feito pela detecção ocasional de uma alteração da transaminase ou de um marcador viral (BENENSON 1995).

A infecção pelo VHB e VHC podem levar ao estado de portador crônico, quadro em que o paciente permanece assintomático, mas pode transmitir o vírus. Essas infecções são importantes fatores de risco para o desenvolvimento de cirrose, e de hepatocarcinoma (SCHAFER e col. 1999).

\subsection{DIAGNÓSTICO LABORATORIAL DAS HEPATITES VIRAIS}

O diagnóstico das hepatites virais requer dois grupos de testes: um para confirmar se os sintomas são decorrentes do processo inflamatório das células hepáticas; e outro para definir o agente etiológico. A maioria desses testes pode ser realizada com uma amostra de soro do paciente colhida na ocasião em que procura o serviço médico com algum sintoma sugestivo de hepatite ou com história de contato com algum caso da doença.

O primeiro grupo é denominado de "provas de função hepática", e inclui os exames utilizados na determinação da atividade das seguintes enzimas séricas: bilirrubinas, alanina aminotransferase, aspartato aminotransferase, fosfatase alcalina e gama-glutamiltransferase. Em caso de lesão das células hepáticas, pode ocorrer a elevação nos níveis de qualquer uma dessas enzimas. As aminotransferases ou transaminases são as mais utilizadas no diagnóstico das hepatites virais, por serem 
marcadores sensíveis de lesões do fígado e por atingirem picos elevados no início dos sintomas.

A alanina aminotransferase (ALT) era conhecida como transaminase glutâmico pirúvica (TGP), e a aspartato aminotransferase (AST) como transaminase glutâmico-oxalacética (TGO). Altos valores destas enzimas sugerem extenso acometimento do parênquima hepático, especialmente nas hepatites agudas, porém valores baixos não excluem o diagnóstico de hepatite. Há descrição de casos em que os indivíduos com níveis normais destas enzimas têm evidência de hepatite aguda na biópsia hepática. Na hepatite benigna, os níveis de ALT são significativamente mais altos do que os de AST, mas em alguns casos mais graves, o inverso pode ser observado (HOLLINGER 1996; HOUGHTON 1996).

A bilirrubina é um pigmento biliar que tem seu metabolismo alterado por uma lesão hepatocelular. A determinação da bilirrubina sérica é outro exame freqüentemente utilizado, o aumento dos seus níveis é observado na fase pré-ictérica das hepatites. Nas hepatites benignas geralmente se normaliza antes das transaminases, nas formas mais graves o inverso é mais comum.

A determinação da etiologia das hepatites virais só pode ser realizada por técnicas sorológicas para detecção dos marcadores virais específicos, que serão descritos a seguir para cada uma das hepatites.

\subsubsection{HEPATITE A}

Ainda que o diagnóstico virológico da infecção pelo VHA possa ser feito pela detecção do RNA do VHA (no soro, nas fezes ou no fígado) ou do antígeno (nas fezes) durante o período de incubação ou no início da fase sintomática da hepatite A, o diagnóstico sorológico é mais prático, menos trabalhoso e amplamente disponível (KOFF 1992). Anticorpos contra o VHA (anti-VHA) podem ser detectados por uma variedade de técnicas sorológicas, incluindo imunomicroscopia eletrônica, fixação de complemento, imunofluorescência, radioimunoensaio e ensaio imunoenzomático (EIE) (GUST 1998). Atualmente, a técnica mais utilizada é o EIE. Estão disponíveis no mercado testes sensíveis e específicos para a detecção do anti-VHA total e do anti-VHA IgM no soro. Testes para detecção de anticorpos na saliva estão em 
desenvolvimento (OBA 2000; KOFF 1998), alguns trabalhos relatam o emprego da saliva em estudos epidemiológicos (BULL e col. 1989; OCHNIO 1997).

Os anticorpos contra o VHA podem ser detectados concomitantemente às manifestações clínicas. Inicialmente, surgem os anticorpos da classe IgM, seguidos pelo aparecimento dos da classe $\operatorname{IgG}$, que são detectáveis durante toda a vida e conferem proteção duradoura contra a infecção.

O diagnóstico sorológico da hepatite aguda é feito pela da pesquisa do antiVHA IgM que pode ser detectado no soro por um período de 10 a 16 semanas, com pico entre a 4a e 6a semana, confirmando a infecção recente pelo VHA. Alguns autores afirmam que este marcador pode permanecer detectável no soro por até 6 meses (KOFF 1992, 1998). A pesquisa do anti-VHA IgG é útil para detecção de infecção prévia pelo VHA e na avaliação da imunidade após a vacinação, sendo o marcador utilizado em levantamentos soroepidemiológicos, em estudos de prevalência (Figura 1).

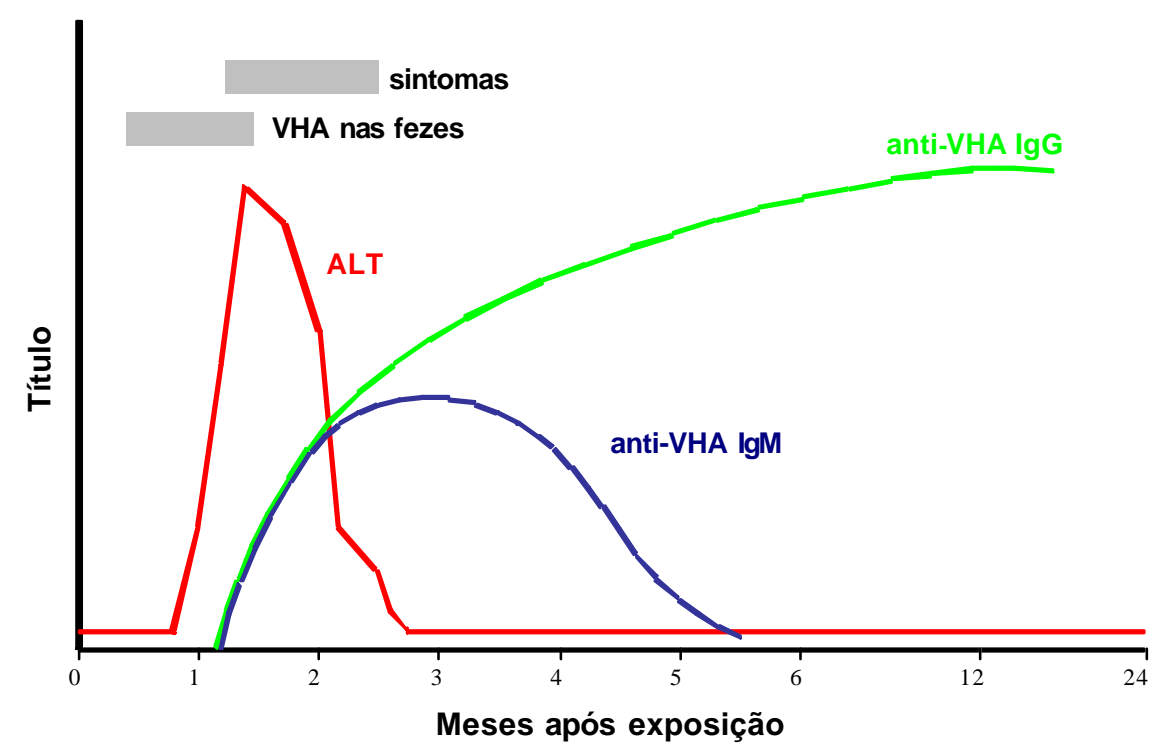

Figura 1 - Representação esquemática dos eventos clínicos e sorológicos na hepatite A aguda

Fonte: CDC 1995, modificado

O RNA do VHA pode ser detectado durante a fase aguda da doença por métodos de amplificação do ácido nucleico. $\mathrm{O}$ seqüenciamento do genoma tem sido 
utilizado para identificar os vírus circulantes. Entretanto, esses métodos são utilizados apenas por alguns laboratórios de pesquisa (CDC 1999).

\subsubsection{HEPATITE B}

A confirmação diagnóstica da hepatite $B$ pode ser realizada por testes sorológicos que buscam identificar os diferentes antígenos do VHB, os anticorpos correspondentes a esses antígenos e o DNA viral. A dinâmica de aparecimento desses marcadores é reflexo da replicação viral e da resposta imune do paciente (Figuras 2 e 3) (DECKER 1998).

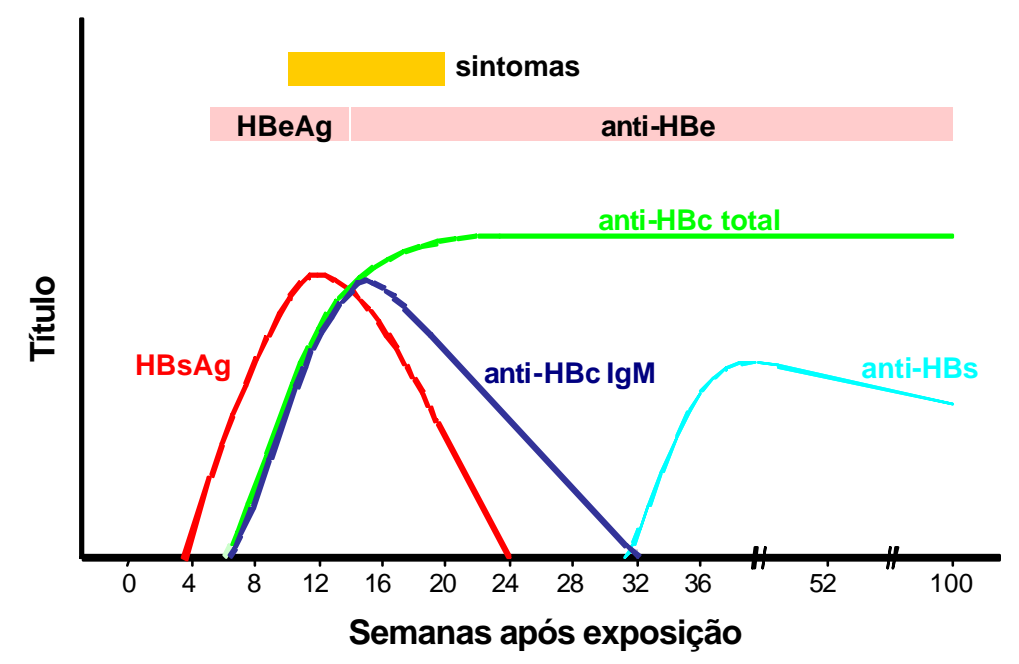

Figura 2 - Representação esquemática dos eventos clínicos e sorológicos na hepatite B aguda

Fonte: CDC 1995, modificado 
Figura 3 - Representação esquemática dos eventos clínicos e sorológicos na hepatite B crônica

Fonte: CDC 1995, modificado

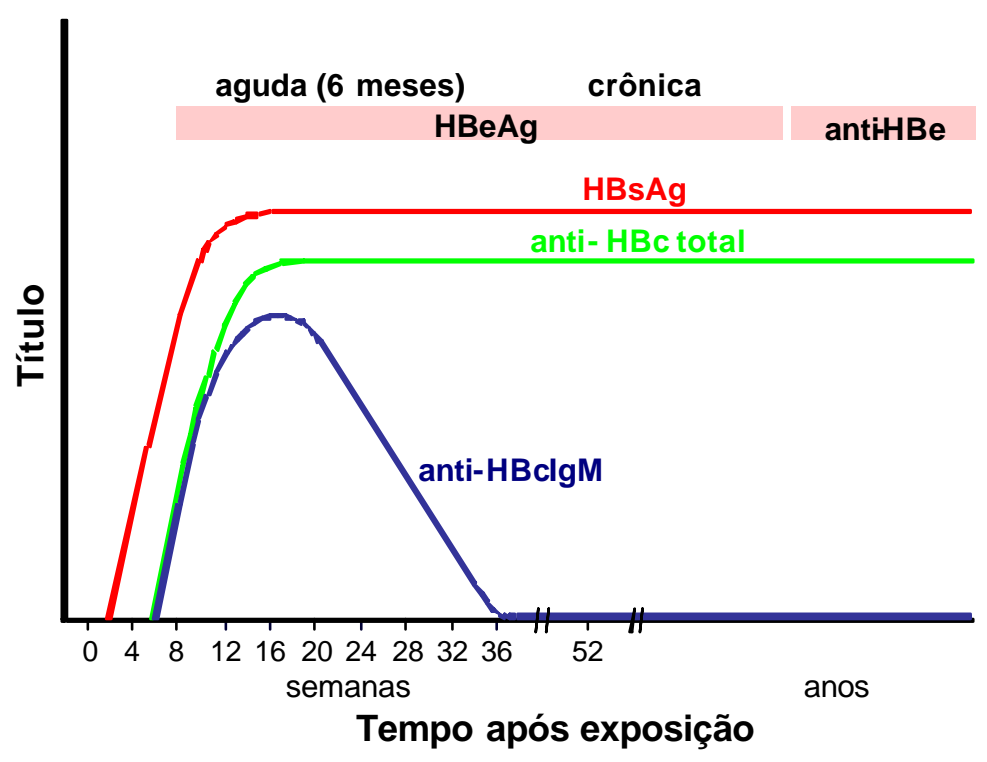

O HBsAg é o primeiro marcador que aparece durante o curso de uma infecção pelo VHB. Na hepatite aguda ele persiste de 3 a 4 meses após a infecção, desaparecendo nos casos de cura. A sua presença por mais de seis meses é indicativo de hepatite crônica (DECKER 1998). O surgimento do anti-HBs varia entre 1 e 10 semanas após o desaparecimento do HBsAg, em geral estes marcadores não são encontrados simultaneamente. O período, após a infecção, em que não se detecta nem um dos dois marcadores é conhecido como janela imunológica. É o único anticorpo neutralizante que confere imunidade ao indivíduo. Em indivíduos vacinados contra hepatite $\mathrm{B}$, é encontrado isoladamente.

$\mathrm{O} \mathrm{HBeAg}$ é o segundo marcador a aparecer e indica intensa replicação viral e a persistência deste marcador por 8 ou 10 semanas após o surgimento dos sintomas pode ser indicativo de evolução para hepatite crônica. Quando presente no soro de portadores crônicos, indica hepatite crônica ativa. Este antígeno só é encontrado na presença de HBsAg, e representa o período de maior infecciosidade. Seu desaparecimento, seguido do desaparecimento do HBsAg é sugestivo de evolução 
para a cura (DECKER 1998). O aparecimento do anti-HBe é um bom prognóstico por indicar baixa replicação viral.

$\mathrm{O}$ anti-HBc IgM é terceiro marcador a aparecer e é um indicador de infecção recente, já o anti-HBc IgG é importante marcador de infecção passada, porém não é um anticorpo neutralizante. $\mathrm{O}$ anti-HBc é o marcador que pode ser detectado na janela imunológica. Portanto, enquanto o anti-HBc IgM representa um importante auxílio diagnóstico na fase aguda da infecção, o anti-HBc IgG é um marcador clínico e epidemiológico desta infecção.

O significado da presença dos diferentes marcadores sorológicos dos indivíduos com hepatite B está representado no quadro 1.

A detecção do DNA do VHB é útil na identificação de variantes genéticas do vírus e na avaliação da resposta ao tratamento da infecção crônica pelo VHB. As técnicas empregadas na detecção do DNA do VHC são a hibridização e a PCR, sendo que a última apresenta sensibilidade maior que a primeira. Recentemente, foi descrita uma terceira técnica, a da reação do DNA ramificado ou branched-DNA (MAHONEY 1999).

Quadro 1 - Infecção pelo VHB: interpretação do quadro sorológico.

\begin{tabular}{|c|cccccc|}
\hline INTERPRETAÇÃ & HBsAg & Anti- & Anti-HBc & Anti- & Anti- & HBeAg \\
\hline Fase de incubação & + & - & - & - & - & - \\
\hline \multirow{2}{*}{ Fase aguda } & + & + & + & - & - & + \\
& + & + & + & - & - & - \\
\hline Final da fase & + & + & - & - & - & + \\
aguda ou & + & + & - & - & + & - \\
Hepatite crônica & + & + & - & - & - & - \\
\hline Fase convalescente & - & + & + & - & - & - \\
\hline & - & + & - & - & - & - \\
Infecção passada & - & + & - & - & + & - \\
& - & + & - & + & + & - \\
& - & + & - & + & - & - \\
\hline Resposta vacinal & - & - & - & + & - & - \\
\hline
\end{tabular}

Fonte: HOLLINGER 1996, MAHONEY 1999, modificado 


\subsubsection{HEPATITE C}

Inicialmente, o diagnóstico sorológico da hepatite $\mathrm{C}$ pode ser realizado pela pesquisa de anticorpos anti-VHC, utilizando testes comerciais de EIE, que empregam antígenos virais recombinantes. A metodologia utilizada para o desenvolvimento desses ensaios está baseada na organização genômica do VHC. O genoma possui vários segmentos codificadores de proteínas (antígenos) estruturais e não-estruturais que podem desencadear a produção de anticorpos. Os primeiros testes, denominados de testes de primeira geração, empregavam apenas uma proteína não-estrutural (c100-3). A utilidade clínica era limitada, devido à demora no surgimento dos anticorpos contra essa proteína, em média 24 semanas, porém representou um grande avanço na prevenção da infecção pós-transfusional não-A, não-B. Para aumentar a sensibilidade do método e diminuir o tempo necessário para a detecção dos anticorpos após a infecção, foram desenvolvidos testes que incluem uma combinação de antígenos. Os testes de segunda geração detectam anticorpos contra os antígenos c22, c33, c100 e 5-1-1, o tempo de soroconversão diminuiu para, em média, 15 semanas. Os testes de terceira geração diferem dos de segunda por incluírem antígenos da região NS5 (PINHO e col. 1995; LOK e GUNARATNAM 1997).

Apesar dessas modificações para aumentar a sensibilidade, os ensaios imunoenzimáticos ainda são questionados pelos resultados falso-positivos. A especificidade pode ser aumentada com o emprego de um teste complementar do tipo immunoblot recombinante, no qual os antígenos do VHC são individualizados em uma fita de nitrocelulose (SANTOS e col. 1999). Em grupos de alto risco, tais como os indivíduos com doença clínica do fígado e/ou níveis de ALT elevados, a taxa de concordância entre os dois testes geralmente é alta. Entretanto, em grupos de baixo risco, tais como os doadores de sangue, muitos resultados positivos de EIE não são confirmados (HOUGHTON 1996; DI BISCEGLIE 1998). Nesses casos, torna-se necessária a detecção da viremia para estabelecer o diagnóstico da hepatite $\mathrm{C}$.

O PCR é considerado a técnica "padrão-ouro" no diagnóstico do VHC, pois é capaz de detectar pequenas quantidades de vírus no soro, durante as primeiras semanas após a exposição ao vírus. O PCR pode ser utilizado para pesquisa qualitativa do RNA ou para estimar a quantidade presente no soro (carga viral), útil 
na avaliação da resposta ao tratamento da hepatite crônica. O Quadro 2 mostra como o EIE, RIBA e o PCR podem ser utilizados no diagnóstico da hepatite C.

Muito recentemente surgiu a possibilidade de detecção de antígenos circulantes do VHC, por método de ELISA modificado, permitindo a identificação de infecção presente, e não apenas de contato prévio ou atual, como oferecido pela detecção de anticorpos (TANAKA e col. 2000).

Quadro 2 - Interpretação dos testes diagnósticos da hepatite C

\begin{tabular}{|c|cccc|}
\hline INTERPRETAÇÃO & EIE & RIBA & $\begin{array}{c}\text { VHC } \\
\text { RNA }\end{array}$ & ALT \\
\hline Hepatite C crônica & positivo & positivo & positivo & elevada \\
Portador do VHC & positivo & positivo & positivo & normal \\
Cura da infecção pelo VHC & positivo & positivo & negativo & normal \\
Anti-VHC falso-positivo & positivo & negativo & negativo & normal \\
\hline
\end{tabular}

Fonte: DI BISCEGLIE 1998, modificado.

Ao contrário do que acontece nas outras hepatites virais, a diferenciação entre a forma aguda e crônica não se faz pela detecção dos anticorpos do tipo $\operatorname{IgM}$, já que esses podem não aparecer, aparecer tardiamente ou persistir com a infecção crônica (Figura 4).

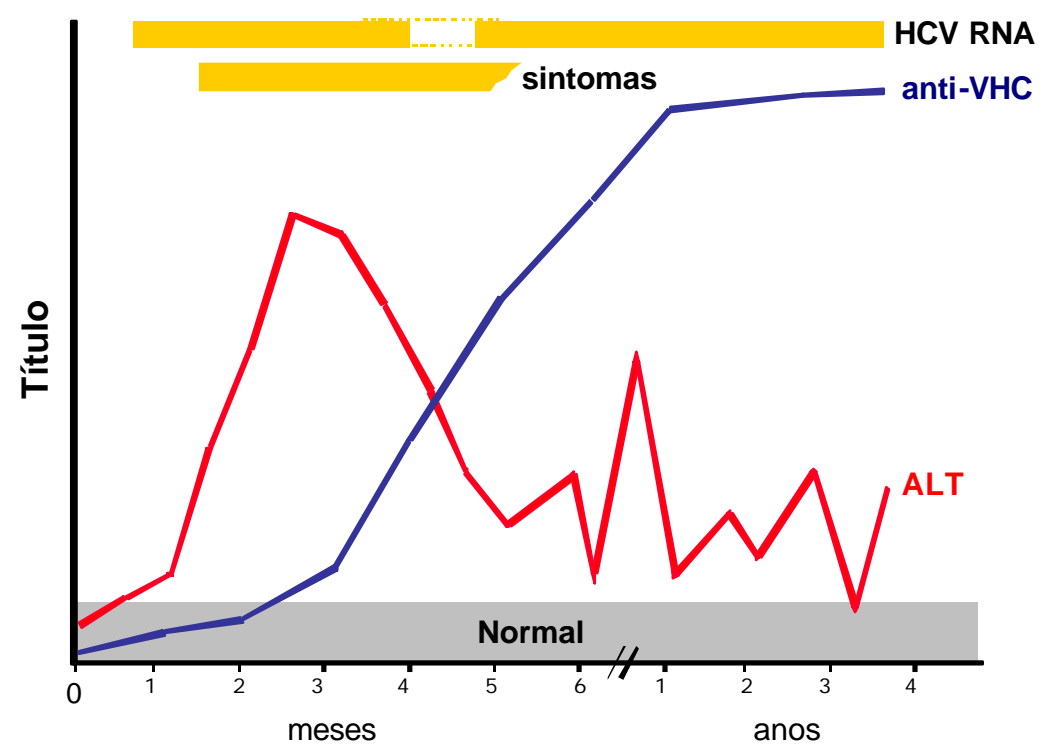

Tempo após exposição 
Figura 4 - Representação esquemática dos eventos clínicos e sorológicos na hepatite C crônica

Fonte: CDC 1995, modificado

A alta diversidade genética do VHC acarreta uma série de implicações no diagnóstico, patogênese, tratamento e desenvolvimento de vacinas. As técnicas de genotipagem permitem reconhecer os diferentes tipos e subtipos do vírus. Tendo em vista que cada tipo do VHC responde de forma diferente ao tratamento, a genotipagem desempenha papel importante na definição da terapia antiviral a ser utilizada no tratamento da hepatite C crônica e de sua duração (STUYVER 1996; CDC 1998).

\subsubsection{HEPATITE D}

A infecção pelo VHD só ocorre em associação com a infecção pelo VHB. O, o curso sorológico da hepatite D depende da forma como essa infecção ocorreu: se simultânea (co-infecção) ou posterior (superinfecção) à infecção pelo VHB. É importante o diagnóstico diferencial entre essas duas formas, porque elas apresentam prognósticos diferentes. A superinfecção é mais grave, ocasionando formas fulminantes de hepatite, evoluindo para hepatite crônica em cerca de $70 \%$ dos casos (PURCELL e GERIN 1996; FONSECA 1997;TAYLOR 1999).

O diagnóstico da hepatite $\mathrm{D}$ é baseado em testes sorológicos, os mais utilizados são os ensaios imunoenzimáticos (ELISA) para pesquisa do anti-HD IgG, do anti-HD IgM e do HDAg. A pesquisa do RNA do VHD, por PCR ou por técnicas de hibridização molecular têm importância fundamental no diagnóstico da hepatite crônica (FONSECA 1997). Os diversos perfis da infecção pelo VHB e VHD são identificados no quadro abaixo: 
Quadro 3 - Diferentes perfis sorológicos relativos à infecção pelo VHB e VHD

\begin{tabular}{|c|ccc|}
\hline \multirow{2}{*}{ Marcador } & \multicolumn{2}{|c|}{ HEPATITE D AGUDA } & Hepatite D crônica \\
\hline HBsAg & positivo & positivo & positivo \\
HDAg & transitório & transitório & positivo \\
Anti-HDV total & transitório & títulos elevados & títulos altos \\
Anti-HDV IgM & transitório & títulos elevados & positivo \\
HDV RNA & transitório & transitório & positivo \\
Anti-HBc IgM & positivo & negativo & negativo \\
\hline
\end{tabular}

Fonte: FONSECA 1997; DI BISCEGLIE 1998

$\mathrm{Na}$ co-infecção todos os marcadores de replicação viral desaparecem precocemente, e o anticorpos do tipo IgM e mesmo o tipo IgG desaparecem em meses ou anos após a cura. Ao contrário, do que ocorre na super-infecção que geralmente resulta em uma infecção persistente. O curso típico da hepatite D é ilustrado nas figuras 5 e 6.

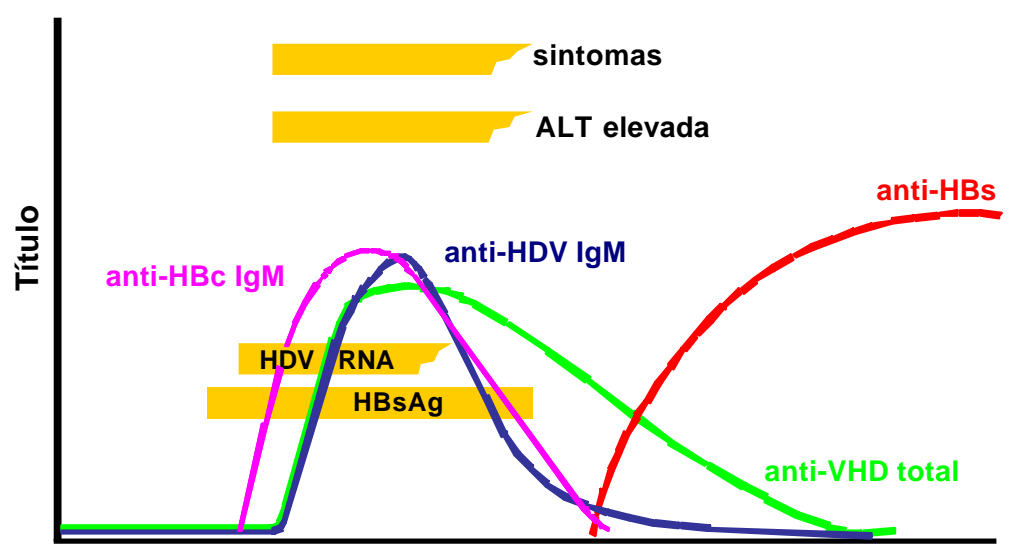

Tempo após a exposição

Figura 5 - Representação esquemática dos eventos clínicos e sorológicos na hepatite D - Co-infecção

Fonte: CDC 1995, modificado 


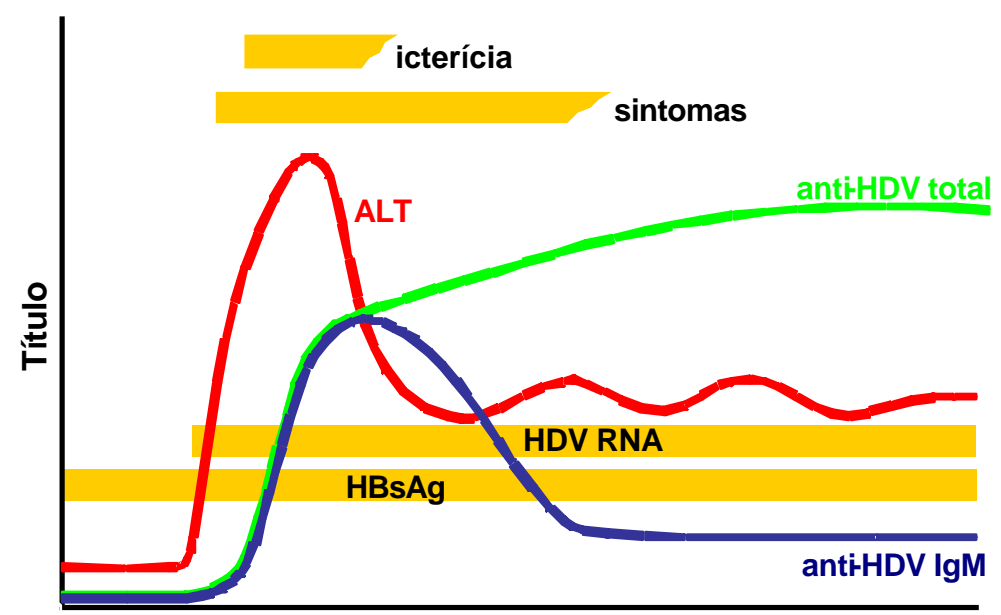

Tempoapós exposição

Figura 6 - Representação esquemática dos eventos clínicos e sorológicos na hepatite D - Superinfecção

Fonte: CDC 1995, modificado

A confirmação da forma crônica da hepatite D é baseada na detecção de antiHD, IgM ou IgG, em altos títulos (maiores do que 1:100.000) e na presença do HDAg no tecido hepático. A pesquisa desse antígeno é realizada por técnica de imunoperoxidase ou imunofluorescência (PURCELL e GERIN 1996; FONSECA 1997).

\subsubsection{HEPATITE E}

Até recentemente, os métodos utilizados para o diagnóstico eram a imunomicroscopia eletrônica, para identificação do vírus nas fezes, e os testes imuno-histoquímicos, para detecção dos antígenos do VHE na superfície dos hepatócitos. Os dois métodos são trabalhosos, têm baixa sensibilidade e estão disponíveis em poucos centros de pesquisas. A elucidação da seqüência genética do VHE, por meio de técnicas de clonagem e seqüenciamento, permitiu desenvolvimento de técnicas de melhor desempenho, como a PCR e os ensaios imunoenzimáticos (PANDA e JAMEEL 1997).

A PCR é uma técnica sensível e específica que pode detectar o RNA viral na bile, sangue, fezes e fígado, desempenhando papel importante no entendimento dos 
padrões da doença e dos aspectos moleculares do VHE. Tem sido utilizado em estudos epidemiológicos, para caracterizar vírus de diferentes regiões geográficas. Porém, é basicamente um instrumento de pesquisa caro e trabalhoso, o que dificulta sua utilização no diagnóstico de rotina (PANDA e JAMEEL 1997; YARBOUGH 1999).

O desenvolvimento dos ensaios imunoenzimáticos para detecção de anticorpos anti-VHE IgM e IgG possibilitou um grande avanço na compreensão da epidemiologia e do curso clínico da hepatite E. Esses testes podem ser produzidos com antígenos recombinantes do VHE ou peptídeos sintéticos. Os primeiros parecem ser mais sensíveis na captura de anticorpos e são utilizados nas técnicas de EIE e Western blot. Até o momento, os ensaios imunoenzimáticos são os testes mais convenientes, baratos e adequados para o diagnóstico de rotina assim como para levantamentos soroepidemiológicos (PANDA e JAMEEL 1997; HARRISON 1999).

Anticorpos anti-VHE IgM alcançam níveis mais elevados durante as primeiras 4 semanas depois do aparecimento dos sintomas, porém os títulos diminuem entre 10 a 12 semanas depois da fase aguda (YARBOUGH 1999). Os anticorpos IgG atingem altos níveis na fase aguda da doença, entretanto, não há consenso quanto à persistência desses níveis após a fase de convalescença (Figura 7) (PURCELL 1996; HARRISON 1999; YARBOUGH 1999). Estudo realizado por Bryan e col, durante uma epidemia no Paquistão, demonstrou que o anti-VHE IgG atinge título máximo 2 semanas após o início dos sintomas (1:5000), permanecendo detectável no soro até 20 meses, com títulos inferiores ao da fase aguda (1:100) (BRYAN e col 1994). 


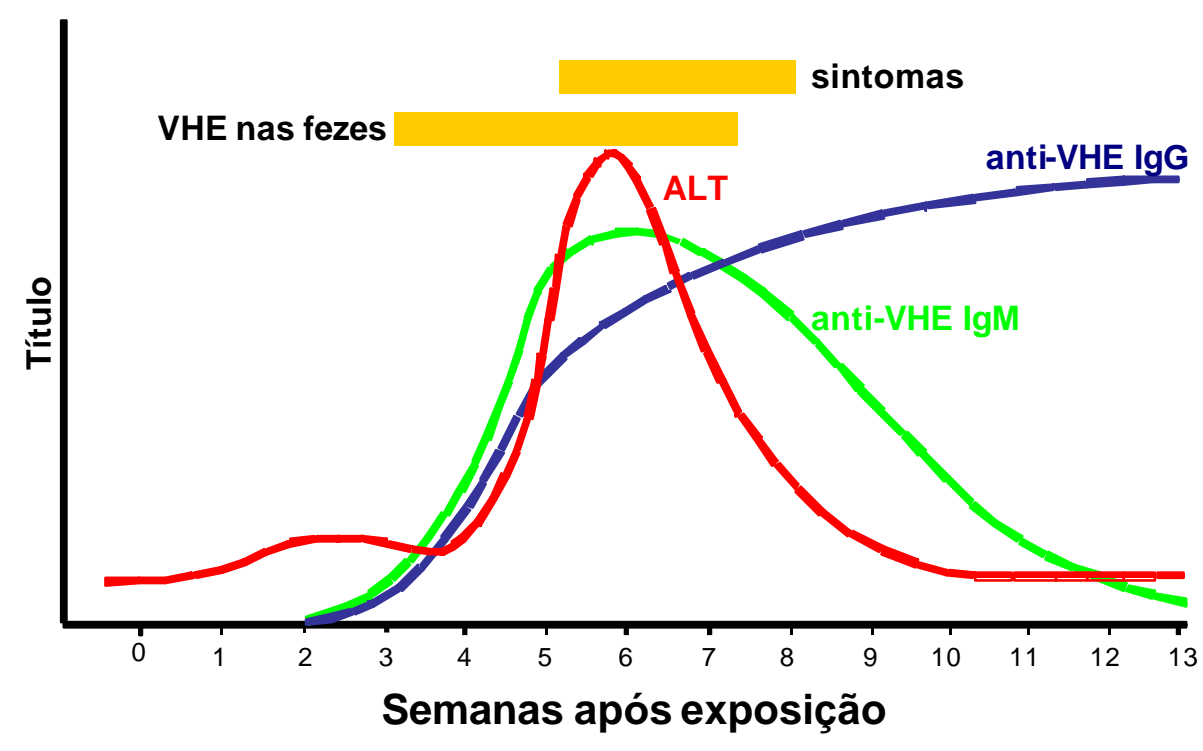

Figura 7 - Representação esquemática dos eventos clínicos e sorológicos na hepatite E aguda.

Fonte: CDC 1995, modificado 


\subsection{EPIDEMIOLOGIA DAS HEPATITES VIRAIS}

\subsubsection{HEPATITE A}

O período de incubação do vírus da hepatite A é de 15 a 45 dias, com média de 30 dias (CARRILHO e SILVA 1995, ZACHOVAL e DEINHARDT 1998; CDC 1999). O período de transmissibilidade inicia-se 2 a 3 semanas antes do inicio dos sintomas e estende-se até 8 dias após o aparecimento da icterícia. Investigações de epidemias de hepatite A demonstraram que o período de máxima infectividade é aproximadamente uma semana antes do aparecimento da icterícia ou da elevação das enzimas hepáticas, quando a concentração do vírus nas fezes é mais alta. Durante a fase de convalescença, não se detecta o agente nas fezes (CATTON e LOCARNINI 1998).

A resistência do vírus da hepatite A no ambiente é relativamente alta. Alguns estudos demonstraram a capacidade infectante do VHA em água e solos, contaminados experimentalmente, após 3 meses a $25^{\circ} \mathrm{C}$, em superfícies inertes até 1

mês a $25^{\circ} \mathrm{C}$ e em biscoitos após 30 dias a $21^{\circ} \mathrm{C}$. Apresenta certa estabilidade a temperatura: permanece viável por vários anos a $-70^{\circ} \mathrm{C}$ e até 1 hora em temperatura entre $37^{\circ}$ e $60^{\circ} \mathrm{C}$. É inativado pela fervura a $100^{\circ} \mathrm{C}$ por 1 minuto. É resistente aos desinfetantes de superfície mais comuns, como o éter e os detergentes não iônicos, porém perde a infectividade quando exposto ao formaldeído $(0.25 \%)$ por 72 horas, ao cloro $(1 \mathrm{mg} / \mathrm{ml})$ por 30 minutos e à radiação ultravioleta. Outra forma de inativar o VHA é pelo aquecimento com tampão-fosfato (PBS) a $70^{\circ} \mathrm{C}$ por 30 minutos, ou $80^{\circ} \mathrm{C}$ por 5 segundos e a $85^{\circ} \mathrm{C}$ a inativação é imediata. (PERRENOUD 1995; CATTON e LOCARNINI 1998; CDC 1999)

\section{Transmissão}

A via de propagação mais importante do VHA é a fecal-oral, podendo ocorrer, por ex., a partir indivíduos com mãos contaminadas da fonte de infecção para indivíduo suscetível, pela ingestão de água ou alimentos contaminados (CATTON e LOCARNINI 1998; CDC 1999). 
A disseminação pessoa-a-pessoa, via fecal-oral, é a forma de transmissão mais importante da hepatite A, e explica os surtos que ocorrem com freqüência em creches, em instituições para deficientes mentais, e ocasionalmente em hospitais (ZACHOVAL e DEINHARDT 1998; CATTON e LOCARNINI 1998).

Em regiões onde as condições de saneamento básico e de habitação são precárias, a prevalência dos anticorpos anti-VHA é maior. A água de abastecimento público, quando não tratada, constitui um dos mais importantes veículos de propagação do vírus (HOLLINGER e TICEHURST 1996, CATTON e LOCARNINI 1998).

A transmissão parenteral é teoricamente possível, porém o curto período de viremia (7 a 12 dias) e a baixa concentração de vírus no sangue explicam porque são raros os casos de hepatite $\mathrm{A}$ relacionados à transfusão de sangue (HOLLINGER e TICEHURST 1996; CDC 1999).

Outra possível fonte de infecção é a manipulação de alimentos por pessoas infectadas pelo VHA que disseminam o vírus durante o período de incubação. Em 1974, foi descrita uma epidemia com 133 casos entre recrutas navais de San Diego que consumiram salada e suco preparados por um indivíduo infectado. Em 1991, 230 casos ocorreram entre pessoas que consumiram sanduíches de duas lojas de Milwaukee preparados pela mesma pessoa infectada pelo VHA (CATTON e LOCARNINI 1998).

Mariscos são outra fonte de infecção bastante freqüente, quando capturados em água contaminada pelo VHA. Muitas vezes a temperatura utilizada para a preparação dos mariscos não é suficientemente alta para destruir o vírus. Em dezembro de 1988, em Shangai, teve inicio uma epidemia de grandes proporções com o registro de 20.000 casos de hepatite A; em meados de janeiro esse número subiu para 300.000 casos, sendo que o consumo de marisco cru foi associado a $90 \%$ dos casos. Posteriormente o VHA e seu RNA foram detectados nesse moluscos (HOLLINGER e TICEHURST 1996; CATTON e LOCARNINI 1998; ZACHOVAL e DEINHARDT 1998).

A transmissão perinatal foi estudada em alguns casos isolados de hepatite A em recém-nascidos. O VHA não foi detectado no cordão umbilical, mas foi no soro e nas fezes do recém-nascido. Conclui-se que a transmissão do VHA para a criança 
ocorre via canal de parto, contaminado com sangue ou fezes da mãe infectada pelo vírus (CATTON e LOCARNINI 1998). Por outro lado quando a mãe é imune, o antiVHA ultrapassa a barreira placentária, observando-se títulos decrescentes (CARRILHO e SILVA 1995).

O VHA foi encontrado em secreção respiratória, na saliva e na urina, mas não há provas convincentes de que a transmissão ocorra por essas vias (CARRILHO e SILVA 1995).

O contato oral-anal, freqüente entre os homossexuais masculinos, propicia a disseminação do vírus, e tem sido relacionado com epidemias de hepatite A nos Estados Unidos, Canadá, Europa e Austrália (CDC 1999).

\section{Ocorrência}

Não há diferença na prevalência de anti-VHA entre homens e mulheres ou entre pessoas de raças diferentes, numa mesma comunidade desde que comparemos indivíduos do mesmo nível sócio-econômico (ZACHOVAL e DEINHARDT 1998).

A doença pode surgir em qualquer idade. Em crianças, a freqüência da doença assintomática e o período de eliminação do vírus nas fezes são maior que nos adultos. Esses fatores aliados a relativa falta de cuidados com higiene nesse grupo etário, conferem às crianças um papel importante na epidemiologia da hepatite A.

A hepatite A tem uma distribuição universal porém desigual entre algumas regiões geográficas e grupos populacionais. As melhorias nas condições de saneamento, habitação e sócio-econômicas estão modificando o padrão de transmissão da doença. Com base nas diferenças desses padrões, o mundo tem sido dividido em três áreas de prevalência (Figura 8), esses padrões podem variar em diferentes comunidade de um mesmo país (GUST 1992; HOLLINGER e TICEHURST 1996; CATTON e LOCARNINI 1998; CDC 1999).

As áreas de alta prevalência são encontradas nos países em desenvolvimento, particularmente nos países tropicais nos quais VHA pode ser hiperendêmico. A exposição ao vírus antes dos 10 anos de idade tende a ser universal, e a soroprevalência entre adultos aproxima-se de $100 \%$.

Nas áreas de prevalência intermediária, ocorre um segundo padrão de prevalência, típico de países desenvolvidos. A exposição ao vírus é pouco freqüente 
entre as crianças, e a prevalência aumenta lentamente entre os adultos jovens, atingindo níveis médios e altos nas faixas etárias mais elevadas. $\mathrm{O}$ terceiro padrão de prevalência ocorre nos países onde a hepatite A não é endêmica. A prevalência é alta em pessoas acima de 20 anos, mas é praticamente nula entre crianças e adolescentes, entretanto quando o vírus é introduzido na comunidade, infecta um grande número de suscetíveis, provocando surtos da infecção. 
Figura 8 - Distribuição geográfica da infecção pelo VHA

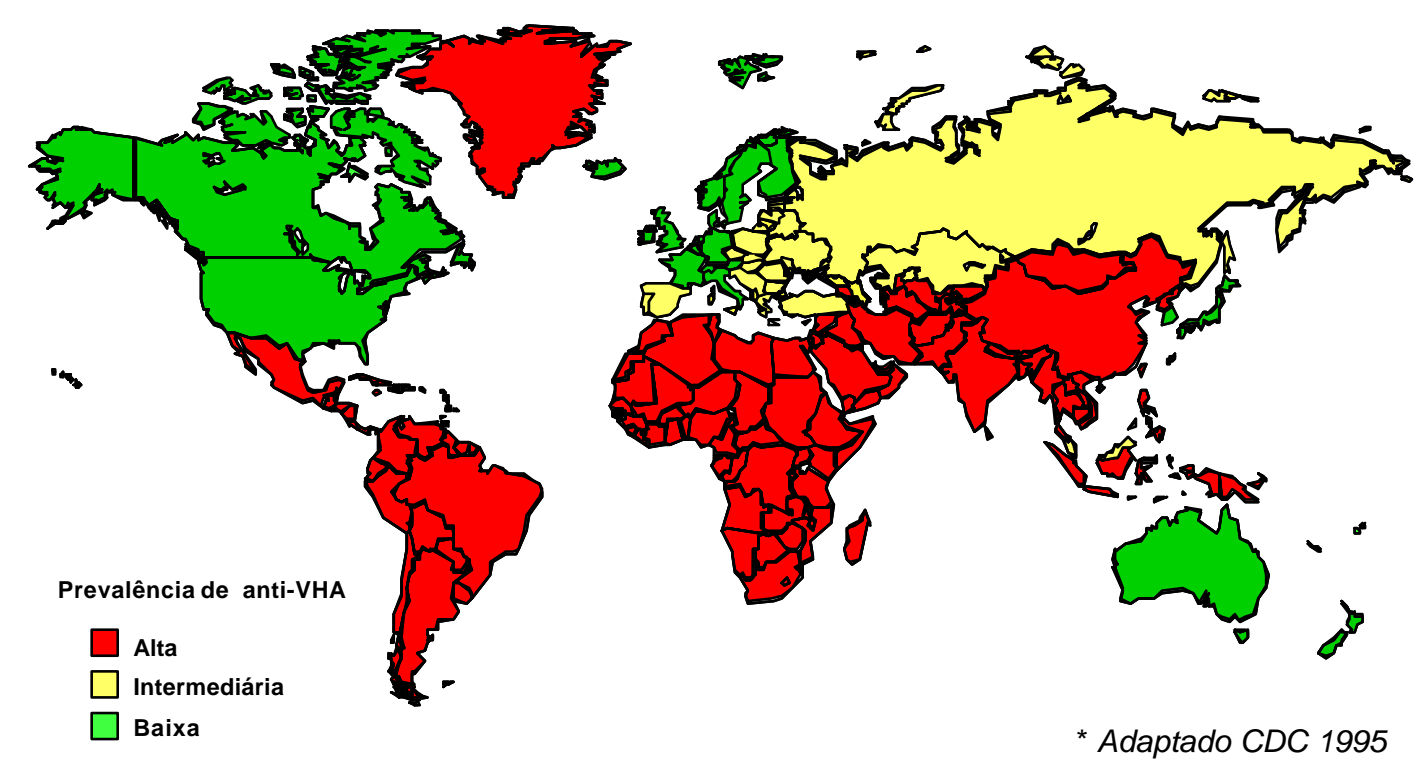

\subsubsection{HEPATITE B}

O período de incubação do vírus da hepatite B é geralmente de 40 a 180 dias com média de 60 a 90 dias, podendo esta variação estar relacionada em parte à quantidade do inóculo e ao modo de transmissão (BENENSON 1995; HOLLINGER 1996). O período de infectividade pode ser de várias semanas antes do inicio dos primeiros sintomas até o final da fase aguda e, pode prolongar-se por vários anos, dependendo da replicação do vírus durante o estado de portador (BENENSON 1995).

O VHB resiste até uma semana em superfície seca. É estável em temperaturas próximas de $30^{\circ} \mathrm{C}$ por pelo menos 6 meses e $-20^{\circ} \mathrm{C}$ por 15 anos. $\mathrm{O}$ vírus mantém a capacidade infectante após a exposição ao éter, ao ácido ( $\mathrm{pH}$ 2,4 por 6 horas) e ao calor $\left(98^{\circ} \mathrm{C}\right.$ por 1 minuto, $60^{\circ} \mathrm{C}$ por 10 horas). $\mathrm{O}$ soro perde a infectividade quando sujeito à fervura por 2 minutos, ao calor seco $\left(160^{\circ} \mathrm{C}\right.$ por 1 hora) ou autoclavado a $121^{\circ} \mathrm{C}$ por 20 minutos. $\mathrm{O} \mathrm{VHB}$, em plasma humano seco, é inativado à temperatura ambiente por 10 minutos, pelo hipoclorito de sódio (500 mg/L), ácido isopropil a 
$70 \%$, glutaraldeído a $0,125 \%$ associado a fenol a 0,44, glutaraldeído $2 \%$ em pH 8,6 e iodo (75 mg/L) (PERRENOUD 1995, HOLLINGER 1996).

\section{Transmissão}

A via de transmissão do VHB mais importante é a parenteral. O sangue contaminado, entrando em contato com mucosas ou lesões de pele, também podem transmitir o VHB. Vêm sendo assinalada a transmissão ocasional, percutânea ou por mucosa, decorrente do uso comum de escovas de dentes ou aparelhos de barbear. As agulhas, e outros instrumento intravenosos contaminados são veículos importantes (BENENSON 1995).

O mecanismo de infecção pré-natal é discutido. A infecção intra-útero do feto pelo VHB é pouco freqüente. A infecção produz-se provavelmente durante ou após o parto. Existem na realidade dois tipos de infecção: a pré-natal, que pode ser definida como aquela que ocorre em qualquer tempo desde o início até o fim do parto e a pósnatal, quando surge após o nascimento da criança. Portanto a transmissão pré-natal pode ser tanto vertical como horizontal.

Como pode haver HBsAg no sêmen, nas secreções vaginais e no sangue menstrual, é possível que o vírus atravesse as superfícies mucosas expostas. Todos esses fatos podem explicar a maior freqüência da hepatite em familiares de portadores. Em alguns locais as prostitutas parecem constituir-se em importante reservatório do VHB (BENENSON 1995; CARRILHO e SILVA 1995).

A saliva contém HBsAg e pode ser infectante, o que foi comprovado pela inoculação em primatas. Apesar do vírus ter sido encontrado na bile e no suco pancreático, as fezes parecem não constituir uma fonte de infecção. Não foram relatadas epidemias de hepatite B associadas ao consumo de água ou alimentos contaminados. Parece haver fatores no trato gastrointestinal que destroem o VHB (CARRILHO e SILVA 1995). 


\section{Ocorrência}

Certos grupos populacionais constituem-se de alto risco para a infecção pelo o VHB, entre eles: trabalhadores da área médica, pacientes em hemodiálise, hemofílicos, deficientes mentais, homossexuais masculinos, prostitutas, presidiários, toxicômanos, familiares de portadores crônicos do VHB.

A hepatite B é uma doença de distribuição universal. A prevalência do VHB e os padrões de transmissão variam enormemente nas diferente partes do mundo. Em

função dessas características, as distintas regiões do mundo são divididas em áreas de alta endemicidade, endemicidade intermediária e baixa endemicidade (Figura 9) (MARGOLIS e col. 1991; EVANS e LONDON 1998; MAHONEY 1999).

Em áreas de baixa endemicidade, a prevalência de portadores crônicos é menos de $2 \%$. O risco de infecção durante a vida é $20 \%$. A transmissão ocorre principalmente em adultos jovens com estilo de vida e comportamento que os colocam dentro do grupo de risco, A importância da transmissão parenteral varia em função do nível de prevalência. São usuários de drogas endovenosas, homossexuais masculinos, pessoas que tem contato heterossexual com várias pessoas, contatos domiciliares de portadores crônicos, hemofílicos, hemodialisados, pessoas com exposição ocupacional a sangue e fluídos corpóreos e pessoas institucionalizadas com distúrbios mentais. Dentro dessas áreas são encontrados grupos étnicos com taxas de infecção pelo VHB maiores que na população geral, e cujos padrões de transmissão são semelhantes aqueles encontrados nas áreas de média ou alta endemicidade, é o caso da população de Esquimós no Alasca e no Canadá, os Maoris na Nova Zelândia. São regiões de baixa endemicidade para a infecção pelo VHB, a América do Norte, a Europa Ocidental, a Austrália, a Nova Zelândia e o sudeste da América do Sul

Em áreas de endemicidade intermediária, a prevalência de portadores crônicos varia de $2 \%$ a $7 \%$ e de 20 a 50\% da população tem evidência sorológica de infecção passada. O risco de adquirir infecção durante a vida varia entre 20 e $60 \%$. A transmissão ocorre em todos os grupos (recém-nascidos, crianças e adulto). Ainda que os recém-nascidos sejam responsáveis pela manutenção das altas taxas de infecção crônica, as taxas mais altas de infecção estão provavelmente entre as 
crianças mais velhas, adolescentes e adultos mais jovens. Ocorrem grande variação na prevalência da infecção nessas áreas , e fatores raciais e sócio-econômicos podem explicar as diferenças no risco da infecção. Ocorre na Índia, em parte do oriente Médio, Ásia Ocidental, Japão, União Soviética, Europa oriental e sul da Europa. Em áreas de alta endemicidade, o risco de infecção pelo VHB é maior que $60 \%$ e a maioria das infecções ocorrem no nascimento ou precocemente na infância. Nessas áreas são observados dois tipos de transmissão do vírus. Na Ásia (exceto Japão e Índia), a infecção perinatal é responsável por pelo menos $25 \%$ dos casos de infeção crônica na população adulta. Entre 5 e 12\% das parturiente são HBsAg positivo, e 30 a $50 \%$ dessas mulheres tem altos níveis antígeno $e$ (HBeAg) ou o DNA do VHB. Esta positividade alta para o $\mathrm{HBeAg}$ é relacionada a um risco mais alto de transmissão, resultando em taxas de infecção perinatal entre 70 e 90\%. Em outra áreas de alta endemicidade, tais como África, Oriente Médio, a infecção perinatal responde por uma pequena proporção das infecções crônicas, porque menos de $20 \%$ das mães $\mathrm{HBsAg}$ positivas também são $\mathrm{HBeAg}$ positivas. Todas as crianças dessas populações têm risco muito grande de adquirir infecção crônica antes dos 5 anos. A transmissão do VHB continua a ocorrer dentro da família, principalmente de mães e irmãos, entretanto outros membros da família infectados cronicamente também podem ser uma fonte de infecção. Nessas áreas a taxa de portadores crônicos varia entre 8 e $25 \%$ e a prevalência de anti-HBs de 60 a $85 \%$. 


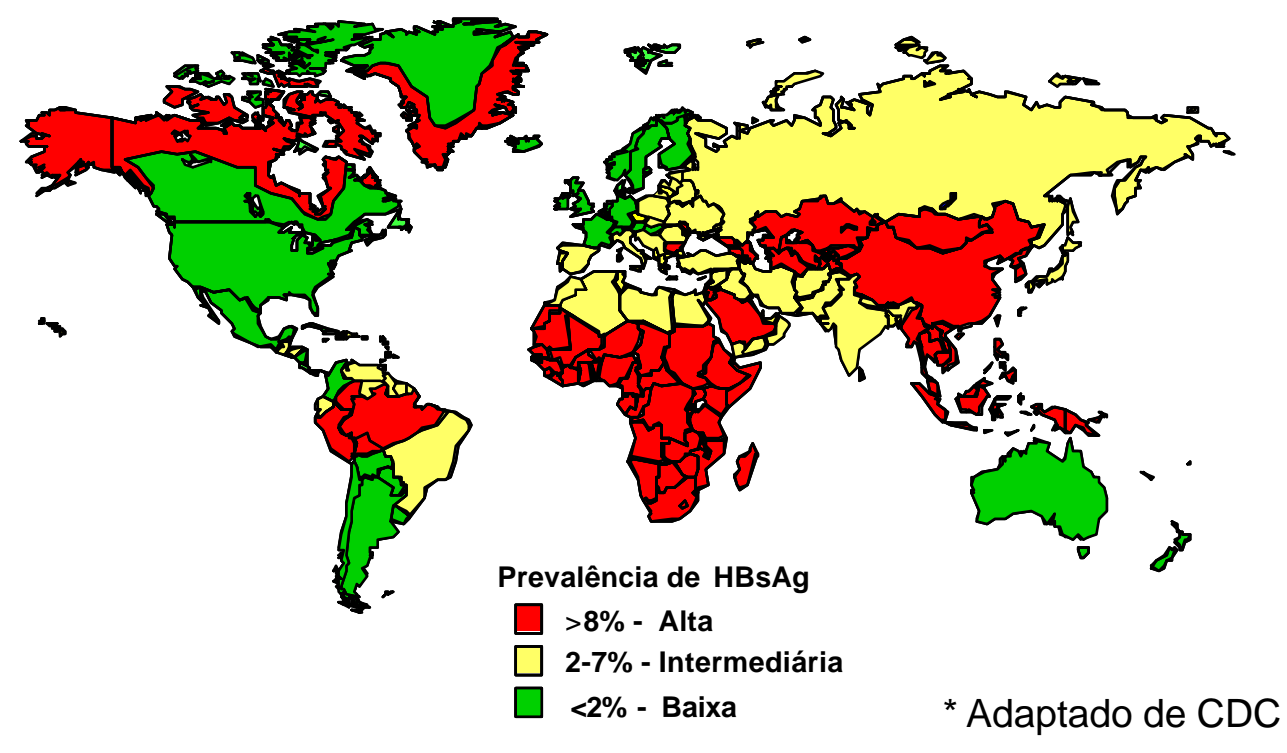

Figura 9 - Distribuição geográfica da infecção pelo VHB

\subsubsection{Hepatite C}

O período de incubação da hepatite $C$ pode durar, em média de 6 a 8 semanas, embora possa se estender por vários meses (BENENSON 1995; CDC 1998). O período de transmissibilidade pode variar de uma a várias semanas antes do inicio dos sintomas, mas pode persistir indefinidamente (BENENSON 1995).

A resistência do vírus da hepatite $\mathrm{C}$ a agentes químicos e físicos não foi tão estudada quanto a dos vírus A e B. Não há indícios que o VHC seja mais resistente a esses agentes do que ou outros vírus (PERRENOUD 1995).

\section{Transmissão}

O modo de transmissão parece ser um fator que influencia no curso da doença porque tem sido sugerido que casos pós-transfusionais evoluem mais severamente que os de transmissão pelo uso de drogas endovenosas, o que pode estar relacionado à carga maior do inóculo em infecções pós-transfusionais (HOUGHTON 1996) 
Até a introdução dos testes de triagem para anti-VHC em doadores de sangue, era tida como a principal causa de hepatite pós-transfusional (CDC 1998)

O papel da transmissão sexual é controverso. Estudos têm encontrado poucas evidências dessa forma de transmissão. Em parceiros sexuais de hemofílicos antiVHC positivos, não tem sido observada positividade para tal marcador. Este marcador não tem sido observado em cônjuge ou parceiros sexuais de pacientes com hepatite $\mathrm{C}$ pós-transfusional. Resumindo existe alguma evidência para a transmissão sexual, mas parece ser pouco freqüente (CARRILHO e SILVA 1995; CDC 1998).

O risco de transmissão vertical perinatal é pouco conhecido, tendo sido descrito com freqüência em mães com transaminase elevadas e/ou por HIV. No Japão, observou-se a transmissão da hepatite C de mãe para filho em 10\% dos casos, estando o risco relacionado com o título do RNA-VHC da mãe. A ausência de RNA nas amostras de sangue obtidas do cordão umbililical das crianças que posteriormente se tornam positivas para este marcador não sugere a transmissão intra-uterina. Neste estudo corroborado por outros, estudou-se a transmissão através do leite materno (CARRILHO e SILVA 1995; THOMAS 1999).

A transmissão do VHC por prática homossexual entre indivíduos do sexo masculino também parece ser rara, mas a prevalência do anti-VHC é maior neste grupo do que na população geral, variando de 4 a $16 \%$. Em muitos estudos tem se demonstrado a relação da infecção do HIV e da presença do anti-VHC (CARRILHO e SILVA 1995; CDC 1999).

Casos de hepatite $\mathrm{C}$ têm sido verificados em trabalhadores da área da saúde após exposição acidental com agulhas ou mesmo sem história evidente de exposição. Suspeita-se que a transmissão percutânea inaparente seja responsável por vários episódios nos quais a fonte de infecção é indefinida e que constituem casos esporádicos (CARRILHO e SILVA 1995).

A ausência do RNA-VHC na saliva e no sêmen tem sido relatada por alguns autores e a presença documentada por outros, podendo ser um método de disseminação do VHC entre familiares. Foi constatada a transmissão da hepatite C, após mordedura humana, o que sugere a efetividade da saliva (CARRILHO e SILVA 1995; HOLLINGER 1996). 


\section{Ocorrência}

A hepatite $\mathrm{C}$ tem distribuição universal. A prevalência, em doadores de sangue, varia entre $0.1 \%$ e $2 \%$ na maioria dos países desenvolvidos. Taxas significativamente mais altas têm sido encontradas, com taxas mais altas no Japão, Espanha, Hungria, Arábia Saudita e sudeste da Itália. O Egito apresenta a maior prevalência variando entre 10 e 30\% (Figura 10) (HOUGHTON 1996; DI BISCEGLIE 1998; THOMAS 1999).

A infecção pelo VHC é sem dúvida a causa mais importante das hepatites em hemofílicos, como se pode verificar pela freqüência de anti-VHC e comprovação pelo RIBA (CDC 1998; THOMAS 1999)

A freqüência de anti-VHC em usuários de drogas é extremamente alta variando 48 a $90 \%$. Constituem grupo de risco os hemodialisados e os receptores de transplante renal (CARRILHO e SILVA 1995; CDC 1998). 

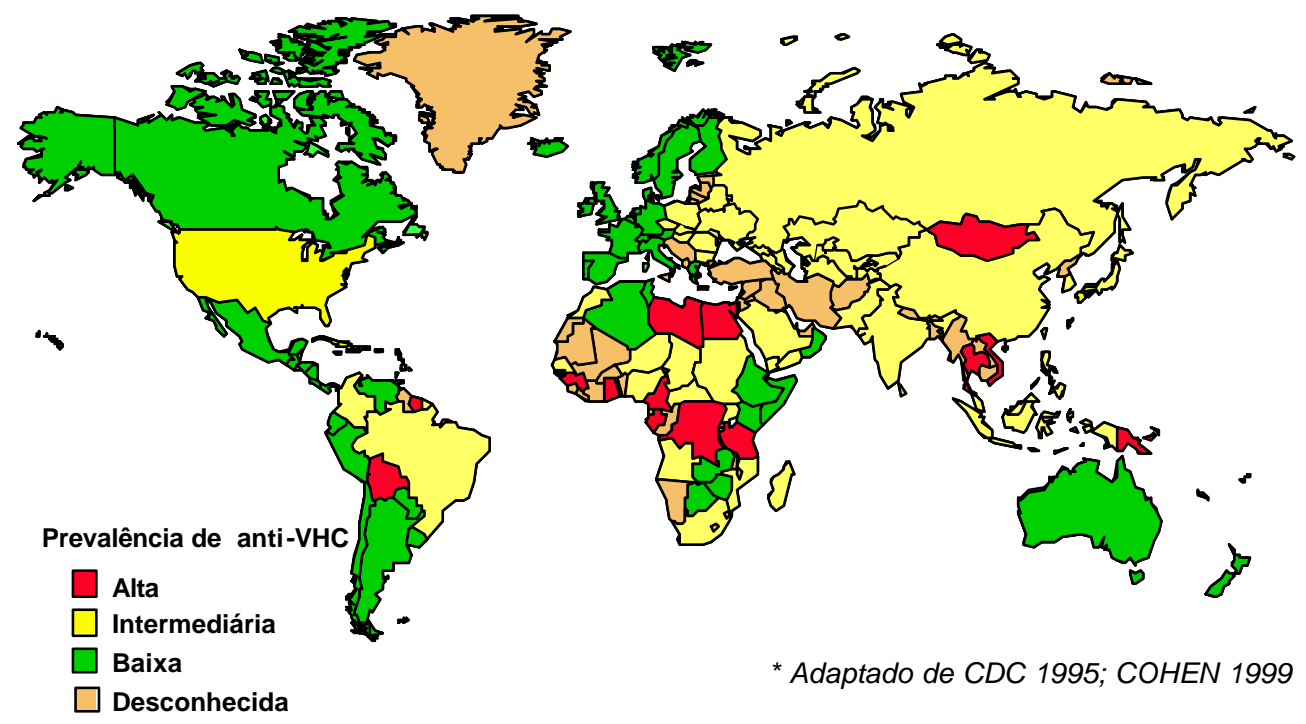

* Adaptado de CDC 1995; COHEN 1999

Figura 10 - Distribuição geográfica da infecção pelo VHC

\subsubsection{HEPATITE D}

O período de incubação em infecção natural no homem ainda não está definido. Em chimpanzés infectados experimentalmente foi de 2 a 10 semanas com média de 35 dias. (PERRENOUD 1995; FONSECA 1997).

A resistência do VHD ao meio ambiente e a desinfetantes ainda não foi bem estabelecida como foi para os vírus da hepatite A e B. Não há indícios que seja mais resistente aos agentes químico e físicos que os outros vírus (PERRENOUD 1995).

\section{Transmissão}

Acredita-se que o vírus da hepatite D tenha mecanismos de transmissão idênticos aos do VHB. Assim, a principal via de transmissão é a parenteral. Os grupos de risco para hepatite $\mathrm{D}$ também seriam os mesmos da hepatite $\mathrm{B}$, dentre esses os usuários de drogas seriam as maiores vítimas da infecção no mundo, com uma prevalência que varia de 17 a 98\% (PURCELL E GERIN 1996; FONSECA 1997). 
Ocorre em todos os grupos etários. Na Amazônia brasileira, tem-se observado maior prevalência em crianças e jovens. Entretanto, na Itália, alcança maior prevalência entre 30 e 50 anos (PURCELL E GERIN 1996; FONSECA 1997), apenas 2,5\% dos casos detectados pelo Sistema Nacional de Vigilância tinham menos de 15 anos (STROFFOLINI e col. 1994).

A infecção pelo VHD é menos freqüente que o VHB entre profissionais do sexo e homens que fazem sexo com homens, sugerindo que não é tipicamente uma doença sexualmente transmissível (PURCELL E GERIN 1996). Um estudo de casocontrole com homens que fazem sexo com homem e doadores de sangue, realizado em São Paulo, encontrou 23\% de positividade para o HBsAg no primeiro grupo e apenas $1 \%$ entre os doadores, não foi detectado nenhum caso com anticorpos contra o vírus da hepatite D (FERRAZ e col. 1985)

\section{Ocorrência}

A hepatite D apresenta distribuição mundial, particularmente nas áreas a alta prevalência de hepatite B com grande variação de endemicidade entre as várias regiões. A endemicidade é avaliada pela prevalência de anti-VHD (BENENSON 1995). Utilizando a prevalência de VHD em portadores assintomáticos e em casos de hepatite crônica B, a distribuição mundial ficou dividida em áreas de muito baixa, baixa, média e alta endemicidade (Quadro 4) (PERRENOUD 1995; PURCELL E GERIN 1996; FONSECA 1997), 
Quadro 4 - Distribuição mundial da prevalência de hepatite D

\begin{tabular}{|c|cccc|}
\hline Hepatite B & \multicolumn{4}{|c|}{ Endemicidade ao VHD } \\
& muito baixa & baixa & moderada & alta \\
\hline portador assintomático & & $<5 \%$ & $5-15 \%$ & $>20 \%$ \\
caso crônico & $<10 \%$ & $10-25 \%$ & $30-50 \%$ & $>60 \%$ \\
\hline
\end{tabular}

O estado de portador crônico do VHB (HBsAg positivo) constitui-se provavelmente no principal fator epidemiológico para a disseminação do VHD em áreas de alta endemicidade de infecção pelo VHB, com na Amazônia brasileira, ou em grupos de alto risco como os portadores crônicos do VHB, a exemplo dos usuários de drogas, hemodialisados e politransfundidos.

No Brasil o maior número de casos tem sido notificados na região Amazônica, principalmente na parte ocidental. Nesta região, encontra-se mais de $20 \%$ de positividade ao anti-VHD entre pessoas assintomáticas e de $90 \%$ ou mais entre os casos de hepatite crônica. Em São Paulo e Rio de Janeiro têm tido casos importados de outras regiões, sendo ausentes ou baixa entre os casos residentes (FONSECA 1997).

\subsubsection{HEPATITE E}

O período de incubação do vírus da hepatite $\mathrm{E}$ é de 15 a 54 dias, com média de 6 semanas, variando em diferentes epidemias (BENENSON 1995). O período de transmissibilidade ainda é desconhecido. Estudos com voluntários infectados pelo VHE, por via oral, detectaram o vírus nas fezes, por imunomicroscopia eletrônica, até 34 dias após a exposição. A viremia foi detectada, por PCR, de 22 a 30 dias após a exposição (PURCELL 1996).

A resistência do vírus da hepatite $\mathrm{E}$ a agentes químicos e físicos não foi tão estudada quanto a dos vírus A e B. Não há indícios que o VHE seja mais resistente a esses agentes do que os outros vírus (PERRENOUD 1995). 


\section{Transmissão}

$\mathrm{O}$ vírus da hepatite $\mathrm{E}$ tem muitos aspectos em comum com o da hepatite $\mathrm{A}$. Eles são transmitidos pela mesma via, e na maioria dos casos causam hepatite aguda e de evolução benigna. Entretanto, por ser de transmissão oral-fecal, a hepatite E tem uma taxa de ataque mais elevada entre os adultos jovens (SKIDMORE 1999; TANNO e FAY 1999). Grande parte dos casos ocorre em crianças de áreas endêmicas e confere imunidade permanente. Tem sido sugerido, que a imunidade contra o VHE adquirido na infância não é duradoura, podendo ocorrer a re-infecção em fase mais tardia da vida, quando a doença tende a ser mais severa (SKIDMORE 1999).

A transmissão do vírus do VHE é mais freqüentemente associada ao consumo de água contaminada com fezes (PURCELL 1996; KRAWCZYNSKI e MAST 1999; TANNO e FAY 1999).

A transmissão por alimentos contaminados tem sido referida como causa de algumas epidemias, porém, com exceção daquelas ocorridas na China, essas epidemias não foram confirmadas sorologicamente (KRAWCZYNSKI e MAST 1998). Casos esporádicos de hepatite $\mathrm{E}$ têm sido relacionados ao consumo de molusco “in natura” (CARRILHO e SILVA 1995; PURCELL 1996).

A transmissão pessoa-a-pessoa do VHE parece ser rara, mesmo em locais com condições precárias de saneamento, como os campos de refugiados (PURCELL 1996; KRAWCZYNSKI e MAST 1998). Durante as epidemias, casos secundários no mesmo domicílio são raros (BENENSON 1995).

Estudos realizados durante uma epidemia na Índia comprovaram a transmissão vertical do VHE. Muitas crianças, nascidas de mães infectadas, apresentaram uma hepatite transitória e se curaram, mas uma morreu com necrose hepática. Em experimentos com primatas, a transmissão vertical não foi comprovada (KRAWCZYNSKI e MAST 1998).

A transmissão parenteral é possível, desde que ocorra dentro do período de viremia. Administração de produtos hemoderivados, por exemplo concentrado de fator de coagulação, também têm sido sugeridos como um possível modo de transmissão do VHE, porque os métodos correntes de inativação viral utilizados para esses produtos podem não inativar vírus não envelopados (PURCELL 1996). 


\section{Ocorrência}

Epidemias de hepatite E têm sido relatadas em áreas endêmicas da Ásia, África, Oriente Médio, e América Central, predominantemente em países em desenvolvimento onde as condições de saneamento são inadequadas. Foi registrada uma epidemia de grandes proporções no nordeste da China, envolvendo mais de 100.000 casos, entre 1986 e 1988 (TANNO e FAY 1999; KRAWCZYNSKI e MAST 1998).

A hepatite $\mathrm{E}$ pode ser endêmica em vários países onde epidemias não são observadas, mas apresentam alta incidência de casos esporádicos como Egito, Hong Kong, Senegal, Taiwan e Turquia (KRAWCZYNSKI e MAST 1998).

Em muitos países, onde epidemias não têm sido documentadas (regiões nãoendêmicas), o VHE é responsável por menos de $1 \%$ dos casos de hepatite viral aguda. A maioria desses casos tem sido associada à histórias de viagens para regiões endêmicas. Emigrantes dessas regiões podem portar o VHE e contaminar pessoas em outros países, como foi descrito no caso de imigrantes paquistaneses nos Estados Unidos (CARRILHO e SILVA 1995; KRAWCZYNSKI e MAST 1998).

No Brasil, os primeiros casos de hepatite $\mathrm{E}$ foram descritos na Bahia, em 1993, em 3 casos esporádicos de hepatite não-A, não-B, não-C (PARANA 1997). No mesmo ano, em um levantamento sorológico realizado na região amazônica, detectou-se anticorpos anti-VHE em 6 dos 97 trabalhadores de minas (PANG 1995). Estudo com amostra 1.059 indivíduos da população residente no município de São Paulo encontrou uma prevalência de anticorpos anti-VHE de 1,68\% (FOCACCIA 1998). 


\section{OBJETIVOS}

\section{GERAL}

- Analisar uma proposta de sistema de vigilância das hepatites causadas pelos vírus $\mathrm{A}, \mathrm{B}, \mathrm{C}$ e $\mathrm{E}$ implementado em um município de pequeno porte na área metropolitana da Grande São Paulo, discutindo aspectos de sua operacionalização e sua capacidade de descrever o comportamento das hepatites nessa comunidade com o objetivo de fundamentar e aprimorar estratégias de controle.

\section{ESPECÍFICOS}

- Descrever a freqüência e distribuição das hepatites A, B, C e E no Município segundo seus caracteres epidemiológicos relativos ao tempo, espaço e pessoa.

- Identificar e investigar eventuais surtos epidêmicos das hepatites A e E, analisando seus caracteres epidemiológicos relativos ao tempo, espaço e pessoa.

- Estimar a prevalência de marcadores para as hepatites A, B, C e E em população de gestantes no Município.

- Discutir a experiência implementada em Vargem Grande Paulista como subsídio para o aprimoramento da vigilância das hepatites virais no Estado de São Paulo. 


\section{1. ÁREA DE ESTUDO}

Vargem Grande Paulista é um pequeno município de $29 \mathrm{~km}^{2}$, localizado na região sudoeste da Grande São Paulo, a 45 km do centro da cidade de São Paulo. Foi criado em 1983, quando o Distrito de Raposo Tavares foi desmembrado de Cotia. Na época de sua emancipação, contava com uma população urbana de 11.100 habitantes. Em 1996, com a anexação dos bairros limítrofes do município de Itapevi, a população aumentou em 6.000 habitantes e a área em $8 \mathrm{~km}^{2}$. Segundo a contagem do Instituto Brasileiro de Geografia e Estatística (IBGE) de 1996, tinha uma população de 26.689 habitantes. É um dos Municípios do Estado de São Paulo com maior taxa de crescimento anual (SEADE 2000).

Ainda, segundo estimativa do IBGE, em 1998, a taxa de natalidade geral foi de 24,05/1.000 habitantes, a de natimortalidade 9,51/1.000 nascidos vivos ou mortos e a de mortalidade infantil 21,95/1.000 nascidos vivos (SEADE 2000).

No período de 1994 a agosto de 1995, a Faculdade de Saúde Pública realizou em Vargem Grande Paulista um censo, com o objetivo de identificar o perfil demográfico, caracterizar a população do ponto de vista sócio-econômico e descrever suas condições de vida e saúde. Os dados apurados mostraram que praticamente a metade da população era composta por indivíduos jovens, e que o número de idosos era reduzido (5,5\%). Cerca de 70\% dos habitantes recebiam até 3 salários mínimos. A escolaridade era baixa: $12,2 \%$ da população adulta era analfabeta e $59 \%$ não concluiu o primeiro grau. Os dados referentes ao saneamento mostraram que 65\% dos domicílios eram atendidos pelo sistema de abastecimento de água da Companhia de Saneamento Básico do Estado de São Paulo (SABESP) e que 31\% captavam água por meio de poço ou fonte. Apenas $36 \%$ dos domicílios contavam com sistema de esgoto sanitário e $49 \%$ das famílias despejavam seus dejetos em fossas e valetas, representando um grave problema para o Município. Um aspecto positivo apontado pelo censo é que $70 \%$ da população residia em casas próprias, fato que sugere certa estabilidade quanto à fixação da residência (WESTPHAL 1998). 
O Serviço de Saúde apresentava pequena complexidade, constituído por uma unidade central de atendimento primário, com pronto socorro e ambulatório de especialidades e 4 unidades periféricas de atendimento básico.

\subsection{DESCRIÇÃO DO SISTEMA DE VIGILÂNCIA}

O sistema de vigilância das hepatites A , B, C e E foi implantado por esse projeto em Vargem Grande Paulista em abril de 1997, e por ele mantido até setembro de 1999. Optou-se por um sistema passivo de coleta de dados obtidos pela notificação espontânea dos casos suspeitos de hepatite viral. Entretanto, podemos considerá-lo parcialmente ativo, pois a equipe de vigilância do município realizava sistematicamente a revisão das solicitações das provas de função hepática realizadas pelo corpo médico. Tal procedimento aliado ao critério utilizado para confirmação de caso, que foi a identificação de marcadores sorológicos das hepatites virais sob vigilância, caracteriza-o como um sistema, fundamentalmente, de base laboratorial.

Preocupados com a reprodução da experiência e em sua possível continuidade após o término desse estudo, não foram utilizados recursos adicionais aos existentes no Serviço de Saúde do Município, além do apoio laboratorial para realização do diagnóstico etiológico das hepatites virais.

As etapas seguidas na elaboração do sistema de vigilância das hepatites virais de Vargem Grande Paulista tomaram como referência aquelas genericamente descritas pelo Centers for Disease Control and Prevention (CDC) para qualquer sistema de vigilância (CDC, 1988b).

\subsubsection{Objetivos do sistema}

Com vistas a fornecer subsídios para elaboração de estratégias de prevenção e controle foram definidos os seguintes objetivos para o sistema:

- conhecer a freqüência e distribuição das hepatites A, B, C e E no Município;

- conhecer a prevalência de marcadores das hepatites A, B, C e E na população de gestantes inscritas no Serviço de Pré-natal das Unidades de Saúde do Município; 
- identificar e investigar eventuais surtos e epidemias das hepatites A e E, caracterizando-as no tempo, espaço e pessoa.

\subsubsection{Definições de caso}

O sistema de vigilância utilizou duas definições de caso: uma para caso suspeito e outra para caso confirmado, considerando os aspectos clínicos, epidemiológicos e laboratoriais das hepatites virais.

Caso suspeito: o indivíduo residente no município de Vargem Grande Paulista, e para quem foi solicitada a dosagem dos níveis de bilirrubinas e transaminases, pelos critérios clínicos, laboratoriais e epidemiológicos descritos abaixo:

- apresentava icterícia acompanhada (ou não) dos sinais e sintomas: febre, mal-estar, náusea/vômito, mialgia, colúria, acolia fecal;

- apresentava um ou mais dos seguintes sinais e sintomas: febre, mal-estar, náusea/vômito, mialgia, porém sem icterícia;

- era comunicante ou parceiro sexual de caso confirmado de hepatite viral;

- apresentou sorologia positiva para as hepatites B ou C em triagem de banco de sangue;

- relatou diagnóstico anterior de hepatite;

- fazia uso de drogas injetáveis;

- apresentava sorologia positiva para HIV.

Caso confirmado: paciente que apresentou sorologia positiva para um dos marcadores das hepatites A, B, C e E, descritos no item 3.2.6.

\subsubsection{Fluxograma do sistema}

A figura 11 mostra a representação gráfica dos principais passos seguidos pelas instituições envolvidas no sistema de vigilância das hepatites virais implantado em Vargem Grande Paulista, com as atribuições de cada uma delas. 


\subsubsection{Componentes do sistema}

A população alvo do sistema foram todos os indivíduos residentes em Vargem Grande Paulista. A notificação dos casos suspeitos de hepatite viral foi realizada de forma contínua pelos médicos e profissionais de saúde à equipe de vigilância do município, assim como a revisão de pedidos laboratoriais para testes de função hepática. Para cada caso, foi preenchida uma ficha de investigação laboratorial (anexo 1) com os dados de identificação do paciente e a data do início dos sintomas.

A coleta do sangue foi realizada em um laboratório do Município, que realizou as dosagens das transaminases e bilirrubinas no soro, e foi responsável pelo envio das amostras para o Laboratório de Hepatites do Instituto Adolfo Lutz, onde foram realizados os testes de imunodiagnóstico e moleculares para a identificação dos marcadores das hepatites A, B, C e E.

Os dados foram armazenados e analisados no programa EPI INFO versão 6.0 (CDC, 1994). Para garantir a exatidão dos registros, a entrada dos dados foi realizada em duplicata por operadores diferentes.

O coeficiente de incidência anual das hepatites A, B, C e E foi calculado utilizando-se como numerador o total de casos novos detectados pelo sistema de vigilância e, denominador as estimativas de população para $1^{0}$ de julho de cada ano, divulgadas pelo IBGE.

$\mathrm{Na}$ análise descritiva dos dados foi aplicado o teste do qui-quadrado $\left(\chi^{2}\right)$ para estudar associações entre as freqüências das hepatites e as variáveis de interesse. Foram considerados estatisticamente significantes os valores de $\mathrm{p}<0,05$. 


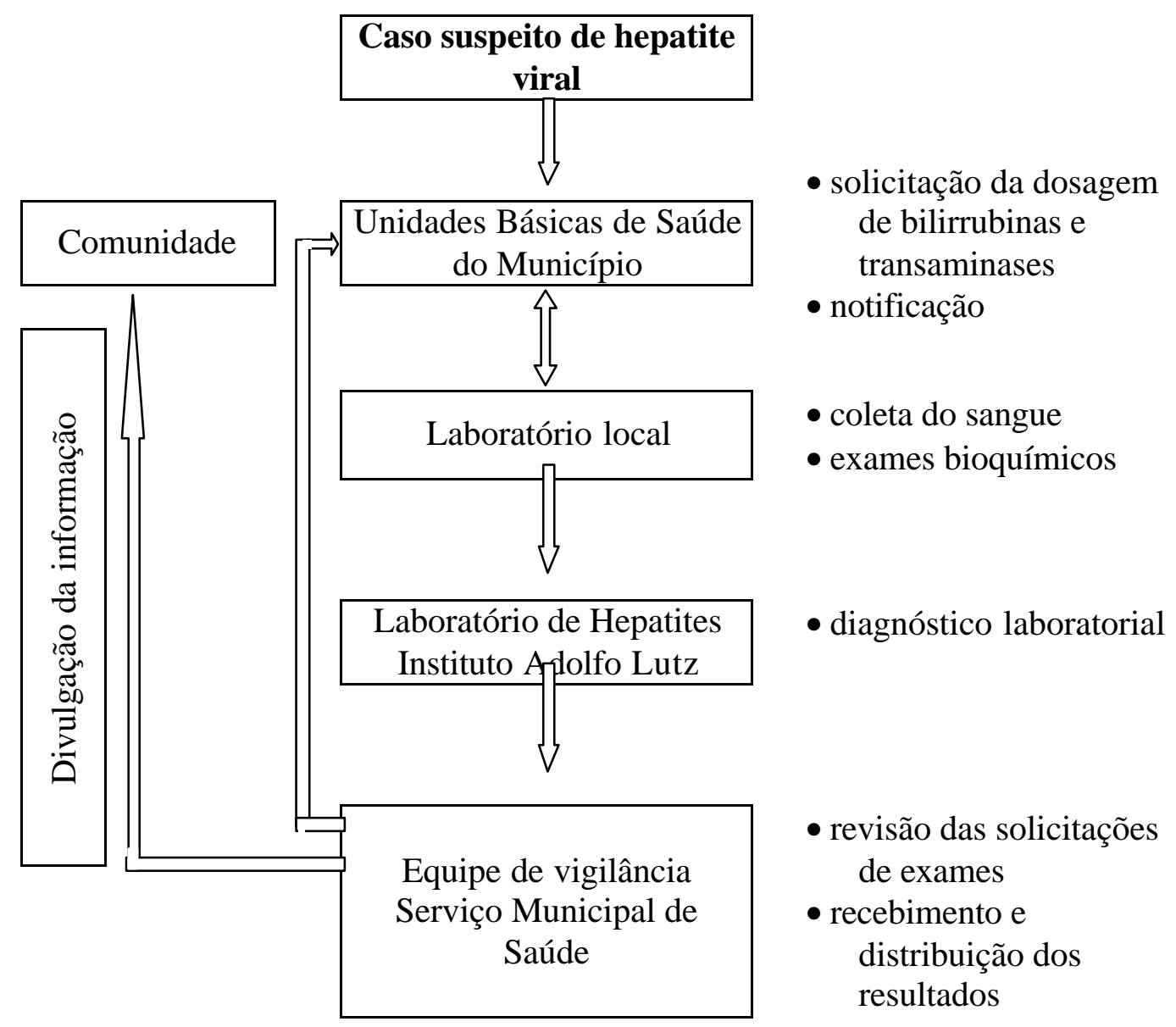

Figura 11 - Fluxograma do sistema de vigilância implantado em Vargem Grande Paulista entre abril de 1997 e setembro de 1999.

\subsubsection{Procedimentos para aumentar a sensibilidade do sistema}

Para melhorar o desempenho do sistema em identificar casos de hepatite viral foram adotadas as seguintes condutas:

1. Incentivo a todos os médicos das Unidades Básicas de Saúde do Município a solicitarem sistematicamente:

- exames para dosagem de bilirrubinas e transaminases nos casos suspeitos de hepatite;

- exames para o diagnóstico das hepatites virais dos pacientes portadores de doenças sexualmente transmissíveis e dependentes de drogas injetáveis. 
2. Introdução na rotina de exames das gestantes do Serviço de Pré-natal a pesquisa de marcadores sorológicos da hepatite B e C.

3. Revisão diária dos pedidos de exames laboratoriais pela equipe de vigilância municipal, para garantir que os pacientes para os quais foi solicitada a dosagem dos níveis de transaminases e bilirrubinas tenham sido notificados como casos suspeitos de hepatite viral.

\subsubsection{Procedimentos de Laboratório}

As amostras de sangue foram obtidas por punção venosa em tubos estéreis e sem anticoagulante. Após centrifugação, o soro foi separado em três alíquotas. Uma delas foi utilizada imediatamente pelo laboratório local para dosagem das bilirrubinas e transaminases. As outras duas alíquotas foram armazenadas a $-20^{\circ} \mathrm{C}$ até serem enviadas para o Laboratório de Hepatites do Instituto Adolfo Lutz. Uma dessas alíquotas foi utilizada para as reações de ensaio imunoenzimático e a outra para as reações de PCR ou para testes confirmatórios.

\section{Determinação dos níveis de bilirrubinas e transaminases}

A dosagem das bilirrubinas no soro foi realizada pelo método colorimétrico direto. $\mathrm{O}$ valor de referência para a bilirrubina total foi de 0,3 a $1,1 \mathrm{mg} / \mathrm{dl}$, para bilirrubina direta de 0,1 a $0,4 \mathrm{mg} / \mathrm{dl}$ e para bilirrubina indireta de 0,2 a $0,7 \mathrm{mg} / \mathrm{dl}$, segundo o teste comercial utilizado.

A quantificação das transaminases foi realizada pelo método colorimétrico de ponto final, empregando testes comerciais. No decorrer do estudo houve a troca do teste utilizado, alterando o valor de referência para o limite superior normal dos níveis de transaminases. Para ALT, esse valor passou de $36 \mathrm{UI} / \mathrm{mL}$ para $20 \mathrm{UI} / \mathrm{mL}$ e para AST, de $32 \mathrm{UI} / \mathrm{mL}$ para $18 \mathrm{UI} / \mathrm{mL}$. Para facilitar a análise e interpretação dos resultados, o valor da determinação dessas enzimas foi dividido pelo valor do limite superior normal (x L.S.N.) especificado pelo teste.

\section{Pesquisa dos marcadores das hepatites virais}

A técnica de ensaio imunoenzimático (ELISA), utilizando "kits" comerciais, 
foi utilizada na pesquisa dos marcadores das hepatites $\mathrm{A}, \mathrm{B}, \mathrm{C}$ e $\mathrm{E}$, seguindo o fluxograma de laboratório apresentado na figura 12.

As amostras que apresentaram sorologia positiva ou indeterminada para o anti-VHC pelo ELISA foram testadas novamente pela técnica do "immunoblot" de terceira geração.

A pesquisa do RNA do vírus da hepatite $C$, por PCR, foi realizada em todos os casos suspeitos de hepatite viral. O RNA foi extraído do soro pelo método do isotiocianato de guanidina, transformado em cDNA com a transcriptase reversa do vírus da leucemia murina e amplificado por "nested" PCR com os "primers" descritos por GARSON e colaboradores (1990a, 1990b). O material amplificado foi visualizado em gel de agarose corado com brometo de etídio. 


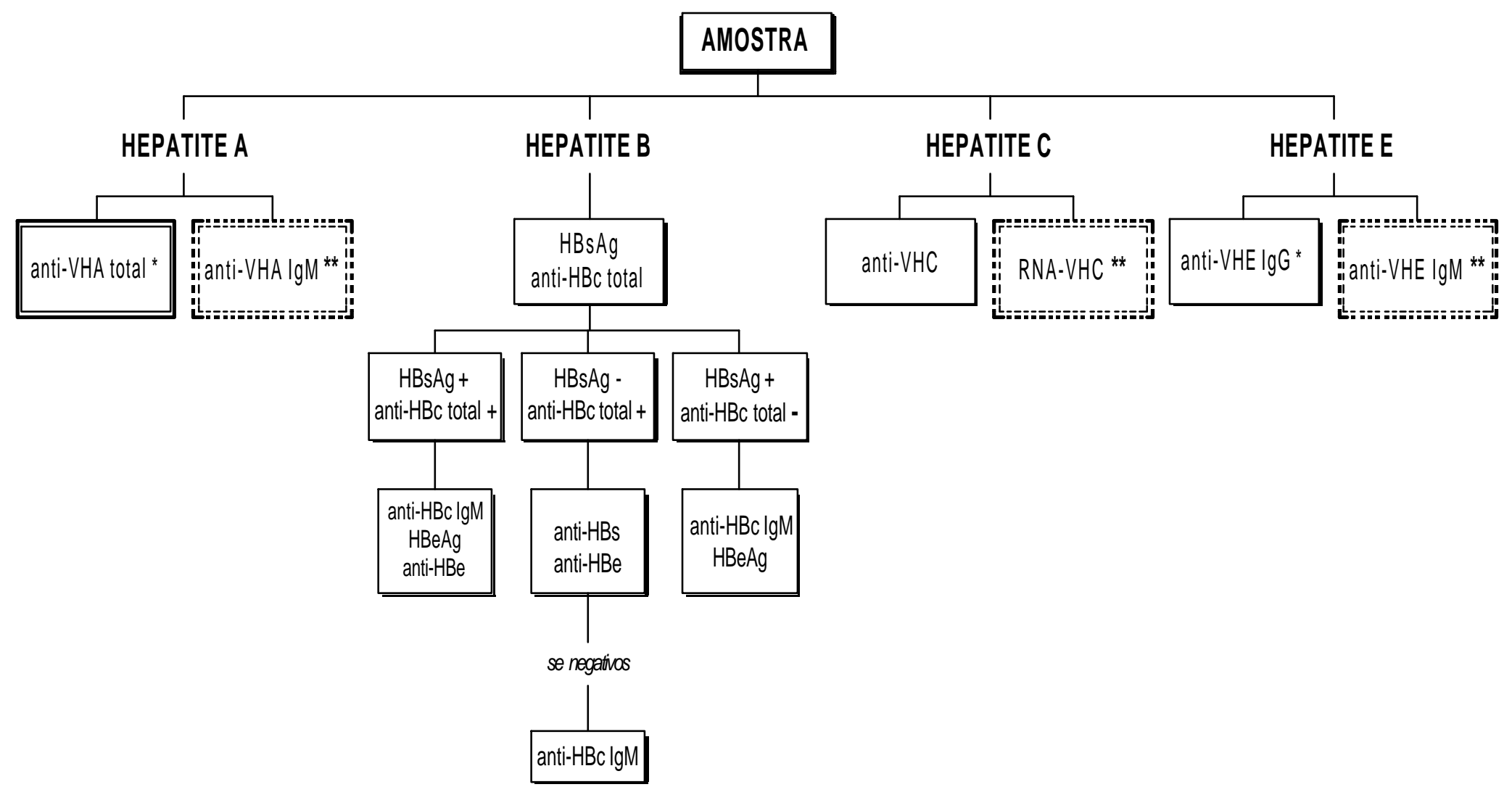

Figura 12 - Fluxograma do diagnóstico laboratorial para as gestantes e para confirmação dos casos suspeitos de hepatite viral * Marcadores pesquisados apenas nas amostras de gestantes

** Marcadores pesquisados apenas nas amostras de casos suspeitos 



\subsection{INVESTIGAÇÃO DE SURTOS}

O procedimento para a investigação dos surtos obedeceu as seguintes etapas:

\section{$1^{\text {a }}$ etapa - definição de caso}

Considerou-se caso suspeito o indivíduo residente em Vargem Grande Paulista, que manifestasse icterícia de início súbito, acompanhada de sintomas ou não, nos últimos 2 meses, ou que fosse comunicante de caso confirmado de hepatite A. Classificou-se, como caso confirmado, o indivíduo com sorologia positiva para hepatite aguda A (presença de anti-VHA IgM) que residisse na área atingida ou freqüentasse a instituição afetada.

\section{$2^{\mathrm{a}}$ etapa - confirmação da existência do surto}

Nesta etapa, elaboravam-se listas dos casos suspeitos acrescidos das principais informações relativas a aspectos clínicos e epidemiológicos.

Em seguida, com fundamento nas definições de caso, buscava-se verificar se a distribuição dos casos confirmados realmente configurava um surto, ou se tratavase de casos esporádicos não relacionados. Vale esclarecer que para fins operacionais, o conceito adotado para surtos epidêmicos foi o seguinte:

"uma forma particular de epidemia, na qual temos a ocorrência de dois ou mais casos relacionados entre si no tempo e/ou espaço, atingindo um grupo específico de pessoas, configurando-se um claro excesso de casos se comparado com a freqüência normal do agravo em questão no grupo populacional atingido." (WALDMAN, 1998)

O número de casos confirmados de hepatite $\mathrm{A}$ encontrado durante o surto foi comparado, sempre que possível, ao número de casos notificados no mesmo período em anos anteriores na mesma região.

\section{$3^{\text {a }}$ etapa - atividades de campo}

Foram adotadas as seguintes estratégias durante a investigação de campo: 
- visitas domiciliares aos casos confirmados para preenchimento de um formulário detalhado, a "Ficha de Investigação de Caso Confirmado de Hepatite Viral" (anexo 3);

- os contatos domiciliares foram convidados a colher sangue para a realização de exames bioquímicos e de imunodiagnóstico;

- visitas aos ambientes freqüentados pelos casos confirmados ou comunicantes (creches, escolas, ambiente de trabalho), na busca de novos casos.

\section{$4^{\mathrm{a}}$ etapa - análise dos dados}

Os dados coletados foram analisados elaborando-se gráficos, tabelas, mapas da área de estudo, buscando identificar e organizar as informações de acordo com as variáveis relativas ao lugar, tempo e pessoa, para:

- conhecer a distribuição espacial dos casos e as taxas de ataque por local de ocorrência

- construir a curva epidêmica

- calcular as taxas de ataque específicas por sexo, faixa etária, grupo sócio econômico 


\subsection{PREVALÊNCIA DE MARCADORES DAS HEPATITES A, B, C E E EM GESTANTES}

Além dos casos notificados, incluiu-se, no Sistema de Vigilância das Hepatites Virais implantado em Vargem Grande Paulista, o acompanhamento de uma população sentinela formada pelas gestantes inscritas no Serviço de Pré-natal do Município, aceitando-a como grupo que de certa forma representa a população adulta jovem. A avaliação da prevalência dos marcadores sorológicos das hepatites virais nesse grupo contribui para a melhor descrição do comportamento das hepatites na comunidade.

Para cada gestante foi preenchida uma ficha de investigação laboratorial (anexo 2) contendo informações de identificação e um pequeno questionário quanto aos fatores de risco e história anterior de hepatite. Os marcadores sorológicos das hepatites virais que foram pesquisados nessa população estão representados no fluxograma da figura 12 .

\subsection{ASPECTOS ÉTICOS}

Os pacientes com suspeita de hepatite viral e as gestantes que procuraram o Serviço de pré-natal foram convidados a participar do estudo. Aqueles que aceitaram, assinaram um termo de consentimento (anexos 4 e 5), após serem esclarecidos quanto aos objetivos do projeto.

O Comitê de Ética em Pesquisa do Instituto Adolfo Lutz - CEPIAL enquadrou este projeto na categoria "aprovado", no que concerne à Resolução $\mathrm{N}^{\circ}$ 196/96 sobre Pesquisa Envolvendo Seres Humanos / Conselho Nacional de Saúde / Ministério da Saúde / Brasília / 1996. 


\subsection{CARACTERIZAÇÃO DAS HEPATITES VIRAIS COM FUNDAMENTO EM DADOS DE NOTIFICAÇÃO}

\subsubsection{CARACTERIZAÇÃO DOS CASOS SUSPEITOS}

O sistema de vigilância das hepatites virais desenvolvido em Vargem Grande Paulista, entre abril de 1997 e setembro de 1999, identificou 125 casos suspeitos de hepatite viral, entre sintomáticos e assintomáticos. No primeiro grupo incluem-se os 57 casos que foram notificados por critérios clínicos, ou seja, indivíduos que procuraram o serviço de saúde com quadro clínico sugestivo de hepatite viral. Os sessenta e oito casos assintomáticos foram notificados por critérios epidemiológicos e laboratoriais: 44 por serem comunicantes de casos confirmados de hepatite viral; 22 por referirem história anterior de hepatite, como sorologia positiva na triagem de banco de sangue ou algum diagnóstico clínico ou laboratorial anterior e 02 por serem usuários de drogas ou apresentarem sorologia positiva para HIV, aqui designados de grupo de risco para as hepatites virais (Figura 13). 


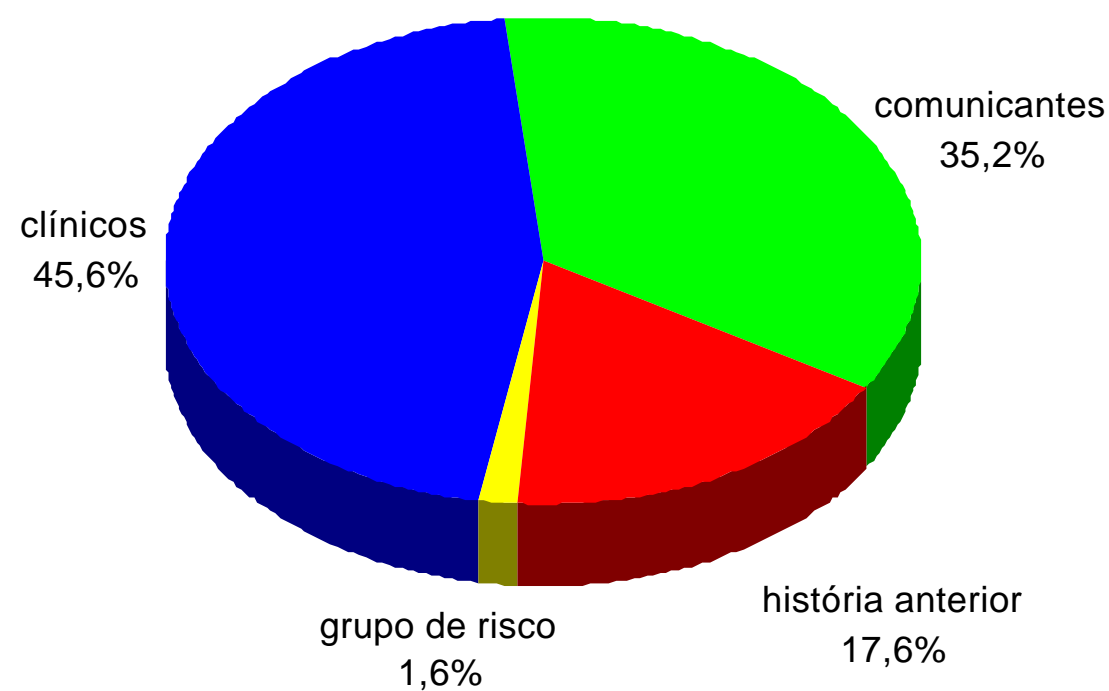

Figura 13 - Critérios utilizados para notificação de casos $(\mathrm{n}=125)$

A idade dos indivíduos que participaram do estudo variou de 1 a 78 anos, com média de 25,1 anos e mediana de 24 anos. A distribuição por faixa etária e sexo está apresentada na Tabela 1.

Tabela 1 - Casos suspeitos de hepatite viral segundo faixa etária e sexo, abril de 1997 e setembro de 1999, Vargem Grande Paulista.

\begin{tabular}{cccc}
\hline $\begin{array}{c}\text { Faixa etária } \\
\text { (em anos) }\end{array}$ & $\begin{array}{c}\text { Masculino } \\
\mathrm{n}\end{array}$ & $\begin{array}{c}\text { Feminino } \\
\mathrm{n}\end{array}$ & $\begin{array}{c}\text { Total } \\
\mathrm{n}(\%)\end{array}$ \\
\hline $\mathbf{0}$ a 4 & 05 & 06 & $11(8,8)$ \\
$\mathbf{5}$ a 9 & 07 & 13 & $20(16,0)$ \\
$\mathbf{1 0}$ a 19 & 11 & 11 & $22(17,6)$ \\
$\mathbf{2 0}$ a 29 & 12 & 08 & $20(16,0)$ \\
$\mathbf{3 0}$ a 39 & 11 & 15 & $26(20,8)$ \\
$\mathbf{4 0}$ a 49 & 09 & 05 & $14(11,2)$ \\
$\mathbf{5 0}$ a 59 & 05 & 03 & $08(6,4)$ \\
$\mathbf{6 0}$ a 69 & 01 & 01 & $02(1,6)$ \\
$\mathbf{7 0}$ e mais & 01 & 01 & $02(1,6)$ \\
\hline Total & $62(49,6 \%)$ & $63(50,3 \%)$ & $125(100,0)$ \\
\hline
\end{tabular}




\subsubsection{CARACTERIZAÇÃO DOS CASOS CONFIRMADOS}

Entre os 125 casos suspeitos notificados ao sistema, 41 casos $(32,8 \%)$ foram confirmados como hepatite A, B, C ou E. Dentre esses, 70,7\% (29/41) apresentaram sinais ou sintomas compatíveis com quadro de hepatite.

A Tabela 2 relaciona a média e mediana da idade dos casos confirmados de hepatite viral. A média das idades dos casos confirmados de hepatite A foi menor que a das outras hepatites e, as diferenças foram estaticamente significantes.

Tabela 2 - Média e mediana das idades dos casos de hepatites A, B, C e E.

\begin{tabular}{cccc}
\hline Hepatite & $\mathbf{n}^{\mathbf{0}}$ de casos & $\begin{array}{c}\text { Idade média } \\
(\mathrm{em} \text { anos })\end{array}$ & $\begin{array}{c}\text { Mediana } \\
(\mathrm{em} \text { anos })\end{array}$ \\
\hline $\mathbf{A}$ & 30 & 10,3 & 8,5 \\
$\mathbf{B}$ & 04 & 28,3 & 27,5 \\
$\mathbf{C}$ & 04 & 40,3 & 41,0 \\
$\mathbf{E}$ & 03 & 33,0 & 41,0 \\
\hline \multicolumn{4}{l}{ (Kruskal-wallis $H=20,69 ; p<0,05)$}
\end{tabular}

Não houve diferenças estatisticamente significantes na distribuição dos casos de hepatite A, B, C e E por sexo ( $p>0,05)$.

A determinação dos níveis de alanina aminotransferase (ALT) e de aspartato aminotransferase (AST) foi realizada em 80,5\% (33/41) dos casos confirmados de hepatite A, B, C ou E. Os resultados são apresentados na Tabela 3.

Tabela 3 - Níveis de ALT e AST, em número de vezes o limite superior normal (x L.S.N.), nos casos confirmados

\begin{tabular}{ccccccc}
\hline & & & & $\begin{array}{c}<\mathbf{1 , 0} \\
(x L . S . N .)\end{array}$ & $\begin{array}{c}1,0 \text { a 2,5 } \\
(x L . S . N .)\end{array}$ & $\begin{array}{c}>\mathbf{2 , 5} \\
(x L . S . N .)\end{array}$ \\
\cline { 5 - 7 } & \multirow{2}{*}{ média } & $\min$ & $\max$ & & $\mathrm{n}(\%)$ & $\mathrm{n}(\%)$ \\
\hline ALT & 10,1 & 0,2 & 38,1 & $08(24,2)$ & $03(9,1)$ & $22(66,7)$ \\
AST & 11,4 & 0,6 & 81,0 & $04(12,1)$ & $06(18,2)$ & $23(69,7)$ \\
\hline
\end{tabular}


As médias das transaminases dos casos das hepatites $\mathrm{A}, \mathrm{B}, \mathrm{C}$ e E são apresentadas na Tabela 4. Observa-se que os valores médios mais altos são os dos casos de hepatite A e B. Entretanto as diferenças entre os diferentes tipos de hepatites não foram estatisticamente significantes

Tabela 4 - Valores médios das transaminases dos casos de hepatite A, B, C e E

\begin{tabular}{cccc}
\hline Hepatite & $\mathbf{n}^{\mathbf{0}}$ de casos & ALT* (x L.S.N.) & $\begin{array}{c}\text { AST** }(\mathrm{x} \\
\text { L.S.N.) }\end{array}$ \\
\hline A & 30 & 11,8 & 13,0 \\
B & 4 & 12,0 & 15,8 \\
C & 4 & 1,1 & 1,5 \\
E & 3 & 2,8 & 0,8 \\
\hline
\end{tabular}

* Kruskal-wallis $H=6,72 ; p>0,05$

** Kruskal-wallis $H=6,35 ; p>0,05$

Foi realizada a dosagem das bilirrubinas em 73,2\% (30/41) dos casos confirmados. A Tabela 5 mostra o resultado da dosagem de bilirrubinas entre os casos confirmados de hepatite A, B, C ou E.

Tabela 5 - Níveis das bilirrubinas: total, direta e indireta, em $\mathrm{mg} / \mathrm{dL}$, nos casos confirmados de hepatite A, B, C ou E.

\begin{tabular}{cccccc}
\hline Bilirrubina & média & Min & max & $\begin{array}{c}\text { normal } \\
\mathrm{n}(\%)\end{array}$ & $\begin{array}{c}\text { elevada } \\
\mathrm{n}(\%)\end{array}$ \\
\hline Total & 5,0 & 0,5 & 14,8 & $07(23,3)$ & $23(76,7)$ \\
Indireta & 1,4 & 0,2 & 4,3 & $08(26,7)$ & $22(73,3)$ \\
Direta & $3,6)$ & 0,1 & 11,4 & $09(30,0)$ & $21(70,0)$ \\
\hline
\end{tabular}

Observando a Tabela 6, que traz as médias das bilirrubinas dos casos por hepatite, verifica-se que os valores médios mais altos são os dos casos de hepatite B. A diferença entre as médias das bilirrubinas nas diferentes hepatites foi estatisticamente significantes. 
Tabela 6 - Valores médios das bilirrubinas dos casos de hepatite A, B, C e E

\begin{tabular}{|c|c|c|c|c|}
\hline \multirow{2}{*}{ Hepatites } & \multirow{2}{*}{$n^{0}$ de casos } & \multicolumn{3}{|c|}{ Bilirrubina (mg/dL) } \\
\hline & & total* & Indireta*** & Direta $* * *$ \\
\hline $\mathbf{A}$ & 30 & 4,6 & 1,3 & 3,4 \\
\hline $\mathbf{B}$ & 4 & 11,4 & 2,7 & 8,8 \\
\hline $\mathbf{C}$ & 4 & 1,2 & 0,7 & 0,6 \\
\hline $\mathbf{E}$ & 3 & 0,8 & 0,5 & 0,3 \\
\hline
\end{tabular}

Observou-se que 19,0\% (16/84) dos casos não confirmados apresentaram níveis elevados das transaminases e/ou bilirrubinas. Dentre esses, aproximadamente 1,2\% (1/84) apresentou elevação apenas das transaminases, 3,6\% (3/84) das bilirrubinas e 14,3\% (12/84) tanto das bilirrubinas como das transaminases.

\subsubsection{CARACTERÍSTICAS DOS CASOS DE HEPATITE A}

Foram detectados 30 casos de hepatite A aguda no decorrer do estudo. A média de idade foi 10,3 anos, sendo que 63,3\% (19/30) tinham menos de 10 anos. As diferenças observadas na distribuição desses casos por faixa etária foram estatisticamente significantes (Tabela 7).

Tabela 7 - Distribuição dos casos de hepatite A, por faixa etária.

\begin{tabular}{cccc}
\hline Faixa etária & \multicolumn{3}{c}{ Freqüiência } \\
(em anos) & $\mathrm{N}$ & $\%$ & $\%$ acumulada \\
\hline $\mathbf{0}$ a 4 & 04 & 13,3 & 13,3 \\
$\mathbf{5}$ a 9 & 15 & 50,0 & 63,3 \\
$\mathbf{1 0}$ a 19 & 07 & 23,4 & 86,7 \\
$\mathbf{2 0}$ a 29 & 03 & 10,0 & 96,7 \\
$\mathbf{3 0}$ a 39 & 01 & 3,3 & 100,0 \\
\hline$\left.\chi^{2}=31,97 ; p<0,05\right)$ & Usar o qui quadrado
\end{tabular}


Não foram observadas diferenças significativas na distribuição dos casos de hepatite A por sexo ( $\mathrm{p}>0,05)$.

Vinte e um casos $(70,0 \%)$ de hepatite A foram sintomáticos. Foi possível determinar os níveis das transaminases e bilirrubinas em $22(73,3 \%)$ casos de hepatite A aguda, dos quais 81,8\% (18/22) apresentaram transaminases elevados. A média da ALT foi 11,8 x L.S.N. e da AST 13,0 x L.S.N. (Tabela 8). As dosagens das bilirrubinas total, direta e indireta estão apresentadas na Tabela 9.

Tabela 8 - Níveis das transaminases dos casos de hepatite A aguda, em número de vezes o limite superior normal (x L.S.N.).

\begin{tabular}{ccccccc}
\hline & média & Min & max & $\begin{array}{c}<\mathbf{1 , 0}(\mathrm{x} \\
\text { L.S.N.) } \\
\mathrm{n}(\%)\end{array}$ & $\begin{array}{c}\mathbf{1 , 0} \text { a 2,5 }(\mathrm{x} \\
\text { L.S.N. } \\
\mathrm{n}(\%)\end{array}$ & $\begin{array}{c}>\mathbf{2 , 5}(\mathrm{x} \\
\text { L.S.N. } \\
\mathrm{n}(\%)\end{array}$ \\
\hline ALT & 11,8 & 0,4 & 38,1 & $04(18,2)$ & $01(4,5)$ & $17(77,3)$ \\
AST & 13,0 & 1,1 & 81,0 & $02(9,1)$ & $03(13,6)$ & $17(77,3)$ \\
\hline
\end{tabular}

Tabela 9 - Níveis de bilirrubina total, direta e indireta dos casos de hepatite A aguda em $\mathrm{mg} / \mathrm{dL}$

\begin{tabular}{cccccc}
\hline Bilirrubina & média & Min & max & $\begin{array}{c}\text { normal } \\
\mathrm{n}(\%)\end{array}$ & $\begin{array}{c}\text { elevada } \\
\mathrm{n}(\%)\end{array}$ \\
\hline Total & 5,0 & 0,5 & 14,8 & $04(18,2)$ & $18(81,8)$ \\
Indireta & 1,4 & 0,3 & 3,4 & $04(18,2)$ & $18(81,8)$ \\
Direta & 3,6 & 0,1 & 11,4 & $05(22,7)$ & $17(77,3)$ \\
\hline
\end{tabular}

Dos 30 casos de hepatite A detectados pelo sistema de vigilância, 18 estavam associados a ocorrência de um surto num dos bairros do município.

A suspeita da ocorrência de evento foi levantada após a análise da distribuição no tempo e espaço, dos casos notificados pelas Unidades de Saúde. Esses casos concentraram-se entre fevereiro e maio de 1998, como pode ser observado na Figura 15, que mostra a distribuição dos casos por data de início dos sintomas. Apenas um dos casos não soube informar a data de início dos sintomas, e 
não está representado no gráfico. Dos 12 casos que foram notificados nos 4 primeiros meses de 1998, 10 casos residiam em Tijuco Preto. A distribuição dos casos por local de residência é apresentada na figura 14. Essas observações sugeriram a existência de um surto de hepatite A no bairro de Tijuco Preto. Esse surto foi investigado com a identificação de oito casos adicionais, sendo que os resultados dessa investigação serão apresentados a seguir.

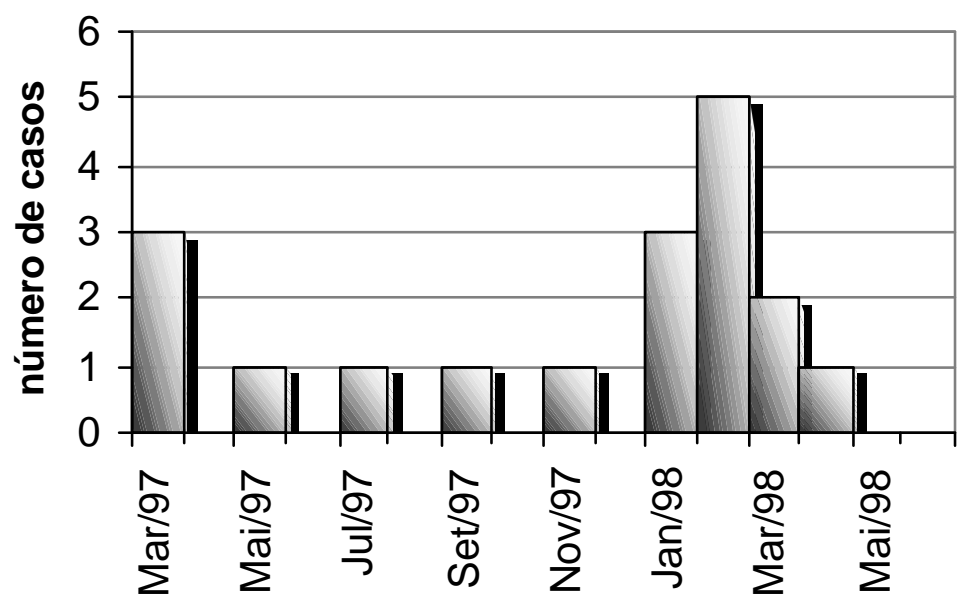

Figura 15 - Distribuição dos casos de hepatite A aguda identificados em período anterior a investigação do surto, por data do início dos sintomas

Figura 14 - Distribuição dos casos de hepatite A aguda, por bairro.

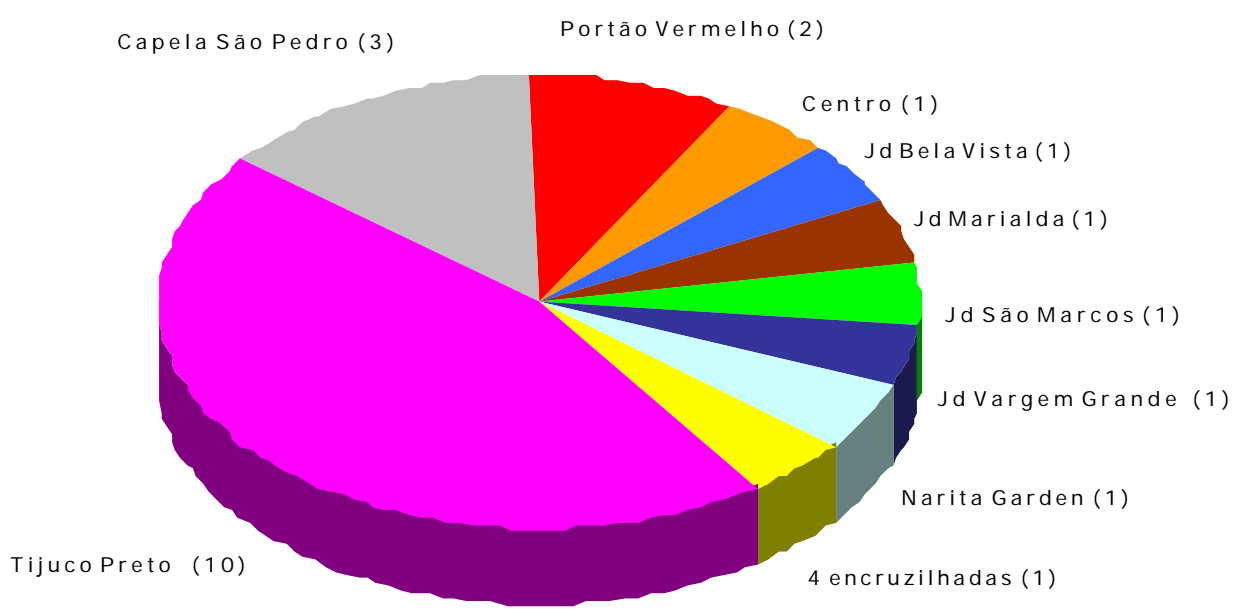




\subsubsection{INVESTIGAÇÃO DO SURTO DE HEPATITE A}

A investigação de campo do surto de hepatite A ocorrido no Bairro de Tijuco Preto começou em 28 de abril de 1998, com a visita aos domicílios dos casos conhecidos de hepatite A, aos locais de ensino e ao posto de saúde na busca de casos adicionais.

Os casos conhecidos foram entrevistados em suas residências, ocasião em que lhes foi perguntado se tinham conhecimento de outros possíveis casos entre seus amigos e familiares. Seus contatos domiciliares foram convidados a colher sangue para pesquisa do anti-VHA IgM. Foram visitados os domicílios dos 10 casos identificados pelo sistema, não foi possível entrevistar apenas um dos casos. Esse domicílio foi visitado por 3 vezes sem sucesso.

No total, foram feitas 49 solicitações de coleta de sangue, entre os contatos domiciliares dos casos conhecidos e os possíveis casos mencionados pelos entrevistados, ou pelos profissionais das escolas e do posto do bairro. Foram atendidas 27 solicitações $(55,1 \%)$.

Com a investigação, foram identificados 8 casos adicionais de hepatite A aguda (anti-VHA IgM positivo), todos assintomáticos. Assim, o surto de hepatite A no Bairro de Tijuco Preto abrangeu 18 casos conhecidos.

\section{Características do surto epidêmico relativas ao tempo}

A Figura 16 mostra a data do início dos sintomas dos casos de hepatite A identificados em Tijuco Preto no primeiro semestre de 1998 (curva epidêmica). A maioria dos casos ocorreu durante um período de 48 dias, de 27 de janeiro a 15 de março. O primeiro caso, cuja data de início dos sintomas foi 01/11/97, provavelmente não está relacionado ao surto e por isso não foi utilizado no cálculo das taxas de ataque.

Não é possível determinar a duração exata do surto, devido ao grande número de casos assintomáticos, porém a curva epidêmica oferece uma visão aproximada de suas dimensões e das características do evento. 


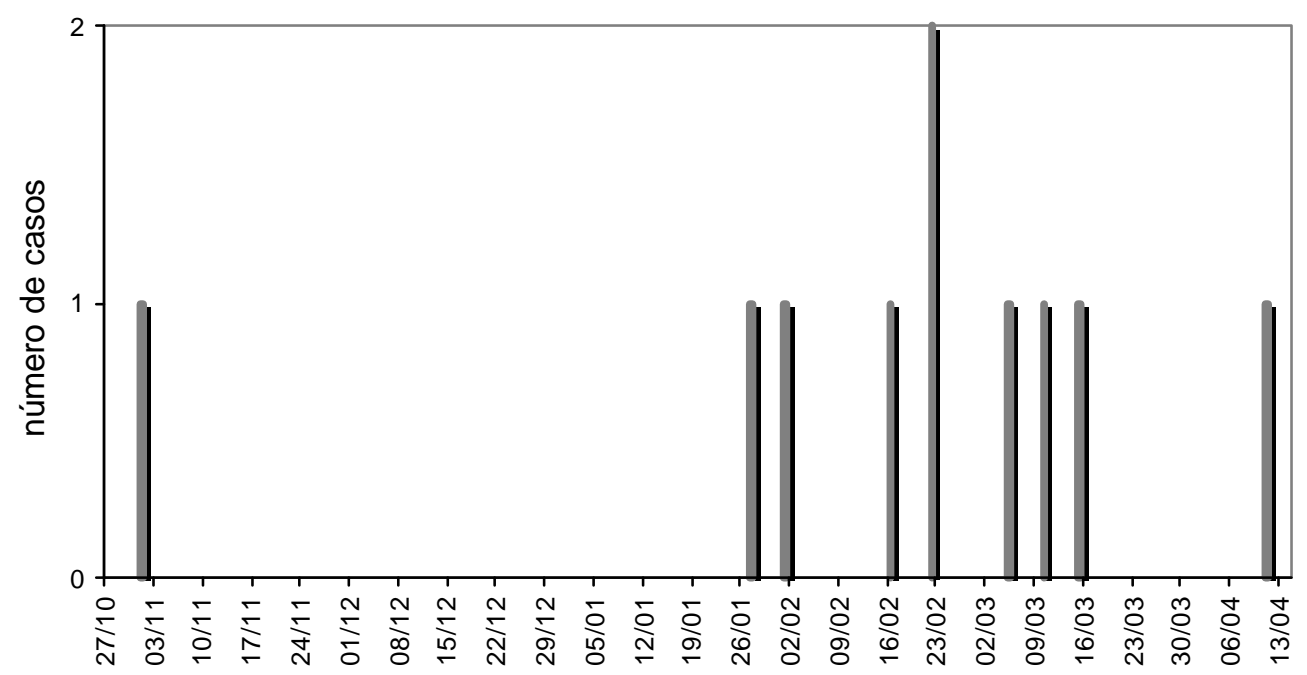

Figura 16 - Data do início dos sintomas dos casos confirmados do surto de hepatite A no bairro de Tijuco Preto em 1998.

\section{Características do surto epidêmico segundo os atributos das pessoas}

A idade dos casos envolvidos no surto variou de 1 a 23 anos, com média de 7,8 anos e mediana de 6 anos. A distribuição por faixa etária e sexo dos casos de hepatite A é apresentada na Tabela 10.

Tabela 10 - Casos de hepatite A associados ao surto ocorrido no Bairro de Tijuco Preto, no primeiro semestre de 1998, segundo o sexo e faixa etária. Taxa de ataque

\begin{tabular}{cccc}
\hline $\begin{array}{c}\text { Faixa etária } \\
\text { (em anos) }\end{array}$ & $\begin{array}{c}\text { Masculino } \\
\mathrm{N}\end{array}$ & $\begin{array}{c}\text { Feminino } \\
\mathrm{N}\end{array}$ & $\begin{array}{c}\text { Total } \\
\mathrm{n}(\%)\end{array}$ \\
\hline $\mathbf{0}$ a 4 & 01 & 01 & $02(11,8)$ \\
$\mathbf{5}$ a 9 & 03 & 09 & $12(70,6)$ \\
$\mathbf{1 0}$ a 19 & 01 & 01 & $02(11,8)$ \\
$\mathbf{2 0}$ a 29 & 0 & 01 & $01(5,8)$ \\
\hline Total & $05(29,4 \%)$ & $12(70,6 \%)$ & 17 \\
\hline
\end{tabular}


As taxas de ataque foram calculadas utilizando-se como denominador a população estimada pelo censo de 1996 (IBGE). Para as mulheres foi de 0,89/1000 habitantes e para os homens de 0,38/1000 habitantes. As taxas de ataque por faixa etária são apresentadas na Tabela 11.

Tabela 11 - Taxa de ataque por hepatite A por 1.000 habitantes, por faixa etária, Bairro de Tijuco Preto, primeiro semestre de 1998.

\begin{tabular}{cc}
\hline $\begin{array}{c}\text { Faixa etária } \\
(\text { em anos })\end{array}$ & $\begin{array}{c}\text { Taxa de ataque } \\
(\text { por } 1.000)\end{array}$ \\
\hline 0 a 4 & 0,88 \\
$\mathbf{5}$ a 9 & 4,02 \\
10 a 19 & 0,33 \\
20 a 29 & 0,29 \\
\hline Total & 0,64 \\
\hline
\end{tabular}

\section{Características do surto epidêmico relativas ao lugar}

A Tabela 12 traz a relação dos casos de hepatite A do surto de Tijuco Preto por endereço, bairro e data de coleta de sangue.

Tabela 12 - Casos de hepatite A associados ao surto no Bairro de Tijuco Preto, por idade, sexo, endereço, e data de coleta de sangue, 1998.

\begin{tabular}{|c|c|c|c|c|c|}
\hline $\begin{array}{c}\text { CAS } \\
\mathbf{O}\end{array}$ & $\begin{array}{r}\text { IDA } \\
\text { DE }\end{array}$ & $\begin{array}{c}\text { SEX } \\
\text { O }\end{array}$ & ENDEREÇO & BAIRRO & $\begin{array}{r}\text { COLE } \\
\text { TA* }\end{array}$ \\
\hline \multirow{2}{*}{$01 * *$} & \multirow{2}{*}{30} & \multirow{2}{*}{ M } & \multirow{2}{*}{ R: Min. Ouro Branco, 396} & Tijuco & $12 / 02 / 9$ \\
\hline & & & & Preto & 8 \\
\hline \multirow{2}{*}{$\mathbf{0 2}$} & \multirow{2}{*}{06} & \multirow{2}{*}{ M } & \multirow{2}{*}{ R: Inúbia Paulista, 126} & Tijuco & $16 / 02 / 9$ \\
\hline & & & & Preto & 8 \\
\hline \multirow{2}{*}{$\mathbf{0 3}$} & \multirow{2}{*}{05} & \multirow{2}{*}{$\mathrm{F}$} & \multirow{2}{*}{$\begin{array}{l}\text { R: Min. Ouro Branco, } \\
2548\end{array}$} & Tijuco & 08/05/9 \\
\hline & & & & Preto & 8 \\
\hline \multirow{2}{*}{04} & \multirow{2}{*}{06} & \multirow{2}{*}{$\mathrm{F}$} & \multirow{2}{*}{ R: Riachuelo, 43} & Tijuco & 03/03/9 \\
\hline & & & & Preto & 8 \\
\hline \multirow{2}{*}{05} & \multirow{2}{*}{07} & \multirow{2}{*}{$\mathrm{F}$} & \multirow{2}{*}{ R: Nova Aliança, 161} & Tijuco & 03/03/9 \\
\hline & & & & Preto & 8 \\
\hline \multirow{2}{*}{06} & \multirow{2}{*}{11} & \multirow{2}{*}{$\mathrm{F}$} & \multirow{2}{*}{$\begin{array}{l}\text { R: São Paulo das Missões, } \\
61\end{array}$} & Tijuco & $12 / 02 / 9$ \\
\hline & & & & Preto & 8 \\
\hline \multirow{2}{*}{07} & \multirow{2}{*}{06} & \multirow{2}{*}{$\mathrm{F}$} & R: Min. Ouro Branco, & Tijuco & 03/02/9 \\
\hline & & & 2112 & Preto & 8 \\
\hline
\end{tabular}




\begin{tabular}{|c|c|c|c|c|c|}
\hline 08 & 08 & $\mathrm{~F}$ & R: Inúbia Paulista, 31 & $\begin{array}{l}\text { Tijuco } \\
\text { Preto }\end{array}$ & $\begin{array}{c}19 / 03 / 9 \\
8\end{array}$ \\
\hline 09 & 10 & M & R: Riachuelo, 43 & $\begin{array}{l}\text { Tijuco } \\
\text { Preto }\end{array}$ & $\begin{array}{c}19 / 03 / 9 \\
8\end{array}$ \\
\hline 10 & 09 & M & R: Riachuelo, 183 & $\begin{array}{l}\text { Tijuco } \\
\text { Preto }\end{array}$ & $\begin{array}{c}08 / 05 / 9 \\
8\end{array}$ \\
\hline 11 & 03 & M & R: Riachuelo, 183 & $\begin{array}{l}\text { Tijuco } \\
\text { Preto }\end{array}$ & $\begin{array}{c}08 / 05 / 9 \\
8\end{array}$ \\
\hline 12 & 06 & $\mathrm{~F}$ & R: Caissara, 10 & $\begin{array}{c}\mathrm{Pq} \\
\text { Agreste }\end{array}$ & $\begin{array}{c}17 / 06 / 9 \\
8\end{array}$ \\
\hline 13 & 01 & $\mathrm{~F}$ & R: Caissara, 10 & $\begin{array}{c}\text { Pq } \\
\text { Agreste }\end{array}$ & $\begin{array}{c}17 / 06 / 9 \\
8\end{array}$ \\
\hline 14 & 23 & $\mathrm{~F}$ & R: Caissara, 10 & $\begin{array}{c}\mathrm{Pq} \\
\text { Agreste }\end{array}$ & $\begin{array}{c}13 / 08 / 9 \\
8\end{array}$ \\
\hline 15 & 09 & M & $\begin{array}{l}\text { R: São Paulo das Missões, } \\
61\end{array}$ & $\begin{array}{l}\text { Tijuco } \\
\text { Preto }\end{array}$ & $\begin{array}{c}13 / 08 / 9 \\
8\end{array}$ \\
\hline 16 & 09 & $\mathrm{~F}$ & $\begin{array}{l}\text { R: São Paulo das Missões, } \\
61\end{array}$ & $\begin{array}{l}\text { Tijuco } \\
\text { Preto }\end{array}$ & $\begin{array}{c}13 / 08 / 9 \\
8\end{array}$ \\
\hline 17 & 09 & $\mathrm{~F}$ & $\begin{array}{l}\text { R: São Paulo das Missões, } \\
61\end{array}$ & $\begin{array}{c}\text { Tijuco } \\
\text { Preto }\end{array}$ & $\begin{array}{c}13 / 08 / 9 \\
8\end{array}$ \\
\hline 18 & 06 & $\mathrm{~F}$ & $\begin{array}{l}\text { R: São Paulo das Missões, } \\
61\end{array}$ & $\begin{array}{l}\text { Tijuco } \\
\text { Preto }\end{array}$ & $\begin{array}{c}13 / 08 / 9 \\
8\end{array}$ \\
\hline
\end{tabular}

* data da coleta de sangue, não coincide com a data de início dos sintomas

** provavelmente não está associado ao surto

A análise da distribuição dos casos por faixa etária mostra que cerca de $82,3 \%$ dos casos tinham entre 5 e 10 anos, fato que levou a uma análise mais detalhada das escolas freqüentadas por essas crianças (Tabela 13).

Tabela 13 - Casos de hepatite A associados ao surto no Bairro de Tijuco Preto, por idade, sexo, endereço, e data de coleta de sangue.

\begin{tabular}{|c|c|c|c|}
\hline CASO & ESCOLA & SÉRIE* & PERÍODO \\
\hline 02 & EMEIF Flor de Lis & Jardim & matutino \\
\hline 03 & $\begin{array}{l}\text { EE Paulo Soares da } \\
\text { Silva }\end{array}$ & Jardim & vespertino \\
\hline 04 & $\begin{array}{l}\text { EE Paulo Soares da } \\
\text { Silva }\end{array}$ & $1^{\mathrm{a}} \mathrm{B}$ & matutino \\
\hline 05 & EMEIF Flor de Lis & Jardim & matutino \\
\hline 06 & $\begin{array}{l}\text { EE Paulo Soares da } \\
\text { Silva }\end{array}$ & $4^{\mathrm{a}} \mathrm{B}$ & matutino \\
\hline 07 & EMEIF Flor de Lis & Jardim & vespertino \\
\hline 08 & $\begin{array}{l}\text { EE Paulo Soares da } \\
\text { Silva }\end{array}$ & $2^{a} B$ & matutino \\
\hline
\end{tabular}




\begin{tabular}{|c|c|c|c|}
\hline 09 & $\begin{array}{l}\text { EE Paulo Soares da } \\
\text { Silva }\end{array}$ & $4^{\mathrm{a}} \mathrm{B}$ & matutino \\
\hline 10 & $\begin{array}{l}\text { E Fazenda Santa } \\
\text { Paula }\end{array}$ & $3^{\mathrm{a}}$ & matutino \\
\hline 12 & Escola do Agreste & jardim & matutino \\
\hline 15 & $\begin{array}{l}\text { EE Paulo Soares da } \\
\text { Silva }\end{array}$ & $3^{\mathrm{a}}$ & matutino \\
\hline 16 & EMEIF Flor de Lis & $3^{\mathrm{a}}$ & matutino \\
\hline 17 & $\begin{array}{l}\text { EE Paulo Soares da } \\
\text { Silva }\end{array}$ & $3^{\mathrm{a}}$ & matutino \\
\hline 18 & $\begin{array}{l}\text { EE Paulo Soares da } \\
\text { Silva }\end{array}$ & jardim & matutino \\
\hline
\end{tabular}

Os casos 02 e 05 estudavam na mesma sala da EMEIF Flor de Lis, o primeiro adoeceu em 27 de janeiro e o segundo em 22 de fevereiro. Os casos 06 e 09 também estudavam na mesma sala, e a data do inicio dos sintomas foi 22 de janeiro e 15 de março, respectivamente.

Os casos 12 a 18 são irmãos ou primos do caso 06. Os casos 12, 13 e 14, apesar de residirem em outro bairro, foram associados ao surto de Tijuco Preto, porque passavam o dia na casa do caso 06 enquanto a mãe trabalhava.

O caso 09 é irmão do caso 04 que adoeceu em 16 de fevereiro, eram vizinhos dos casos 10 e 11, e passavam grande parte do tempo brincando juntos.

Essas observações aliadas às características da curva epidêmica sugerem que a forma predominante de transmissão do vírus da hepatite A durante o surto foi pessoa a pessoa (via fecal-oral).

A figura 17 mostra a localização das residências dos casos de hepatite A, das escolas e da Unidade de Saúde no bairro de Tijuco Preto 


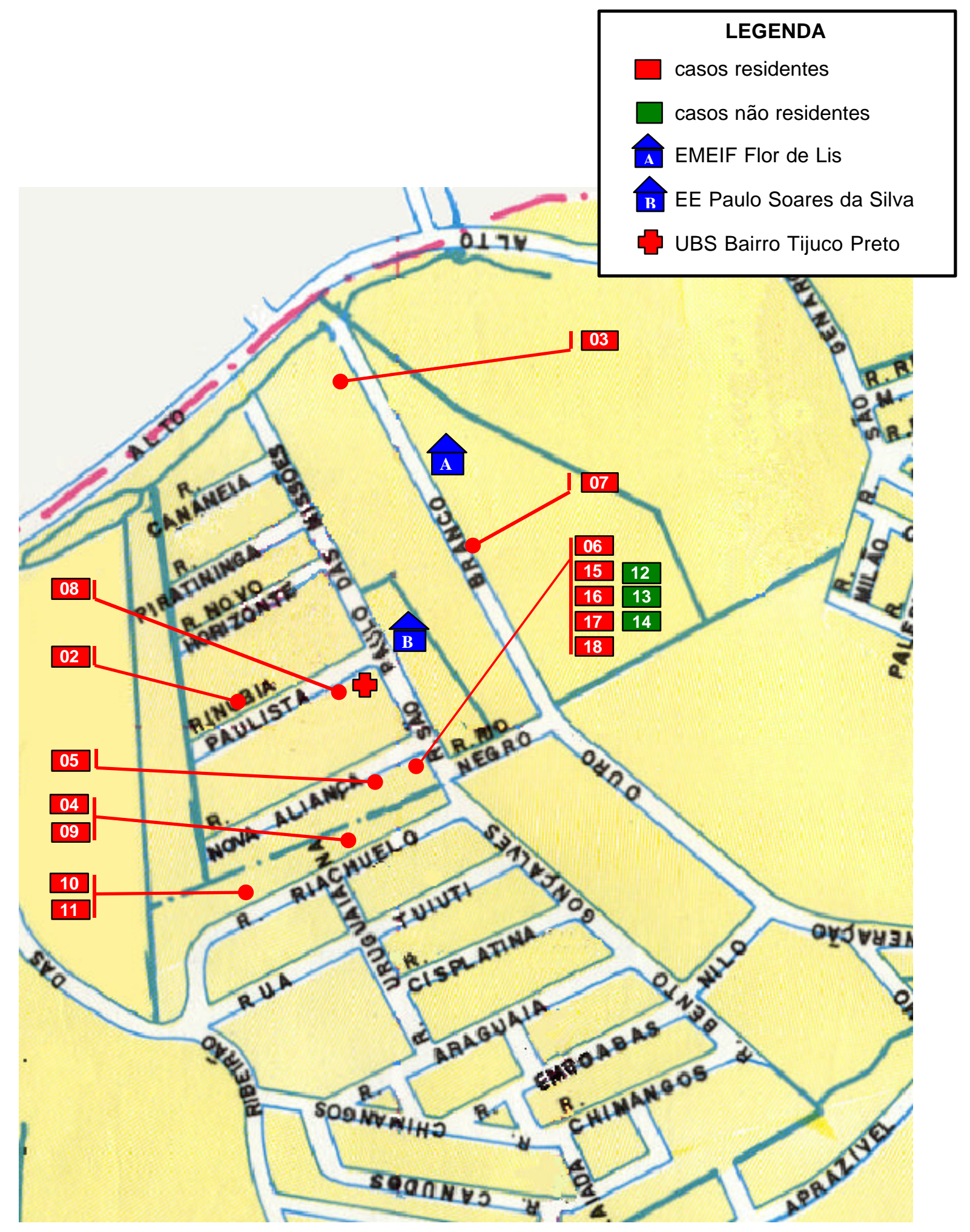

Figura 17 - Distribuição dos casos envolvidos no surto de hepatite A no bairro de Tijuco Preto 


\subsubsection{CARACTERÍSTICAS DOS CASOS DE HEPATITE B}

Foram detectados 4 casos de hepatite B aguda. Todos apresentaram sinais e sintomas de hepatite aguda, e sorologia positiva para o anti-HBc IgM e HBsAg. A média de idade desses pacientes foi 28,3 anos. A média das transaminases foi $12,0 \mathrm{x}$ L.S.N. para ALT, 15,8 x L.S.N. para AST, e das bilirrubinas foi 11,4 mg/dL para total, $8,8 \mathrm{mg} / \mathrm{dL}$ para direta e $2,7 \mathrm{mg} / \mathrm{dL}$ para indireta. Foi solicitada uma $2^{\mathrm{a}}$ amostra desses pacientes para seguimento sorológico. Apenas 2 casos atenderam e foram positivos para o anti-HBc IgM, porém negativas para o HBsAg. A idade, o sexo, os valores de transaminases e bilirrubinas, assim como o intervalo de tempo entre as 2 amostras dos casos de hepatite B aguda são apresentados na Tabela 14.

Tabela 14 - Casos de hepatite B, fase aguda, segundo idade, sexo, níveis de transaminases e bilirrubinas (1a e 2 a amostras) e intervalo entre as 2 amostras.

\begin{tabular}{|c|c|c|c|c|c|c|c|c|c|}
\hline \multirow{2}{*}{$\begin{array}{l}\mathbf{N}^{\mathbf{0}} \text { do } \\
\text { Caso }\end{array}$} & \multirow{2}{*}{$\begin{array}{c}\text { Idade } \\
\text { (anos } \\
\text { ) } \\
\end{array}$} & \multirow[b]{2}{*}{ Sexo } & \multirow{2}{*}{$\begin{array}{c}\text { Amostr } \\
\mathbf{a}\end{array}$} & \multirow{2}{*}{$\begin{array}{c}\text { ALT } \\
(\mathrm{x} \\
\text { L.S.N. }) \\
\end{array}$} & \multirow{2}{*}{$\begin{array}{c}\text { AST } \\
(\mathrm{x} \\
\text { L.S.N. }) \\
\end{array}$} & \multicolumn{3}{|c|}{ Bilirrubinas (mg/dL) } & \multirow{2}{*}{$\begin{array}{l}1 \mathbf{a}- \\
2 \mathbf{a}^{*}\end{array}$} \\
\hline & & & & & & $\begin{array}{c}\text { Tota } \\
\mathbf{l} \\
\end{array}$ & Direta & $\begin{array}{c}\text { Indiret } \\
\mathbf{a}\end{array}$ & \\
\hline 91 & 17 & M & $1^{\mathrm{a}}$ & 6,3 & 11,7 & 12,0 & 7,7 & 4,3 & \\
\hline \multirow[t]{2}{*}{325} & 26 & $\mathrm{~F}$ & $1^{\mathrm{a}}$ & 11,9 & 10,5 & 9,2 & 7,6 & 1,6 & 4 meses \\
\hline & & & $2^{\mathrm{a}}$ & 0,6 & 0,6 & 0,9 & 0,7 & 0,2 & \\
\hline \multirow[t]{2}{*}{595} & 41 & $\mathrm{~F}$ & $1^{\mathrm{a}}$ & 11,1 & 12,5 & 12,7 & 10,3 & 2,4 & 8 meses \\
\hline & & & $2^{\mathrm{a}}$ & NR & NR & NR & NR & NR & \\
\hline 596 & 29 & $\mathrm{~F}$ & $1^{\mathrm{a}}$ & 18,9 & 28,5 & 11,8 & 9,5 & 2,3 & \\
\hline
\end{tabular}

* intervalo entre a $1^{a}$ e $2^{a}$ amostra

(NR) não realizado

Foram observados 4 casos com perfil sugestivo de hepatite B crônica: positivos para HBsAg e anti-HBc total, e negativos para o anti-HBc IgM. Também foi solicitada a $2^{\mathrm{a}}$ amostra desses pacientes. Apenas 2 atenderam e continuavam positivos para o HBsAg. A idade, sexo, os valores de transaminases e bilirrubinas, assim como o intervalo de tempo entre as 2 amostras dos casos portadores de HBsAg são apresentados na Tabela 15. 
O único caso que apresentou níveis elevados de transaminases e bilirrubinas foi o 827 . Esse caso apresentava hepatite E aguda.

Tabela 15 - Portadores de HBsAg segundo idade, sexo, níveis de transaminases e bilirrubinas (1a e $2 \mathrm{a}$ amostras) e intervalo entre as 2 amostras

\begin{tabular}{|c|c|c|c|c|c|c|c|c|c|}
\hline \multirow{2}{*}{$\begin{array}{l}\mathrm{N}^{0} \text { do } \\
\text { Caso }\end{array}$} & \multirow{2}{*}{$\begin{array}{c}\text { Idade } \\
\text { (anos } \\
\text { ) } \\
\end{array}$} & \multirow[b]{2}{*}{ Sexo } & \multirow{2}{*}{$\begin{array}{c}\text { Amostr } \\
\text { a }\end{array}$} & \multirow{2}{*}{$\begin{array}{c}\text { ALT } \\
(x \\
\text { L.S.N. })\end{array}$} & \multirow{2}{*}{$\begin{array}{c}\text { AST } \\
(\mathrm{x} \\
\text { L.S.N. })\end{array}$} & \multicolumn{3}{|c|}{ Bilirrubinas (mg/dL) } & \multirow{2}{*}{$\begin{array}{l}1 \mathrm{a}- \\
2 \mathrm{a}^{*}\end{array}$} \\
\hline & & & & & & $\begin{array}{c}\text { Tota } \\
1\end{array}$ & Direta & $\begin{array}{c}\text { Indiret } \\
\mathbf{a}\end{array}$ & \\
\hline \multirow[t]{2}{*}{253} & 35 & $\mathrm{~F}$ & $1^{\mathrm{a}}$ & 0,8 & 0,9 & 1,1 & 0,2 & 0,9 & 6 meses \\
\hline & & & $2^{\mathrm{a}}$ & 0,6 & 0,6 & 0,9 & 0,7 & 0,2 & \\
\hline \multirow[t]{2}{*}{394} & 19 & $\mathrm{~F}$ & $1^{\mathrm{a}}$ & NR & NR & NR & NR & NR & 2 meses \\
\hline & & & $2^{\mathrm{a}}$ & NR & NR & NR & NR & NR & \\
\hline 575 & 33 & M & $1^{\mathrm{a}}$ & 0,7 & 0,6 & 0,9 & 0,2 & 0,7 & \\
\hline 827 & 41 & M & $1^{\mathrm{a}}$ & 33,3 & 20,0 & NR & NR & NR & \\
\hline
\end{tabular}

* intervalo entre a $1^{a}$ e $2^{a}$ amostra $(N R)$ não realizado

\subsubsection{CARACTERÍSTICAS DOS CASOS DE HEPATITE C}

Dos 125 casos suspeitos de hepatite viral detectados pelo Sistema de Vigilância, 4 (3,2\%) apresentaram anticorpos anti-VHC e o RNA viral. A Tabela 16 traz a idade, sexo e os valores de bilirrubina e transaminases.

Tabela 16 - Casos de hepatite C segundo idade, níveis de transaminases e bilirrubinas.

\begin{tabular}{cccccccc}
\hline \multirow{2}{*}{ Caso } & Idade & Sexo & $\begin{array}{c}\text { ALT } \\
(\mathrm{x}\end{array}$ & $\begin{array}{c}\text { AST } \\
(\mathrm{x}\end{array}$ & \multicolumn{3}{c}{ Bilirrubinas (mg/dL) } \\
& & & L.S.N.) & L.S.N.) & Total & Direta & Indireta \\
\hline $\mathbf{2 2 9}$ & 50 & $\mathrm{~F}$ & 0,3 & 0,6 & 1,3 & 1,1 & 0,2 \\
$\mathbf{3 0 5}$ & 32 & $\mathrm{M}$ & 3,9 & 2,1 & $\mathrm{NR}$ & $\mathrm{NR}$ & $\mathrm{NR}$ \\
$\mathbf{3 1 6}$ & 53 & $\mathrm{~F}$ & 2,6 & 1,3 & 1,5 & 1,1 & 0,4 \\
$\mathbf{4 2 7}$ & 26 & $\mathrm{M}$ & 1,8 & 1,3 & 0,9 & 0,2 & 0,7 \\
\hline
\end{tabular}


Apenas o caso 229 foi sintomático, os outros três procuraram as Unidades de Saúde por orientação de outros médicos, como no caso dos indivíduos que apresentaram sorologia positiva para anti-VHC nos testes de triagem de banco de sangue. Examinando o prontuário desses pacientes, verificou-se que os 4 relataram transfusão de sangue.

Foi sugerido aos portadores do VHC que procurassem o Grupo de Hepatologia do Hospital das Clínicas. Apenas 2 atenderam, foram submetidos à biópsia e entraram nos protocolos de tratamento.

\subsubsection{CARACTERÍSTICAS DOS CASOS DE HEPATITE E}

Foram identificados 3 pacientes com anti-VHE IgM, todos foram detectados pelo sistema por critérios clínicos. A Tabela 17 mostra a idade, sexo, e o resultado da determinação das enzimas dos casos de hepatite E aguda.

Tabela 17 - Casos de hepatite E por idade, níveis de transaminases e bilirrubinas.

\begin{tabular}{ccccccc}
\hline \multirow{2}{*}{ Caso } & Idade & $\begin{array}{c}\text { ALT } \\
(\mathrm{x}\end{array}$ & $\begin{array}{c}\text { AST } \\
(\mathrm{x}\end{array}$ & \multicolumn{2}{c}{ Bilirrubinas $(\mathrm{mg} / \mathrm{dL})$} \\
L.S.N.) & L.S.N.) & Total & Direta & $\begin{array}{c}\text { Indiret } \\
\mathbf{a}\end{array}$ \\
\hline $\mathbf{0 4}$ & 17 & 0,4 & 0,4 & 0,8 & 0,3 & 0,5 \\
$\mathbf{5 7 7}$ & 41 & 0,8 & 1,0 & 0,7 & 0,5 & 0,2 \\
$\mathbf{8 2 7}$ & 41 & 33,3 & 20,0 & $\mathrm{NR}$ & $\mathrm{NR}$ & $\mathrm{NR}$ \\
\hline$(N R)$ & não realizado & & & &
\end{tabular}




\subsubsection{INCIDÊNCIA DAS HEPATITES A, B, E E PREVALÊNCIA DA HEPATITE C}

O coeficiente de incidência das hepatites A, B e E foi calculado utilizando-se como numerador o total de casos novos detectados pelo sistema de vigilância e, como denominador a estimativa da população para o ano de 1998, divulgada pelo IBGE. A Tabela 18 mostra a incidência das hepatites no Município e o marcador sorológico pesquisado para esse cálculo.

Durante o estudo foram identificados 4 casos de hepatite C, 1 em 1997 e 3 em 1998, o que eqüivale a uma prevalência de 3,5/100.000 habitantes e 9,8/100.000 habitantes respectivamente. Dado que não é possível determinar se a infecção é recente ou não apenas pela detecção do anti-VHC e do RNA do vírus, não foi calculada a incidência.

Tabela 18 - Coeficiente de incidência das hepatites A, B e E, por 100.000 habitantes de abril de 1997 a setembro de 1999, Vargem Grande Paulista

\begin{tabular}{cccccccc}
\hline \multirow{2}{*}{ Hepatite } & \multirow{2}{*}{ Marcador } & \multicolumn{2}{c}{$\mathbf{1 9 9 7}^{1}$} & \multicolumn{2}{c}{$\mathbf{1 9 9 8}^{2}$} & \multicolumn{2}{c}{$\mathbf{1 9 9 9}^{3}$} \\
& & $\mathrm{n}$ & $\mathrm{CI}$ & $\mathrm{n}$ & $\mathrm{CI}$ & $\mathrm{n}$ & $\mathrm{CI}$ \\
\hline A & Anti-VHA IgM & 06 & 21,1 & 21 & 69,3 & 03 & 9,3 \\
B & Anti-HBc IgM & 01 & 3,5 & 03 & 9,8 & 0 & 0 \\
E & Anti-VHE IgM & 01 & 3,5 & 01 & 3,3 & 01 & 3,1 \\
\hline
\end{tabular}

(n) - número de casos

(CI) - coeficiente de incidência por 100.000 habitantes

1 - de abril a dezembro de 1997

2 - de janeiro a dezembro de 1998

3 - de janeiro a setembro de 1999

\subsection{PREVALÊNCIA DOS MARCADORES DAS HEPATITES A, B, C E E EM GESTANTES}

Participaram do estudo 793 gestantes matriculadas no Serviço de Pré-natal do Município, entre abril de 1997 e setembro de 1999. Trinta e sete gestantes colheram duas amostras de sangue em gestações diferentes, entretanto só foram analisados os resultados da primeira amostra. A idade variou de 13 a 43 anos, com média de 23,8 anos e mediana de 23 anos. A distribuição por faixa etária é apresentada na Tabela 19. 
Tabela 19 - Distribuição das gestantes por faixa etária.

\begin{tabular}{cc}
\hline $\begin{array}{c}\text { Faixa etária } \\
(\text { em anos })\end{array}$ & $\begin{array}{c}\text { Freqüência } \\
\mathrm{n}(\%)\end{array}$ \\
\hline $\mathbf{1 0}$ a $\mathbf{1 4}$ & $13(1,6)$ \\
$\mathbf{1 5}$ a 19 & $228(28,7)$ \\
$\mathbf{2 0}$ a 24 & $241(30,4)$ \\
$\mathbf{2 5}$ a 29 & $160(20,2)$ \\
$\mathbf{3 0}$ a 34 & $95(12,0)$ \\
$\mathbf{3 5}$ a 39 & $45(5,7)$ \\
$\mathbf{4 0}$ a 44 & $11(1,4)$ \\
\hline Total & 793 \\
\hline
\end{tabular}

Das 793 gestantes, $751(94,7 \%)$ apresentaram anticorpos contra o VHA; a distribuição por faixa etária está representada na Tabela 20. Quanto mais alta a faixa etária, maior a prevalência de anti-VHA; verificou-se que essa tendência foi estatisticamente significante.

Tabela 20 - Prevalência anticorpos totais anti-VHA entre as gestantes, segundo faixa etária.

\begin{tabular}{ccc}
\hline $\begin{array}{c}\text { Faixa etária } \\
(\text { em anos })\end{array}$ & \multicolumn{2}{c}{ Prevalência $(\%)$} \\
\hline $\mathbf{1 0}$ a 19 & 90,5 & $(218 / 241$ \\
$\mathbf{2 0}$ a 29 & 96,3 & $\begin{array}{c}(386 / 401 \\
)\end{array}$ \\
$\mathbf{3 0}$ a 39 & 97,1 & $(136 / 140$ \\
$\mathbf{4 0}$ a 49 & 100,0 & $(11 / 11)$ \\
\hline Total & 94,7 & $(751 / 793$ \\
\hline$\chi^{2}$ de tendência $\left.=10,47 ; p<0,05\right)$
\end{tabular}

Quanto aos marcadores de hepatite B, 39 (4,9\%) gestantes foram positivas para o anti-HBc, sendo que uma $(0,13 \%)$ delas também foi positiva para o HBsAg. A Tabela 21 mostra a distribuição das gestantes com anti-HBc por faixa etária. Quanto mais alta a faixa etária maior a prevalência de anti-HBc, verificou-se que essa 
tendência foi estatisticamente significante.

Tabela 21 - Gestantes com anticorpos totais anti-HBc, segundo faixa etária.

\begin{tabular}{ccc}
\hline $\begin{array}{c}\text { Faixa etária } \\
(\mathrm{em} \text { anos) }\end{array}$ & \multicolumn{2}{c}{ Prevalência $(\%)$} \\
\hline $\mathbf{1 0}$ a 19 & 1,7 & $(04 / 241)$ \\
$\mathbf{2 0}$ a 29 & 5,7 & $(23 / 401)$ \\
$\mathbf{3 0}$ a 39 & 7,9 & $(11 / 140)$ \\
$\mathbf{4 0}$ a 49 & 9,1 & $(01 / 11)$ \\
\hline Total & 4,9 & $(39 / 793)$ \\
\hline$\chi^{2}$ de tendência $=8,5 ;$ & $p<0,05)$
\end{tabular}

Foi realizada a pesquisa dos marcadores complementares da hepatite B (anti$\mathrm{HBc}$ IgM, anti-HBe e HBeAg) da gestante positiva para o HBsAg e todos foram negativos. Colhida 3 meses após a primeira, a $2^{\mathrm{a}}$ amostra foi positiva para o $\mathrm{HBs} A g$ anti-HBc e anti-HBe. As bilirrubinas e transaminases estavam normais.

Cinco gestantes foram positivas na pesquisa de anticorpos contra o vírus da hepatite C pela técnica do ELISA e pelo "imunoblott", com idade entre 18 e 27 anos, média de 22,6 anos e mediana de 23 anos.

Sete gestantes apresentaram anticorpos do tipo IgG contra o vírus da hepatite E, com idade variando de 14 a 36 anos, média de 25,3 anos e mediana de 29 anos.

A Tabela 22 resume a prevalência dos marcadores das hepatites A, B, C e E das gestantes, com os respectivos intervalos de confiança, durante o período de estudo. 
Tabela 22 - Prevalência dos marcadores das hepatites A, B, C, e E em gestantes matriculadas no Serviço Pré-natal, de abril de 1997 a setembro de 1999, Vargem Grande Paulista.

\begin{tabular}{cccc}
\hline Hepatite & Marcador & Prevalência (\%) & $\begin{array}{c}\text { Intervalo de confiança } \\
\mathbf{9 5 \%}\end{array}$ \\
\hline A & Anti-VHA total & 94,7 & $92,8-96,1$ \\
B & Anti-HBc total & 4,9 & $3,6-6.7$ \\
& HBsAg & 0,1 & $0,0-0,8$ \\
C & Anti-VHC & 0,6 & $0,2-1,6$ \\
E & Anti-VHE IgG & 0,8 & $0,4-1,9$ \\
\hline
\end{tabular}

\subsection{IMPACTO DA IMPLANTAÇÃO DO SISTEMA DE VIGILÂNCIA NO MUNICÍPIO}

Com o objetivo de levantar subsídios para discussão dos resultados obtidos pelo sistema de vigilância de hepatites virais implantado no Município, a médica responsável pela equipe de vigilância foi contatada, 18 meses após o término do projeto, para relatar as contribuições que o sistema trouxe ao Serviço de Saúde. Esse relato é transcrito a seguir:

”- reciclando o conhecimento em diagnóstico clínico, epidemiológico e laboratorial das hepatites virais e também no diagnostico de outros tipos de hepatite;

- atentou-nos a padronização do acompanhamento clínico e vigilância dos contatos e controle sanitário dos casos de hepatite;

- dentro dessa padronização tornou-se rotina o diagnóstico etiológico das hepatites $A, B, C$ e $E$;

- uma vez que o Estado normalizou a detecção do vírus da hepatite B no prénatal, foi muito fácil adequá-la ao serviço;

- detectamos gestantes portadoras de HBsAg e pudemos fazer e prevenção vertical;

- conseguimos uma referência terciária para os portadores crônicos de hepatite $B$ e $C$; 
- a vigilância sanitária está usando os dados do projeto para ações com a SABESP e a Secretaria Municipal de Obras.” 


\section{DISCUSSÃ̃}

Em 1963, Alexander LANGMUIR define vigilância como "a contínua e sistemática coleta, análise e interpretação de dados essenciais de saúde para planejar, implementar e avaliar práticas de saúde pública, intimamente integrada com a periodicidade de disseminação desses dados para aqueles que necessitam conhecêlos". Esse autor foi cuidadoso ao distinguir a vigilância tanto da responsabilidade direta das ações de controle, como da pesquisa epidemiológica, entretanto reconhece a importância da interface dessas três atividades (THACKER e BERKELMAN 1988a). A vigilância é um instrumento da saúde pública, que tem por objetivo oferecer as bases técnicas para o planejamento, implementação e avaliação dos programas de saúde (WALDMAN 1998). A vigilância deve desempenhar o papel de olhos e ouvidos das autoridades sanitárias, oferecendo-lhes subsídios para decisões, como bem definiu LANGMUIR, em 1971.

A vigilância tem demonstrado ser um dos mais importantes instrumentos em saúde pública para a identificação de tendências, grupos e fatores de risco das hepatites virais, subsidiando a formulação de estratégias e políticas de prevenção e controle dessas infecções. Os sistemas de vigilância e as ações de controle das hepatites virais seguem diferentes padrões, geralmente adaptados às suas características em cada país, e principalmente à disponibilidade de recursos.

Nos Estados Unidos, por exemplo, desde 1954 existe um sistema nacional de notificação dos casos de hepatites, porém a vigilância teve início em 1960 (LANGMUIR, 1963). Atualmente, existem nesse país dois sistemas passivos de vigilância das hepatites virais. No primeiro, os casos são notificados ao Centers for Diseases Control and Prevention (CDC) em todos os estados e territórios. A confirmação do caso é realizada apenas com fundamento em dados clínicos e epidemiológicos, dispensando a utilização testes sorológicos. A análise das informações referentes aos casos de hepatite $A$, hepatite $B$ e hepatite $C /$ não-A não-B é publicada periodicamente no Morbidity and Mortality Weekly Report - MMWR (CDC 2000). 
O segundo, é o Sistema de Vigilância das Hepatites Virais de responsabilidade do Hepatitis Branch, Division of Viral and Ricketsial Diseases do CDC. Ele provê informações mais completas que o primeiro já que inclui a confirmação laboratorial e informações relativas a fatores de risco para hepatites (SHAPIRO 1992, CDC 2000). Mesmo conduzindo esses dois sistemas, o CDC encontra dificuldades para detectar as mudanças na tendência da incidência da doença e identificar fatores de risco, devido à a baixa sensibilidade do sistema e falta de integralidade dos dados obtidos pela investigação epidemiológica e laboratorial (BELL e col. 1998).

Em 1982, foi implantado um terceiro sistema de vigilância em condados sentilenas (em uma amostra representativa das unidades locais de saúde). Nesses condados desenvolvem-se estudos mais aprofundados identificar mudanças nos caracteres epidemiológicos dos diferentes tipos de hepatite, complementando as informações da vigilância nacional, alem disso, têm sido utilizados para detectar infecções emergentes (CDC 2000). Trata-se de um sistema passivo, como os outros dois os outros dois já citado, diferindo desses por incluir na confirmação de caso a pesquisa de todos marcadores das hepatites virais e por investigar extenso elenco de fatores de risco para essas infecções. Estudos realizados nesses condados têm dado importante contribuição à descrição da epidemiologia e da história natural da hepatite C, além de demonstrarem a importância do VHC como causa de doença do fígado, crônica ou aguda (CDC 1998).

Na Itália, as hepatites A, B, C e D estão sob vigilância desde 1984. O Sistema Epidemiológico Integrado das Hepatites Virais Agudas - SEIEVA é coordenado pelo Istituto Superiore di Sanitá em colaboração com as unidades locais de saúde. Em 1996, 129 unidades participavam do SEIEVA, abrangendo aproximadamente $46 \%$ da população italiana. É um sistema do tipo passivo, que fundamenta-se na notificação semanal dos casos e na utilização de uma ficha de notificação com informações a respeito dos fatores de risco para as hepatites. A definição de caso utiliza critérios clínicos e laboratoriais (MELE e col. 1986; STROFFOLINI e col. 1997; MELE e col. 2000).

$\mathrm{Na}$ França, a vigilância das hepatites virais é realizada por uma rede sentinela de 500 médicos voluntários que comunicam os casos identificados não só de 
hepatites, mas de outras 6 doenças, por via eletrônica. Para cada caso, é preenchido uma ficha de notificação. A rede de médicos sentinela representa uma maneira rápida de registro de casos, que são compilados e analisados semanalmente, permitindo que epidemias possam ser detectadas e localizadas com precisão. O ponto vulnerável deste tipo de vigilância está nos próprios médicos que não notificam os casos com a agilidade necessária, interferindo desfavoravelmente na sensibilidade e representatividade do sistema (CHAUVIN 1994, FOURQUET e DRUCKER 1997).

\section{VIGILÂNCIA DAS HEPATITES VIRAIS NO BRASIL}

Na década de 80, o desenvolvimento de vacinas eficazes contra hepatite B e os estudos para elaboração da vacina contra a hepatite A levaram à reformulação das prioridades para o controle das hepatites em nível mundial. Diante dessa perspectiva, a Organização Mundial da Saúde - OMS convocou um grupo técnico assessor com a finalidade de estabelecer um programa de controle das hepatites virais. Esse grupo, em reuniões realizadas em 1984 e 1985, apontou vários campos de importância nos quais seria preciso atuar, entre eles: a produção regional de vacinas como meio de reduzir seu custo; o estabelecimento de programas regionais de controle da hepatite B; a realização de investigações eficazes em epidemiologia das hepatites e das estratégias pertinentes à imunização contra a hepatite B (HADLER e col. 1987).

Atendendo às recomendações do Grupo Técnico Assessor da OMS, a Organização Pan-americana da Saúde (OPAS) convocou um comitê ad hoc para discutir as hepatites virais nas Américas, que se reuniu em maio de 1985, no Rio de Janeiro (HADLER e col. 1987). Como conseqüência das recomendações desse grupo, foi criada no Brasil a Comissão Nacional de Hepatites que começou a estruturar o sistema de vigilância no país. No entanto, um sistema de vigilância das hepatites virais somente foi implantado em nosso meio na década de 90. Apesar das dificuldades para a sua operacionalização, esse sistema permitiu a obtenção de informações que subsidiaram a elaboração da estratégia de vacinação contra hepatite B no país. Ainda assim, permanecem várias lacunas no conhecimento a respeito da ocorrência destas infecções em nosso meio, pois a adesão das unidades federadas não 
tem sido homogênea, gerando limitações importantes no sistema de informação (FUNASA $2001^{1}$ ).

Inicialmente esse sistema abrangia todas as hepatites virais, porém em 1998, houve uma solução de continuidade desse sistema que, no entanto, foi reativado no ano seguinte com a inclusão das hepatites B e da C (TEIXEIRA e col. 1998; GAZE e col. 2000).

Em São Paulo, a emergência das hepatites como problema de saúde pública ocorreu na década de 50, como assinalou ESCRIVÃO (1985) fundamentado numa extensa revisão histórica do controle das doenças transmissíveis no Estado. Este trabalho representa uma primeira abordagem do problema de hepatite, ressaltando a importância da doença em termos de morbidade e mortalidade ao analisar o papel das instituições pela produção de dados, informações e execução de programas.

As hepatites virais não foram incluídas no Sistema de Vigilância de São Paulo, criado na segunda metade da década de 70. Em 1985, a notificação e a investigação de surtos epidêmicos de hepatite A tornou-se obrigatória, permanecendo nessa condição até os dias atuais (PERRENOUD 1995). Entretanto, a reformulação do modelo atual de vigilância das hepatites do Estado tornou-se relevante, pois esse sistema não contempla as hepatites $\mathrm{B}$ e $\mathrm{C}$ e, mesmo decorridos mais de 15 anos da implantação da notificação compulsória das epidemias de hepatite A, o conhecimento obtido sobre a epidemiologia dessa infecção ainda é insuficiente para fundamentar a elaboração de estratégias de prevenção e controle específicas para o Estado de São Paulo.

O Sistema de Vigilância das Hepatites Virais no Estado de São Paulo, abrangendo neste momento as hepatites A, B e C, está em fase de reestruturação sendo que com tal objetivo já foi elaborado e distribuído seu manual, estão sendo identificados os Centros de Referência de Diagnóstico e Tratamento e padronizadas as informações que serão enviadas pelos Centros, o que permitirá a elaboração do fluxograma do Sistema. A medida que este sistema esteja completamente implantado, será incorporadoà sua rotina a investigação epidemiológica dos casos de hepatite B e C, estudos de soroprevalência das hepatites A e E e de prevalência de

\footnotetext{
${ }^{1}$ FUNASA - CENEPI Versão preliminar da proposta de restruturação da vigilância epidemiológica das hepatites. abril/2001 (documento não publicado)
} 
VHB mutante e dos subtipos de VHC. Este sistema deverá ser continuamente reavaliado, inclusive quanto a necessidade de notificar todas as hepatites virais, incluindo-as na lista das Doenças de Notificação Compulsória do Estado de São Paulo (CVE 2000)

\section{A EXPERIÊNCIA DE VARGEM GRANDE PAULISTA}

$\mathrm{Na}$ época do planejamento e da implantação do sistema de vigilância em Vargem Grande Paulista, a Faculdade de Saúde Pública desenvolvia no Município, há vários anos, um projeto voltado à organização da sociedade civil, buscando ampliar a consciência e a participação da comunidade na resolução de seus problemas, para melhorar as suas condições de saúde. Acredita-se que o envolvimento da população com esse projeto seria um fator propício à adesão da comunidade ao sistema. Outro aspecto que contribuiu para escolha do município é que os Serviços de Saúde do Município estavam bem estruturados, principalmente ao nível primário. E, finalmente, o Município apresenta características que são semelhantes às outras áreas periféricas da capital e dos demais municípios que compõem a área metropolitana de São Paulo, ou seja, apresentam população constituída, em boa parte, por indivíduos de baixa renda e migrantes.

O planejamento de um sistema de vigilância começa com a definição de seus objetivos e, é importante ressaltar que vão além da simples coleta e análise de informações. O principal objetivo do sistema de vigilância implantado em Vargem Grande Paulista foi fornecer subsídios para elaboração de estratégias de prevenção e controle das hepatites $\mathrm{A}, \mathrm{B}$ e melhor conhecer as hepatites $\mathrm{C}$ e $\mathrm{E}$ para quando medidas específicas em relação as mesmas estejam disponíveis. Deve-se entender que a prevenção tem um caráter amplo e inclui, não apenas, a prevenção de doenças (prevenção primária), mas a detecção precoce e intervenção para reverter, cessar ou pelo menos retardar o progresso de uma condição (prevenção secundária) e a diminuição dos efeitos da doença entre aqueles que já estão doentes (prevenção terciária) (CDC 1988).

A segunda etapa da elaboração de um sistema de vigilância é a definição de caso. É uma questão técnica fundamental para garantir a qualidade da informação, permitindo que casos identificados em diferentes lugares e períodos possam ser 
classificados e comparados adequadamente. A definição de casos está intimamente relacionada aos objetivos do sistema (SACKS 1985; TEUTSCH 1994; WALDMAN 1998).

O sistema de vigilância de Vargem Grande Paulista utilizou duas definições de caso, uma para caso suspeito e outra para caso confirmado. A primeira mais sensível, fundamentada em critérios clínicos, epidemiológicos e laboratoriais, e a segunda mais específica, baseada na detecção dos marcadores das hepatites virais. Essa estratégia aumentou a capacidade do sistema em identificar os casos de hepatite $\mathrm{A}, \mathrm{B}, \mathrm{C}$ ou $\mathrm{E}$, ao mesmo tempo que reduziu o número de casos falsamente positivos.

A terceira etapa refere-se à elaboração do fluxograma, ou seja, a identificação dos principais passos seguidos pelo sistema de vigilância. Uma das principais preocupações no planejamento do sistema de vigilância de Vargem Grande Paulista foi estruturá-lo o mais simples possível, de forma a adequar-se à realidade dos Serviços de Saúde do Município, visando a continuidade da experiência após o término do projeto.

A última etapa do planejamento de um sistema de vigilância consiste na identificação de seus componentes. Cabe ressaltar que os sistemas de vigilância devem apresentar três componentes que são aceitos internacionalmente: coleta de dados, análise e ampla distribuição das informações analisadas a todos aqueles que as geraram e que delas necessitam tomar conhecimento (WALDMAN 1991). A devolução da informação analisada é fundamental para que as pessoas envolvidas mantenham-se informadas e motivadas, assegurando a credibilidade do sistema.

Na experiência de Vargem Grande Paulista não foi possível implantar esse último componente, restringindo-se a pequenos relatórios que eram enviados esporadicamente à equipe de vigilância, o que pode ter interferido na adesão dos médicos e profissionais da saúde à notificação sistemática dos casos e na qualidade do preenchimento das fichas de notificação.

De modo geral, a qualidade do preenchimento das fichas relativas ao inquérito efetuado entre as gestantes foi pior do que as dos casos suspeitos, chegando a comprometer a análise de algumas variáveis. Esse fato sugere que os médicos do Serviço Pré-natal estavam menos motivados com o projeto, do que os médicos dos Ambulatórios. 
Outro aspecto que deve ser abordado no desenvolvimento de um sistema de vigilância é a identificação das fontes de informação. Pode se optar por sistemas ativos ou passivos, dependendo das características do agravo, dos objetivos do sistema e dos recursos disponíveis. Os sistemas passivos caracterizam-se pela notificação espontânea dos casos, realizada por médicos e outros profissionais de saúde, hospitais e laboratórios. É o método mais utilizado por apresentar menor custo e maior simplicidade, porém são mais vulneráveis à sub-notificação do que os sistemas ativos. (THACKER e col. 1988; WALDMAN 1991).

Os sistemas ativos de vigilância requerem um contato direto, a intervalos regulares, entre os departamentos de saúde e as fontes de informação. Esse tipo de sistema permite o melhor conhecimento do comportamento da doença na comunidade, entretanto são mais dispendiosos que os do tipo passivo, além de necessitarem de uma infra-estrutura melhor dos serviços de saúde (WALDMAN 1991).

No sistema de vigilância implantado em Vargem Grande Paulista optou-se pelo tipo passivo, entretanto para melhorar o desempenho do sistema em identificar casos de hepatite viral, a equipe de vigilância realizou a revisão diária dos pedidos de exames verificando se todos os pacientes que tiveram solicitação das provas de função hepática foram notificados como casos suspeitos de hepatite viral.

Alguns estudos têm demonstrado que, mesmo para doenças comuns em países desenvolvidos a proporção de casos notificados pode variar de $10 \%$ a $63 \%$ dos casos realmente ocorridos na comunidade. Além disso, em determinadas doenças infecciosas cujo agente etiológico apresenta baixa patogenicidade, como é o caso da hepatite A, a infecção geralmente não é diagnosticada, ampliando a sub-notificação (MARIER 1977; THACKER e col. 1988; WALDMAN 1991).

No início da década de 1980, VOGT e col. (1983) ao comparar sistemas ativos e passivos de vigilância de hepatite, sarampo, rubéola e salmoneloses em Vermont, EUA, observaram que a vigilância ativa detectou maior números de casos, além de fornecer dados com melhor qualidade. 


\section{SOROPREVALÊNCIA DE MARCADORES DE HEPATITES VIRAIS DE GESTANTES NO SISTEMA DE VIGILÂNCIA}

Outro ponto que deve ser discutido na experiência de Vargem Grande Paulista é a inclusão das gestantes, como população sentinela. As hepatites virais apresentam uma grande proporção de casos inaparentes, o que dificulta o acompanhamento dessas infecções pelos sistemas tradicionais de vigilância, tornando-se necessário a identificação de estratégias alternativas para complementar as informações da vigilância.

Os inquéritos populacionais de soroprevalência permitem a análise e comparação dos resultados, representando uma das melhores alternativas para o conhecimento da frequiência e distribuição das hepatites virais, bem como para a identificação dos suscetíveis. Entretanto, apresentam alto custo operacional, além de enfrentarem uma série de dificuldades operacionais e éticas, como a de obter amostra de sangue de indivíduos sadios.

Foram identificadas na literatura algumas alternativas mais simples, de menor custo e mais aceitáveis pela população do que os inquéritos populacionais, ainda que percam em representatividade para esses.

Amostras de doadores de sangue parecem ser uma alternativa privilegiada para os estudos de prevalência das hepatites virais, pois um grande contingente de indivíduos é submetido a triagem laboratorial de rotina. Entretanto, a interpretação dos dados de banco de sangue deve considerar, que se trata de uma amostra relativamente selecionada, por ser constituída basicamente de adultos do sexo masculino e previamente auto selecionada do ponto de vista de morbidade (ANDRADE e col. 1989; MARTELLI e col. 1991).

MIRANDA e col. (2000) utilizaram amostras de soro excedente de pacientes que já estavam se submetendo a coleta de sangue por qualquer razão em unidades de saúde de Ribeirão Preto. Encontraram valores de prevalência de hepatite B próximos a dos doadores de sangue da região. GAZE e col. (2000) propuseram a utilização de um sistema de laboratórios sentinelas como método de monitoramento das hepatites A e B, empregando amostras de soro excedente de laboratório de análises clínicas. Para tanto os autores avaliaram os resultados de uma pesquisa de soroprevalência de 
VHA e VHB em Macaé, Rio de Janeiro, verificando a consistência dos valores encontrados, diante da realidade local e de dados da literatura. Concluíram que esta metodologia apresenta menor custo que os inquéritos soroepidemiológicos e sensibilidade adequada para o acompanhamento das infecções pelo VHA e VHB, possibilitando o gerenciamento de programas de prevenção, porém apresentam a desvantagem a limitação de não lidar com a totalidade dos serviços de saúde.

$\mathrm{Na}$ tentativa de obter uma estimativa melhor da prevalência das hepatites virais na população adulta em geral, vários autores têm utilizado amostras de gestantes em seus estudos. Das alternativas apresentadas, essa é uma das que apresenta mais vantagens, pois se trata de uma população relativamente pouco selecionada, de fácil acesso e de baixo custo operacional (BALDO e col. 2000).

Em Vargem Grande Paulista, os resultados do estudo de prevalência nas gestantes devem refletir a prevalência das hepatites $\mathrm{A}, \mathrm{B}, \mathrm{C}$ e E na população, principalmente considerando a boa cobertura do Serviço de Pré-natal (próxima dos 90\%) e o baixo índice de recusa em participar do estudo.

\section{ANÁLISE DOS DADOS GERADOS PELO SISTEMA DE VIGILÂNCIA DAS HEPATITES VIRAIS EM VARGEM GRANDE PAULISTA}

Dos casos de hepatite aguda com etiologia viral confirmada, 73,1\% foram atribuídos ao VHA. A maior parte dos casos de hepatite A ocorreram entre indivíduos jovens, 86,6\% tinham menos de 20 anos, com grande proporção de assintomáticos. Esse achado é consistente com a literatura, que descreve que a infecção é na maioria das vezes adquirida na infância, e mesmo nos países mais desenvolvidos, cerca de $50 \%$ dos casos de hepatite A envolvem pacientes com menos de 15 anos (CARRILHO e SILVA 1995; CDC 1996, CDC 1999).

A prevalência de hepatite A na população de gestantes estudada, acima dos 90\%, encontrada em Vargem Grande Paulista já era esperada, uma vez que as precárias condições de saneamento do município propiciam a disseminação do VHA: um vírus extremamente estável no ambiente e transmitido principalmente por via fecal-oral, pela ingestão de água ou alimento contaminado ou por transmissão pessoa a pessoa (WHO 1995; SILVA e MADRUGA 1996; KOFF 1998). 
O município apresenta características típicas das áreas de alta endemicidade de hepatite A, encontradas em países em desenvolvimento, particularmente nos países tropicais onde vírus pode ser hiperendêmico: 63,3\% dos casos de hepatite A aguda tinha menos de 10 anos e a soroprevalência em gestantes foi de $94,7 \%$ (GUST 1992; WHO 1995; CATTON e LOCARNINI 1998).

A soroprevalência de anticorpos contra o VHA aumentou com a idade, conforme vem sendo descrito na literatura (CDC 1999; GAZE e col. 2000). A prevalência geral de hepatite A para o município de São Paulo foi de 66,59\%, sendo que para os indivíduos menores de 18 anos foi de $34,35 \%$ e para os maiores de 83,35\% (FOCACCIA e col. 1998).

Esse dado é semelhante a de regiões com condições saneamento e higiene precários e população de baixo nível sócio-econômico. TAPIA-CONYER e col. (1999) encontraram prevalência de 89\% na República Dominicana, 81\% no México, 64,7\% no Brasil, 58,1\% no Chile, 55,7\% na Venezuela, 55\% na Argentina. As amostras do Brasil eram provenientes do Rio de Janeiro, Manaus, Porto Alegre e Fortaleza, cidades com condições sanitárias bastante heterogêneas. CLEMENS e col. (2000), em continuidade a esse estudo, encontraram prevalências de hepatite A variando de 55,7 \% no Rio de Janeiro e Porto Alegre a 92,8\% em Manaus.

PANNUTI e col., em 1985, analisaram amostras de soro de crianças e adultos de São Paulo e encontraram freqüências de anti-VHA variando com o nível sócioeconômico, sobretudo na infância. A prevalência de anticorpos anti-VHA no grupo de baixo nível sócio-econômico foi de 75\% entre as crianças de 2 a 11 anos e 100\% nos adultos, enquanto que no nível sócio-econômico mais alto a prevalência fora de 40,3\% e entre as crianças e de $91,9 \%$ entre os adultos. A prevalência entre doadores de sangue foi de 90,4\%. Em 1998, PINHO e col. em trabalho semelhante ao anterior, encontrou prevalência de 19,6\% entre estudantes de medicina, representando o nível sócio-econômico alto e de $95 \%$ entre doadores de sangue representando o nível sócio-econômico baixo.

Com o objetivo de avaliar o impacto das melhorias nas condições sanitárias na cidade do Rio de Janeiro, VITRAL e col. (1998) comparam a prevalência de hepatite A em dois grupos de crianças e adolescentes de baixo nível sócioeconômico, com amostras colhidas em 1978 e 1995. No primeiro grupo, as amostras 
foram colhidas em 1978, e no segundo em 1995. As prevalências foram 65,6\%, e $32,1 \%$, respectivamente.

Os trabalhos revistos indicam que a melhoria das condições sócio-econômicas e de saneamento contribui para a queda dos níveis de prevalência da hepatite A.

Os poucos casos confirmados de hepatite B, C e E não permitem análise mais apurada em relação a incidência dessas infecções no município.

As baixas prevalências de HBsAg $(0,1 \%)$ e de anti-HBc (4,9\%) encontradas nas gestantes, indicam que o Município é uma área de baixa endemicidade para o vírus da hepatite B, de acordo com os critérios definidos pela Organização Mundial da Saúde para classificação das regiões do mundo por prevalência dos marcadores da hepatite B (MARGOLIS 1991; SOUTO 1999).

A prevalência de hepatite B foi similar a observada em outros estudos realizados nas regiões Sul e Sudeste do país. (SABINO e col. 1992; DUARTE e col. 1997; CARRILHO e CORRÊA 1998; FOCACCIA e col. 1998; ANDRADE e col. 1999; MIRANDA e col. 2000; REICHE e col. 2000).

No entanto, os marcadores da hepatite B apresentam grande variação da prevalência, mesmo em localidades vizinhas. Essas diferenças podem ser explicadas por complexas relações entre seus fatores determinantes: condições sócioeconômicas, migração, características genéticas e nível de exposição ao vírus (SOUTO 1999a). Essa diversidade foi bem caracterizada em estudo conduzido por CLEMENS e col. (2000) que observou prevalência geral de 7,9\%, sendo que para a região Nordeste foi de 1,2\%, para Sudeste 5,5\%, para Sul 7,2\% e para Norte 21,4\%.

No Brasil os dados mais abrangentes de hepatites B e C são fornecidos pelos serviços de banco de sangue e ainda que se tratem de dados secundários, podem estimar a prevalência dessas infecções na população. Para a região Sudeste, os relatórios da Hemorrede Pública de 1997 e 1999 trazem, valores de prevalência de HBsAg $(0,58 \%$ e $0,33 \%$, respectivamente), anti-HBc $(5,40 \%$ e $4,01 \%)$ e anti-VHC $(1,35 \%$ e $1,01 \%)$ muito próximos aos encontrados em Vargem Grande Paulista (ANVISA 2001).

A principal via de transmissão do VHC é a parenteral (PURCELL 1997, CDC 1998, STRAUSS 2001). Provavelmente essa foi a via pela qual os casos de hepatite $\mathrm{C}$ detectados pelo sistema de vigilância de foram infectados, pois esses indivíduos 
receberam sangue quando ainda não era obrigatória a pesquisa do anti-VHC em banco de sangue. Só em 19 de novembro de 1993, a portaria n 1.376 do Ministério da Saúde tornou obrigatória a realização de testes para hepatite B e C na triagem de banco de sangue.

Muitos estudos registram a prevalência de anti-VHC entre doadores de sangue, entretanto a prevalência nesse grupo pode estar superestimada, uma vez que alguns bancos de sangue não utilizam um teste confirmatório para as amostras positivas pelo ELISA (TANNO e FAY 1999). Em Vargem Grande Paulista, as amostras que foram positivas para o ELISA, foram retestadas pelo immunoblot, diminuindo a possibilidade de resultados falsamente positivos.

A Sociedade Brasileira de Hepatologia realizou um inquérito em 27 Hemocentros oficiais de todo país e encontrou prevalência de hepatite $\mathrm{C}$ no Brasil de $1,23 \%$, variando de $0,6 \%$ na região Sul a $2,1 \%$ na região Norte. (FONSECA e col. 1999)

No estudo realizado em Londrina a prevalência de anti-VHC em gestantes foi de $0,8 \%$ inferior à detectada em candidatos a doadores de sangue $(1,2 \%)$ do Hemocentro de Londrina, no mesmo período (REICHE e col. 2000).

Os poucos estudos de soroprevalência de hepatite E demonstraram sua existência no Brasil, entretanto não há descrição de casos agudos (FOCACCIA e col. 1995; PANG e col. 1995; PARANA e col. 1997; SOUTO e col. 1997; FOCACCIA e col. 1998; GONÇALES e col. 2000; TRINTA e col. 2001). Os três casos de hepatite E aguda (presença de anti-VHE IgM) detectados em Vargem Grande Paulista são possivelmente os primeiros descritos no país.

A prevalência de anti-VHE IgG foi mais baixa que a esperada, considerando que a hepatite E é uma infecção de transmissão oral-fecal, assim como a hepatite A. Essa disparidade das prevalências das hepatites A e E encontrada em Vargem Grande Paulista, também foi relatada por TRINTA e col. (2001) em estudo realizado com diferentes populações do Rio de Janeiro. Esse grupo encontrou 1\% de prevalência de anti-VHE nas gestantes, 2,1\% em pacientes com hepatite NANBNC, 2,1\% em residentes em área rural, 4,3\% em doadores de sangue, 6,2\% em hemodialisados e 11,8\% em usuários de drogas ilícitas, enquanto que a prevalência de anti-VHA foi superior a $80 \%$ em todos grupos. 
Estudo semelhante realizado em Campinas, a prevalência de anti-VHE variou de $2,6 \%$ em profissionais da saúde a $17,7 \%$ em mulheres que se julgam grupo de risco para o HIV. Para os doadores de sangue, houve diferença entre os que tinham níveis de ALT normal e elevado, 3,0\% e 7,5\%, respectivamente (GONÇALES e col. 2000).

Segundo ARIF e col. (1994) alguns aspectos devem ser considerados ao avaliar a prevalência da hepatite E: o vírus é excretado em baixas concentrações o que pode restringir a disseminação do vírus; não está bem estabelecida a persistência dos anticorpos anti-VHE IgG e os testes disponíveis para a detecção desse anticorpos apresentam problemas de sensibilidade e especificidade.

\section{ALGUNS ASPECTOS DO DESEMPENHO DO SISTEMA de VIGILÂNCIA DAS HEPATITES VIRAIS}

Ainda que não tenha sido objetivo deste trabalho analisar o sistema de vigilância implantado, pois demandaria uma metodologia específica para essa finalidade, é oportuna a discussão de alguns indicadores do seu desempenho como a utilidade, sensibilidade, aceitabilidade, oportunidade e representatividade.

A avaliação da utilidade do sistema pode ser feita por duas abordagens. Uma diz respeito à capacidade do sistema em gerar conhecimentos que aprimorem a compreensão do agravo que esta sob vigilância e que fundamentem o desenvolvimento de estratégias de prevenção e controle.

O sistema de vigilância das hepatites implantado em Vargem Grande Paulista cumpriu os objetivos a que se propôs, permitindo identificar tendências no comportamento das hepatites A, B, C e E no Município.

Outra abordagem da utilidade, refere-se ao impacto que um sistema determina no estabelecimento de políticas, de medidas de intervenção ou mesmo, a sua influência na modificação do comportamento de um particular evento adverso à saúde (CDC 1988, WALDMAN 1991). Verificando a utilidade do sistema por esse lado, alguns pontos merecem ser destacados.

Durante o período de manutenção do sistema, foi realizada a pesquisa do HBsAg em todas as gestantes que participaram do estudo. Todas tiveram acesso aos resultados. A única gestante portadora de HBsAg foi acompanhada e orientada para 
que, na ocasião do parto, o recém-nascido recebesse, além da vacina contra hepatite B, a imunoglobulina humana. Esse procedimento foi incorporado a rotina de prénatal do Município.

Quando foram constatados casos de hepatite aguda B e C sugeriu-se o seguimento sorológico para avaliar a evolução dos marcadores. Os casos crônicos foram encaminhados ao Grupo de Hepatologia do Hospital das Clínicas da Faculdade de Medicina da Universidade de São Paulo. Com isso, o Município conseguiu uma referência de nível terciário para o tratamento das hepatites $\mathrm{B}$ e $\mathrm{C}$.

Como grande parte dos pacientes com hepatite aguda estavam fisicamente bem, podem não ter valorizado a doença e por isso alguns não fizeram o seguimento sorológico sugerido. Isso também poderia explicar o fato que dos 8 pacientes com hepatite crônica encaminhados, apenas 2 seguiram o tratamento do Hospital das Clínicas. Não pode ser descartada a possibilidade de que tenham procurado outro serviço.

A implantação do sistema de vigilância proporcionou aos profissionais envolvidos com o projeto a oportunidade de reciclagem de seu conhecimento em diagnóstico clínico, epidemiológico e laboratorial das hepatites virais. O projeto tornou rotina o diagnóstico etiológico das hepatites A, B e C no Município.

A Equipe local de vigilância sanitária tem utilizado os dados de hepatite A gerados pelo sistema como subsídio para discutir a situação do saneamento básico junto à Secretaria de Obras do Município e a SABESP.

A sensibilidade pode ser avaliada pela capacidade do sistema de vigilância em identificar casos de um determinado agravo, incluindo sua habilidade em detectar epidemias.

Foram detectados 125 casos suspeitos de hepatite viral, dos quais 41 (32,8\%) foram confirmados como hepatite A, B, C ou E. A definição de caso suspeito utilizada pelo sistema foi muito ampla, fundamentada em critérios clínicos, epidemiológicos e laboratoriais, o que pode explicar a baixa proporção de confirmação de casos. Se a exemplo de alguns sistemas de vigilância das hepatites aplicados em outros países (CDC 1990, CDC 2000; MELE e col. 1997; MELE e col. 2000), fossem considerados suspeitos apenas os indivíduos com sintomas típicos de hepatite ou com 
níveis elevados de transaminases, a proporção passaria para 58\%. Entretanto, o sistema não teria detectado $75 \%$ dos casos de hepatite $C$ que detectou.

O sistema de vigilância detectou um surto epidêmico de hepatite A no Bairro de Tijuco Preto. Acredita-se que as proporções desse surto estejam sub-estimadas, porque que nem todas as solicitações de coleta de sangue para pesquisa de anti-VHA IgM foram atendidas e, algumas só foram atendidas meses após terem sido feitas, quando o anti-VHA IgM poderia não estar mais detectável no soro.

A aceitabilidade de um sistema pode ser medida em função do nível de participação e rapidez do fluxo de informações; pela integralidade com que as questões existentes na ficha de notificação são respondidas e pela proporção de recusa da resposta a determinadas questões e ainda pela oportunidade da notificação.

A participação dos médicos e demais profissionais de saúde é um ponto crítico na qualidade da coleta de dados; portanto, o esclarecimento dessas equipes, salientando a importância da notificação de doenças para o aprimoramento dos serviços de assistência a saúde, deve ser prioritário nos programas de treinamento e formação de recursos humanos para esse campo de atividades (WALDMAN 1991).

A oportunidade reflete a agilidade do sistema em cumprir todas as suas etapas, desde a notificação dos casos até a distribuição dos boletins epidemiológicos. Esse atributo foi comprometido pela demora do envio das amostras a São Paulo e na devolução do resultado ao paciente.

Um sistema de vigilância representativo descreve com exatidão a ocorrência de um evento adverso à saúde ao longo do tempo, segundo as características da população e da distribuição espacial dos casos. A representatividade do sistema de Vargem Grande Paulista foi comprometida por alguns fatores como a procura dos serviços de saúde de outros municípios. A baixa representatividade de um sistema de vigilância pode resultar da falta de homogeneidade da subnotificação, dificultando a identificação de tendências, grupos e fatores de risco.

Em resumo pode-se afirmar que o sistema de vigilância implantado em Vargem Grande Paulista, mesmo apresentando algumas limitações, foi simples, útil e de custo relativamente baixo, sendo que vários procedimentos implantados durante $o$ desenvolvimento deste trabalho foram incorporados à rotina dos Serviços de Saúde do Município. Considerando que essa experiência desenvolveu-se nas condições 
normais de trabalho do serviço municipal de saúde de Vargem Grande Paulista, nos parece legítimo esperar que seus resultados contribuirão para a discussão da vigilância das hepatites virais no Estado de São Paulo. 


\section{REFERÊNCIAS}

Almeida LM. Soroprevalência da hepatite A: um possível parâmetro para mensuração de efeitos de intervenções ambientais sobre a saúde. Rio de Janeiro; 1997. [Dissertação de Mestrado - Instituto de Medicina Social da UERJ].

Alter MJ, Gallagher M, Morris TT, Moyer LA, Meeks EL, Krawczynski K et al. Acute non-A-E in the United States and the role of hepatitis G virus infection. N Engl J Med 1997; 336: 741-6.

Alves VAF, Gayotto LCC. Patologia das hepatites. In: Silva LC. Hepatites agudas e crônicas. $2^{\text {a }}$ ed. São Paulo: Sarvier; 1995. p.40-55.

Andrade ALSS, Martelli CMT, Pinheiro ED, Santana CL, Borges FP, Zicker F. Rastreamento sorológico para doenças infecciosas em banco de sangue como indicador de morbidade populacional. Rev Saúde Pública 1989; 23(1): 20-5.

Andrade CA, Martins MVL, Costa JO, Ribeiro DA, Andrade AMC, Gonçalves RC et al. Soroprevalência do HIV-1/2, HTLV-I/II e hepatites B e C em parturientes da Maternidade Odete Valadares, Belo Horizonte, Minas Gerais. Rev Patol Trop 1999; 28(1): 41-8.

[ANVISA] Agência Nacional de Vigilância Sanitária. [on line] last rev. Disponível em http://www.anvisa.gov.br/correlatos/sangue/relatorio.htm [2001 Aug 03].

Arif M, Quattan L, Faleh F, Ramia S. Epidemiology of Hepatitis E virus (HEV) infection in Saudi Arabia. Ann Trop Med Parasitol 1994; 88: 163-8. 
Baldo V, Floreani A, Menegon T, Grella P, Paternoster DM, Trivello R. Hepatitis C virus, hepatitis B virus and human immunodeficiency virus infection in pregnant women in North-East Italy: a seroepidemiological study. Eur J Epidemiol 2000; 16: $87-91$.

Bell BP, Shapiro CN, Alter MJ, Moyer LA, Judson FN, Mottram K, et al. The diverse patterns of hepatitis A epidemiology in the United States - implications for vaccination strategies. J Infect Dis 1998; 178: 1579-84.

Benenson AS, editor. Control of communicable diseases in man. $16^{\text {th }}$ ed. Washington (DC): American Public Health Association; 1995. Viral hepatitis; p.21733.

Blumberg BS, Alter HJ, Visnich S. A "New" antigen in Leukemia sera. JAMA 1965; 191(7): 541-6.

Bull AR, Kimmance KJ, Parry JV, Perry KR. Investigation of an outbreak of hepatitis A simplified by salivary antibody testing. Epidem Inf 1989; 103: 371-6.

Bryan JP, Tsarev AS, Iqbal M, Ticehurst J, Emerson S, Ahmed A et al. Epidemic hepatitis E in Pakistan: Patterns of serologic response and evidence that antibody to hepatitis E virus protect against disease. J Infect Dis 1994; 170: 517-21.

Carrilho FJ, Silva LC. Epidemiologia. In: Silva LC. Hepatites agudas e crônicas. $2^{\text {a }}$ ed. São Paulo: Sarvier; 1995. p.73-95.

Carrilho FJ, Corrêa MCJM. Magnitude of hepatitis B and C in Latin America. In: Schinazi RF, Sommadossi JP, Thomas HC, editors. Therapies for Viral Hepatitis 1998. p.25-34. 
Catton MG, Locarnini SA. Hepatitis A: epidemiology. In: Zuckerman AJ, Thomas HC, editors. Viral hepatitis: Scientific basis and clinical management. $2^{\text {nd }}$ ed. London: Churchill Livingstone; 1998. p.29-41.

[CDC] Centers for Disease Control and Prevention. Changing patterns of groups at high risk for hepatitis B in the United States. MMWR Morb Mortal Wkly Rep 1988; 37 (28): 427-32, 437.

[CDC] Centers for Disease Control and Prevention Guidelines for evaluating surveillance system. MMWR Morb Mortal Wkly Rep 1988; 37 (S-5).

[CDC] Centers for Disease Control and Prevention. Case definitions for Public Health surveillance. MMWR Morb Mortal Wkly Rep 1990; 39 (RR-13): 17.

[CDC] Centers for Disease Control and Prevention. Hepatitis Branch Slides Set. [on line] last rev. 1995. available from http://www.cdc.gov/ncidod/diseases/hepatitis/slideset [2000 Abr 10].

[CDC] Centers for Disease Control and Prevention. Recommendations for prevention and control hepatitis $\mathrm{C}$ virus (HCV) infection and HCV-related chronic disease. MMWR Morb Mortal Wkly Rep 1998; 47 (RR-19).

[CDC] Centers for Disease Control and Prevention. Prevention of hepatitis A through active or passive immunization. Recommendations of the Advisory Committee on Immunization Practices (ACIP). MMWR Morb Mortal Wkly Rep 1999; 48 (RR12).

[CDC] Centers for Disease Control and Prevention. Hepatitis Surveillance Report No 57. Atlanta. 2000. 38p. 
[CDC] Centers for Disease Control and Prevention. Hepatitis Branch Home Page. [on line] last rev. 2000 Dec 15. available from http://www.cdc.gov/ncidod/diseases/hepatitis/index.htm [2000 Feb 19].

Chauvin P. Constitution and monitoring of an epidemiological surveillance network with sentinel general practitioners. Eur J Epidemiol 1994; 10: 477-9.

Choo Q-L, Kuo G, Weiner AJ, Overby LR, Bradley DW, Houghton M. Isolation of cDNA clone derived from a blood-borne non-A non-B viral hepatitis genome. Science 1989; 244: 359-62.

Clemens SAC, Fonseca JC, Azevedo T, Cavalcanti A, Silveira TR, Castilho MC et al. Soroprevalência para hepatite A e hepatite B em quatro centros no Brasil. Rev Soc Bras Med Trop 2000; 33(1): 1-10.

Cohen J. The scientific challenge of hepatitis C. Science 1999; 285: 26-30.

Cossart Y. TTV - a virus searching for disease. J Clin Virol 2000; 17: 1-3.

[CVE] Centro de Vigilância Epidemiológica Professor Alexandre Vranjac. Secretaria do Estado da Saúde de São Paulo. Manual de Vigilância Epidemiológica Hepatites Virais: Normas e instruções 2000 .

Dane DS, Cameron CH, Briggs M. Virus - like particles in serumof patients with Australia-antigen-associated hepatitis. Lancet 1970; 1: 695-8.

Dean AG, Dean JA, Coulombier D, Brendel KA, Smith DC, Burton AH et al. Epi Info, Version 6: a word processing database and statistics program for epidemiology on microcomputers [computer program]. [CDC] Centers of Disease of Control and Prevention, Atlanta; 1994. 
Decker RH. Diagnosis of acute and chronic hepatitis B. In: Zuckerman AJ, Thomas HC, editors. Viral hepatitis: Scientific basis and clinical management. $2^{\text {nd }}$ ed. London: Churchill Livingstone; 1998. p.201-15.

Di Bisceglie AM. Hepatitis C. Lancet 1998; 351: 351-5.

Di Bisceglie AM. Hepatitis B : Epidemiology and diagnosis. In: Zuckerman AJ, Thomas HC, editors. In: Viral hepatitis: Scientific basis and clinical management. $2^{\text {nd }}$ ed. London: Churchill Livingstone; 1998.p.371-8.

Duarte G, Mussi-Pinhata MM, Martinez R, Lemos C, Figueiredo EML, Quintana SM. Frequency of pregnant women with HBsAg in Brazilian community. Rev Panam Salud Pública 1997; 1(1): 35-40.

Escrivão Junior A. As práticas de controle das doenças transmissíveis: a questão da hepatite por vírus no Estado de São Paulo. São Paulo, 1985 [ Dissertação de Mestrado - Faculdade de Medicina da USP].

Evans AA, London WT. Epidemiology of hepatitis B. In: Zuckerman Viral hepatitis: Scientific basis and clinical management. $2^{\text {nd }}$ ed. London: Churchill Livingstone; 1998. p.107-14.

Fabris P, Biasin MR, Infantolino D, Tositti G, Venza E, Floreani A, et al. TTV infection in patients with acute hepatitis of defined aetiology and in acute non-A-E hepatitis. J Hepatol 2000; 32: 661-5.

Favorov MO, Fields HA, Purdy MA, Yashina TL, Aleksandrov AG, Alter MJ, et al. Serologic identification of hepatitis $\mathrm{E}$ virus infections in epidemic and endemic settings. J Med Virol 1992; 36: 246-50. 
Feinstone SM, Kapikian AZ, Purcell RH. Hepatitis A: Detection by immune electron microscopy of a viruslike antigen associated with acute illness. Science 1973; 182: 1026-8.

Ferraz MLG, Vilela MP, Silva AE, Paiva ER. Marcadores sorológicos do vírus da hepatite B e anticorpo delta em homossexuais masculinos brasileiros. Rev Paul Med 1985; 103 (5): 228-30 .

Focaccia R, Conceição OJG, Sette H, Sabino E, Bassit L, Nitrini DR et al. Estimated prevalence of viral hepatitis in the general population of the Municipality of São Paulo, measured by a serologic survey of a stratified, randomized and residencebased population. BJID 1998; 2 (6): 269-84.

Focaccia R, Conceição OJG. Quadro clínico das formas agudas benignas. In: Focaccia R, editor. Hepatites virais. São Paulo: Atheneu; 1997. p.3-6.

Fonseca JC, Brasil LM. Hepatite Delta. In: Silva LC. Hepatites agudas e crônicas. $2^{\mathrm{a}}$ ed. São Paulo: Sarvier; 1995. p.163-74.

Fonseca JF. Hepatite D. In: Focaccia R, editor. Hepatites virais. São Paulo: Atheneu; 1997.p.67-9.

Fonseca JC. Epidemiologia da infecção pelo vírus da hepatite C no Brasil - Relatório do grupo de estudo da Sociedade brasileira de Hepatologia. GED 1999; 18: S3-7.

Fourquet F, Drucker J. Communicable disease surveillance: the sentinel network. Lancet 1997; 349: 794-5.

Garson JA, Tedder RS, Briggs M, Tuke P, Glazebrook JA, Trute A et al. Detection of hepatitis $\mathrm{C}$ viral sequences in blood donations by "nested" polymerase chain reaction and prediction of infectivity. Lancet 1990a; 335: 1419-22. 
Garson JA, Tuke P, Makris M, Briggs M, Machin SJ, Preston FE et al. Detection of hepatitis $\mathrm{C}$ viral sequences in blood donations by "nested" polymerase chain reaction and prediction of infectivity. Lancet 1990b; 336: 1022-5.

Gaze R, Carvalho DM, Luiz RR, Servino VRR, Berro OJ, Bravin Y. Laboratórios sentinelas - uma proposta para o monitoramento das infecções pelos vírus das hepatites A e B. Informe Epidemiológico do SUS 2000; 9(1): 5-21.

Gonçales NSL, Pinho JRR, Moreira RC, Saraceni CP, Spina AMM, Stucchi RB et al. Hepatitis E immnoglobulin $\mathrm{G}$ antibodies in different populations in Campinas, Brazil. Clin Diagn Lab Immunol 2000; 7(5): 813-6.

Grob PJ. Hepatitis B: virus, pathogenesis and treatment. Vaccine 1998; 16 Suppl: S11-S16.

Gust ID. Epidemiological patterns of hepatitis A in the different parts of the world. Vaccine 1992; 10 Suppl 1: S56-S58.

Gust ID. Hepatitis A: diagnosis. In: Zuckerman AJ, Thomas HC, editors. Viral hepatitis: Scientific basis and clinical management. $2^{\text {nd }}$ ed. London: Churchill Livingstone; 1998. p.59-62.

Hadler SC, Fay OH, Pinheiro F, Maymard JE. La hepatitis en las Americas: informe del grupo colaborador de la OPS. Bol Of Sanit Panam 1987; 103(3): 185-206.

Hall AJ. Viral hepatitis: control, seroepidemiology and surveillance. Trans R Soc Trop Med Hyg 1996; 90: 1-2.

Harrison TJ. Hepatitis E virus: an update. Liver 1999; 19:171-6.

[HFI] Hepatitis Foundation International. Hepatitis statistics. [on line] last rev 1999 Feb. available from http://www.hepfi.org/infomenu.htm [2000 Feb 19]. 
Hollinger FB. Hepatitis B virus. In: Fields BN, Knipe DM, Howley PM, Chanock RM, Melnick, JL, Monath, TP, Roizman B, Straus SE, editors. Fields virology. $3^{\text {rd }}$ ed. Philadelphia: Lippincott-Raven Publishers; 1996. p.2738-802.

Hollinger FB, Ticehurst JR. Hepatitis A virus. In: Fields BN, Knipe DM, Howley PM, Chanock RM, Melnick JL, Monath, TP, Roizman B, Straus SE, editors. Fields virology. $3^{\text {rd }}$ ed. Philadelphia: Lippincott-Raven Publishers; 1996. p.735-82.

Hoofnagle JH, Tralka TS. National Institute of Health Consensus Development Conference Panel Statement: management of hepatitis C. Hepatology 1997; 26(3 Suppl 1): 2S-10S.

Houghton M. Hepatitis C viruses. In: Fields BN, Knipe DM, Howley PM, Chanock RM, Melnick, JL, Monath, TP, Roizman B, Straus SE, editors. Fields virology. $3^{\text {rd }}$ ed. Philadelphia: Lippincott-Raven Publishers; 1996. p.1035-56.

Kann M, Gerlich W. Hepatitis B virus: structure and molecular virology. In: Zuckerman AJ, Thomas HC, editors. Viral hepatitis: Scientific basis and clinical management. $2^{\text {nd }}$ ed. London: Churchill Livingstone; 1998. p.77-106.

Kato H, Mizokami M, Orito E, Ohno T, Hayashi K, Nakano T, et al. Lack of association between TTV viral load and aminotransferase levels in patients with hepatitis C or non-B-C. Scand J Infect Dis 2000; 32(3): 259-62

Knight V, Drake ME, Belben EA, Franklin BJ, Romer M, Copple LO. Characteristics of spread of infectious hepatitis in school and house hold epidemic in a rural area. Am J Hyg 1954; 59: 1-16.

Koff RS. Clinical manifestations and diagnosis of hepatitis A virus infection. Vaccine 1992; 10 Suppl 1: S15-S16.

Koff RS. Hepatitis A. Lancet 1998; 341: 1643-9. 
Krawczynski K, Mast EE. Hepatitis E: epidemiology, natural history and experimental models. In: Zuckerman AJ, Thomas HC, editors. Viral hepatitis: Scientific basis and clinical management. $2^{\text {nd }}$ ed. London: Churchill Livingstone; 1998. p.403-9.

Langmuir AD. The surveillance of communicable diseases of national importance. New Engl J Med 1963; 268(4): 182-92.

Langmuir AD. Evolution of the concept of surveillance in the United States. Proc Royal Soc Med 1971; 64: 681-4.

Linnen J, Wages J, Keck ZYZ, Fry KE, Krawczynski KZ, Alter H, et al. Molecular cloning and disease association of Hepatitis G Virus: A transfusion-transmissible agent. Science 1996; 271: 505-8.

Lok ASF, Gunaratnam NT. Diagnosis of hepatitis C. Hepatology 1997; 26 Suppl 1: 48S-56S.

Mahoney, FJ. Update on diagnosis, management, and prevention of hepatitis B virus infection. Clin Microbiol Rev 1999; 12: 351-66.

Margolis HS, Alter MJ, Hadler SC. Hepatitis B: envolving epidemiology and implications for control. Sem Liver Dis 1991; 2: 84-92.

Marier R. The reporting of communicable diseases. Am J Epidemiol 1977; 105: 58790.

Martelli CMT, Andrade ALSS, Cardoso DDP, Silva AS, Zicker F. Considerações metodológicas na interpretação do rastreamento sorológico da hepatite B em doadores de sangue. Rev Saúde Pública 1991; 25(1): 11-6. 
Mele A, Rosmini F, Zampieri A, Gill ON, and SEIEVA collaborating group. Integrated epidemiological system for acute viral hepatitis in Italy (SEIEVA): description and preliminary results. Eur J Epidemiol 1986; 2(4): 300-4.

Mele A, Strofflini T, Palumbo F, Gallo G, Ragni P, Balocchini E. Incidence of and risk factors for hepatitis A in Italy: public health indications from 10-year surveillance. J Hepatol 1997; 26: 743-7.

Mele A, Tosti ME, Marzolini A, Moiraghi A, Ragni P, Gallo G, Balocchini E et al. Prevention of hepatitis $\mathrm{C}$ in Italy: lessons from surveillance of type-specific acute viral hepatitis. J Viral Hepatitis 2000; 7: 30-5.

Melnick JL. Properties and classification hepatitis A virus. Vaccine 1992; 10 Suppl 1: S24-S26.

Miranda LVG, Passos ADC, Figueiredo JFC, Gaspar AMC, Yoshida CFT. Marcadores sorológicos de hepatite B em indivíduos submetidos a exames de sangue em unidades de saúde. Rev Saúde Pública 2000; 34(3): 286-91.

Nishizawa T, Okamoto H, Konishi K, Yoshizawa H, Miyakawa Y, Mayumi M. A novel DNA virus (TTV) associated with elevated transaminase levels in posttransfusion hepatitis of unknow etiology. Biochem Biophys Res Commun 1997; 241: 92-7.

Norder H, Hammas B, Löfdahl S, Couroucé AM, Magnius LO. Comparison of the amino acid sequences of nine different serotypes of hepatitis B surface antigen and genomic classification of the corresponding hepatitis B virus strain. J Gen Virol 1992; 73: 1201-8.

O'Grady J. Management of acute and fulminant hepatitis A. Vaccine 1992; 10 Suppl 1: $\mathrm{S} 21-\mathrm{S} 23$. 
Oba IT, Spina AMM, Saraceni CP, Lemos MF, Senhoras RCFA, Moreira RC, Granato CFH. Detection of hepatitis A antibodies by Elisa using saliva as clinical samples. Rev Inst Med trop S Paulo 2000; 42(4): 197-200.

Ochnio JJ, Scheifele DW, Ho M. Hepatitis A virus infection in urban children - are preventive opportunities being missed? J Infect Dis 1997; 176: 1610-3.

Okamoto H, Tsuda F, Sakugawa H, Sukugawa H, Sastrosoewignjo RI, Imai M, Miyakawa Y, Mayumi M. Typing hepatitis B virus by homology in nucleotide sequence: comparison of surface antigen subtypes. J Gen Virol 1988; 69: 2575-3.

Okamoto H, Nishizawa T, Kato N, Ukita M, Ikeda H, Iizuka H, et al. Molecular cloning and characterization of a novel DNA virus (TTV) associated with posttransfusion hepatitis of unknown etiology. Hepatology 1998; 10: 1-16.

Panda SK, Jameel S. Hepatitis E virus: from epidemiology to molecular biology. Viral Hepat Rev 1997; 3: 227-51.

Pang L, Alencar FEC, Cerutti C, Milhous WK, Andrade AL, Oliveira R et al. Short report: hepatitis E infection in the Brazilian Amazon. Am Trop Med Hyg 1995; 52(4): 347-8.

Pannuti CS, Mendonça JS, Carvalho MJM, Oselka GW, Amato Neto V. Hepatitis A antibodies in two socioeconomically distinct populations of São Paulo, Brazil. Rev Inst Med trop São Paulo 1985; 27(3): 162-4.

Paraná R. Estudo clínico sorológico da hepatite aguda não-A não-B esporádica em Salvador - Bahia. Salvador; 1997 [Tese de Doutorado - Faculdade de Medicina da Universidade Federal da Bahia].

Paraná R, Cotrim HP, Cortey-Boennec ML, Trepo C, Lyra L. Prevalence of hepatitis E virus $\operatorname{IgG}$ antibodies in patients from a referral unit of liver diseases in Salvador, Bahia, Brazil. Am Trop Med Hyg 1997; 5(1): 60-1. 
Perrenoud BAF. Mortes por hepatite viral aguda grave no município de São

Paulo: subsídio à vigilância epidemiológica. São Paulo; 1995. [Dissertação de Mestrado - Faculdade de Saúde Pública da USP].

Pinho JRR, Bassit L, Saez-Alquézar A. Estrutura dos vírus das hepatites. In: Silva LC. Hepatites agudas e crônicas. $2^{\mathrm{a}}$ ed. São Paulo: Sarvier; 1995. p.9-25.

Pinho JRR, Sumita LM, Moreira RC, Souza VAUF, Saraceni CP, Oba IT, et al. Duality of patterns in hepatitis A epidemiology: a study involving two socioeconomically distinct populations in Campinas, São Paulo State, Brazil. Rev Inst Med trop São Paulo 1998; 40(2): 105-6.

Pinho JRR, Takahashi DA, Fava ALB, Gonçales NSL, Carrilho FJ, Stucchi RSB, et al. Preliminary report. Transfusion-Transmitted Virus (TTV) in Brazil. Rev Inst Med trop São Paulo 1998; 40(5): 335-6.

Pinho JRR, Bernardini AP. Novos vírus associados com hepatites. NewsLab 1999; 35: 169-76.

Pinho JRR, Ferreira JLP, Fava A, Gonçales NSL, Saraceni CP, Moreira RC, et al. Hepatitis E Virus, GB Virus C and TT Virus among Brazilian Blood Donors with normal and raised ALT levels. J Hepatol 1999; 30(s1): 258.

Pinho JRR. Diagnóstico sorológico das hepatites virais. GED 1999; 18 Suppl 1: S13S15.

Pinho JRR, Silva LC. Hepatite G. In: Gayotto LCC, Alves VAF, editors. Doenças do Fígado e Vias Biliares. Atheneu; 2001. p. 507-14.

Purcell RH, Gerin JL. Hepatitis Delta virus. In: Fields BN, Knipe DM, Howley PM, Chanock RM, Melnick, JL, Monath, TP, Roizman B, Straus SE, editors. Fields virology. $3^{\text {rd }}$ ed. Philadelphia: Lippincott-Raven Publishers; 1996. p.2819-30. 
Purcell RH. Hepatitis E virus. In: Fields BN, Knipe DM, Howley PM, Chanock RM, Melnick, JL, Monath, TP, Roizman B, Straus SE, editors. Fields virology. $3^{\text {rd }}$ ed. Philadelphia: Lippincott-Raven Publisher; 1996. p.2831-44.

Purcell RH. The hepatitis C virus: overview. Hepatology 1997; 26 Suppl1: 11S-14S.

Reiche EMV, Morimoto HK, Farias GN, Hisatsugu KR, Geller L, Gomes ACLF, et al. Prevalência de tripanossomíase americana, sífilis, toxoplasmose, rubéola, hepatite B, hepatite C e da infecção pelo vírus da imunodeficiência humana, avaliada por intermédio de testes sorológicos, em gestantes atendidas no período de 1996 a 1998 no Hospital Universitário Regional Norte do Paraná (Universidade Estadual de Londrina, Paraná, Brasil). Rev Inst Bras Med Trop 2000; 33(6): 519-27.

Regev A, Schiff, ER. Viral hepatitis. Curr Opin Gastroenterol 1999; 15: 234-9.

Sabino EC, Guerra EM, Oba IT, Spina AMM, Vaz AJ. Frequência de marcadores de hepatite $\mathrm{B}$ em gestantes de primeira consulta em centros de saúde de área metropolitana, São Paulo, Brazil. Rev Inst Med trop São Paulo 1992; 34(6): 535-41.

Sacks JJ. Utilization of case definitions and laboratory reporting in the surveillance of notifiable communicable diseases in the United States. Am J Public Health 1985; 75:1420-2.

Santos VA, Azevedo RS, Camargo ME, Alves VAF. Effects of new evaluation of cutoff values for enzyme-linked immunosorbent assay in Brazilian patients. Am J Clin Pathol 1999; 112: 418-24.

Schafer DF, Sorrel MF. Hepatocellular carcinoma. Lancet 1999; 353:1253-7.

Schiff ER. Atypical clinical manifestations of hepatitis A. Vaccine 1992; 10 Suppl 1: S18-S20. 
[SEADE] Fundação Sistema Estadual de Análise de Dados. Informações dos municípios paulistas. [on line] disponível em http://www.seade.gov.br [2001 Feb 19].

Shapiro CN, Coleman PJ, McQuillan G, Alter MJ, Margolis HS. Epidemiology of hepatitis A: seroepidemiology and risk groups in the USA. Vaccine 1992; 10 Suppl 1: S59-62.

Sherlock S. Clinical features of hepatitis. In: Zuckerman AJ, Thomas HC, editors. Viral hepatitis: Scientific basis and clinical management. $2^{\text {nd }}$ ed. London: Churchill Livingstone; 1998. p.1-14.

Silva LC. Hepatites agudas e crônicas. $2^{a}$ ed. São Paulo: Sarvier; 1995a. Conceitos, tipos de hepatites por vírus e evolução dos conhecimentos; p.1-8.

Silva LC. Hepatites agudas e crônicas. $2^{\text {a }}$ ed. São Paulo: Sarvier; 1995b. Aspectos gerais clínicos, laboratoriais e diagnósticos; p.96-108.

Silva LC. Hepatites agudas e crônicas. $2^{a}$ ed. São Paulo: Sarvier; 1995c. Clínica e evolução das hepatites por vírus; p.109-17.

Silva LC, Madruga CLA. Aspectos peculiares e história natural da hepatite A. In: Silva LC. Hepatites agudas e crônicas. ${ }^{a}$ ed. São Paulo: Sarvier; 1995. p.137-42.

Simmonds P, Alberti A, Alter A, Alter HJ, Bonino F, Bradley DW, et al. A proposed system for the nomenclature of hepatitis C viral genotypes. Hepatology 1994; 19: $1321-4$.

Simons JN, Leary TP, Dawson GJ, Pilot-Matias TJ, Muerhoff AS, Schlauder GG, et al. Isolation of a novel virus-like sequences associated with human hepatitis. Nature Medicine 1995; 1(6): 564-9.

Skidmore SJ. Factors in spread of hepatitis E. Lancet 1999; 354: 1049-50. 
Sokal EM, Bortolotti F. Update on prevention and treatment in children. Curr Opin Pediatr 1999; 11: 384-9.

Souto FJD. Distribuição da hepatite B no Brasil: atualização do mapa epidemiológico e proposições para seu controle. GED 1999; 18(4): 143-150

Souto FJD, Fontes CJF, Martelli CMT, Turchi MD, Martins RMB, Andrade ALSS. Hepatitis $\mathrm{C}$ virus prevalence among an immigrant community to the Southern Amazon, Brazil. Mem Inst Oswaldo Cruz 1999; 94(6): 719-23.

Strauss E. Hepatite C. Rev Soc Bras Med Trop 2001; 34(1): 69-82.

Stroffolini T, Ferrigno L, Cialdea L, Catapano R, Palumbo F, Novaco F et al. Incidence and risk factors of acute Delta hepatitis in Italy: results from a national surveillance system. J Hepatol 1994; 21: 1123-6.

Stroffolini T, Ragni P, Moiraghi A, Balocchini E, Santonastasi F, Gallo G et al. Case fatality of acute hepatitis in Italy: results from a 10 year surveillance. Scand J Infect Dis 1997; 29: 87-9.

Stuyver L. Genótipos de VHC e métodos de genotipagem. NewsLab 1996; 15: $147-$ 52.

Tam AW, Bradley DW. Hepatitis E virus: structure and molecular virology. In: Zuckerman AJ, Thomas HC, editors. Viral hepatitis: Scientific basis and clinical management. $2^{\text {nd }}$ ed. London: Churchill Livingstone; 1998. p.395-402.

Tanaka E, Ohue C, Aoyagi K, Yamaguchi K, Yagi S, Kiyosawa K et al. Evaluation of a new enzime immunoassay for hepatits $\mathrm{C}$ virus (HCV) core antigen with a clinical sensitivity approximating that of genomic amplification of HCV RNA. Hepatology 2000; 32(2): 388-93. 
Tanaka Y, Primi D, Wang RYH, Umemura T, Yeo AET, Mizokami M, et al. Genomic and molecular evolutionary analysis of a newly identified infectious agent (SEN virus) and its relationship to the TT Virus family. J Infect Dis 2001; 183: 35967

Tanno H, Fay O. Viral hepatitis in Latin America. Viral Hepat Reviews 1999; 5 (1): 45-61.

Tapia-Conyer R, Santos JI, Cavalcanti AM, Urdeneta E, Rivera L, Manterola A, et al. Hepatitis A in Latin America: a changing epidemiologic pattern. Am J Trop Hyg 1999; 61(5): 825-9.

Taylor JM. Hepatitis Delta virus. Intervirology 1999; 42: 173-8.

Teixeira MG, Penna GO; Risi JB; Penna ML, Alvim MF, Moraes JC, Luna E. Seleção das doenças de notificação compulsória: critérios e recomendações para as três esferas do governo. Informe Epidemiológico do SUS 1998; 7(1):7-28.

Teutsch SM. Consideration in planning a surveillance system. In: Teutsch SM, Churchill RE, editors. Principles and practice of public health surveillance. New York: Oxford University Press; 1994. p.18-30.

Thacker SB, Berkelman RL. Public health surveillance in the United States. Epidemiol Rev 1988; 165-91.

Thacker SB, Parrish RG, Trowbridge FL, Surveillance Coordination Group. A method for evaluating system of epidemiological surveillance. Wld Hthl Statist Quart 1988; 41: 11-8

Thomas DL. Hepatitis C epidemiology. Curr Top Microbiol Immunol 1999; 242: $25-41$. 
Trinta KS, Liberto MIM, Paula VS, Yoshida CFT, Gaspar AMC. Hepatitis E infection in selected Brazilian populations. Mem Inst Oswaldo Cruz 2001; 96(1): 25-9.

Umemura T, Yeo AET, Sottini A, Moratto D, Takana Y, Wang RYH, et al. SEM Virus infection and its relationship to Transfusion- Associated Hepatitis. Hepatology 2001; 33(5): 1303-11.

Vitral CL, Yoshida CFT, Lemos ERS, Teixeira CS, Gaspar AMC. Age-specific prevalence of antibodies to hepatitis $\mathrm{A}$ in children and adolescents from Rio de Janeiro, Brazil, 1978 and 1995. Relationship of prevalence to environmental factors. Mem Inst Oswaldo Cruz 1998; 93(1): 1-5.

Vento S, Garofano T, Renzini C, Cainelli F, Casali F, Ghironzi G et al. Fulminant hepatitis associated with hepatitis A virus superinfection in patients with chronic hepatitis C. N Engl J Med 1998; 338 (5): 286-90.

Vogt RL, LaRue D, Klauche DN, Jillson DA. Comparison of an active and passive surveillance system of primary care providers for hepatitis, measles, rubella and salmonellosis in Vermont. Am J Public Health 1983; 73: 795-7.

Waldman EA. Vigilância epidemiológica como prática de saúde pública. São Paulo; 1991 [Tese de doutorado - Faculdade de Saúde Pública da Universidade de São Paulo].

Waldman EA. Vigilância em saúde pública. São Paulo: Faculdade de Saúde Pública da Universidade de São Paulo, 1998.

Westphal M F. Participação popular e a promoção de saúde da criança. São Paulo: Faculdade de Saúde Pública, 1998 [Relatório de Pesquisa, Departamento de Prática de Saúde Pública]. 
[WHO]. Public health control of hepatitis A: memorandum from a WHO meeting. Bull of WHO 1995; 73(1): 15-20.

Yarbough PO. Hepatitis E virus: advances in HEV biology and HEV vaccine approaches. Intervirology 1999; 42: 179-84.

Zachoval R, Deinhardt F. Hepatitis A virus: natural history and experimental models. In: Zuckerman AJ, Thomas H, editors. Viral hepatitis: Scientific basis and clinical management. $2^{\text {nd }}$ ed. London: Churchill Livingstone; 1998. p.43-58.

Zuckerman AJ, Thomas HC. Viral hepatitis: Scientific basis and clinical management. $2^{\text {nd }}$ ed. London: Churchill Livingstone; 1998. Preface. 
ANEXOS 
FICHA DE INVESTIGAÇÃO LABORATORIAL - SUSPEITO

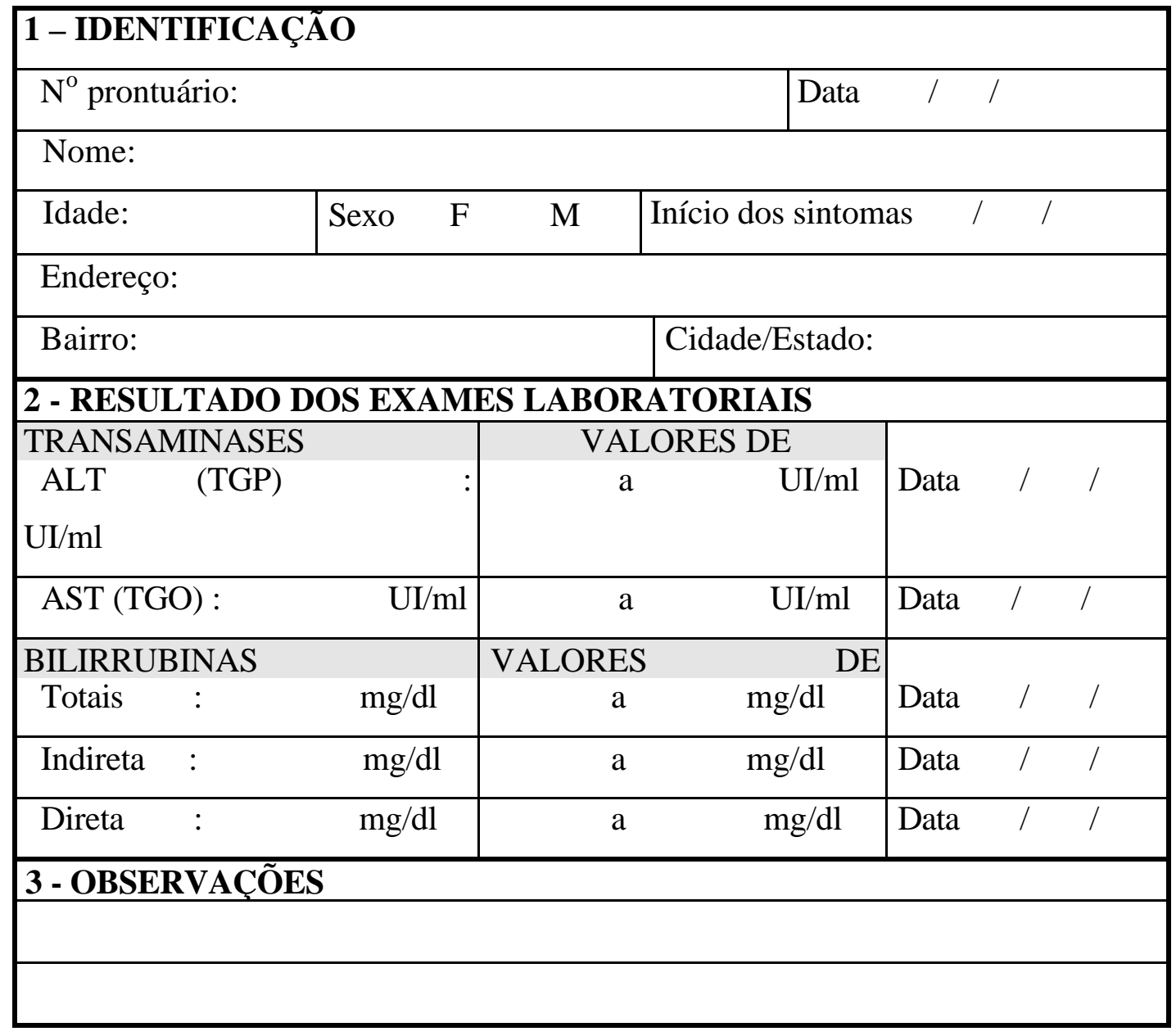

\begin{tabular}{|c|c|c|c|c|c|}
\hline \multicolumn{6}{|c|}{ PARA USO DO LABORATÓRIO DE HEPATITES } \\
\hline Data de entrada / / & \multicolumn{5}{c|}{ Número / VGP - } \\
\hline Iniciais & HBsAg & Anti-HBc & Anti-HAV & Anti- & Anti- \\
\hline Data reação & & & & & \\
\hline Kit / cut-off & & & & & \\
\hline Leitura & & & & & \\
\hline Complementare & Anti-HBc IgM & Anti-HBs & Anti-HBe & HBeAg & \\
\hline Data reação & & & & & \\
\hline Kit / cut-off & & & & & \\
\hline Leitura & & & & & \\
\hline \multicolumn{7}{|c|}{} & & & \\
\hline Observações do Laboratório & & & \\
\hline
\end{tabular}




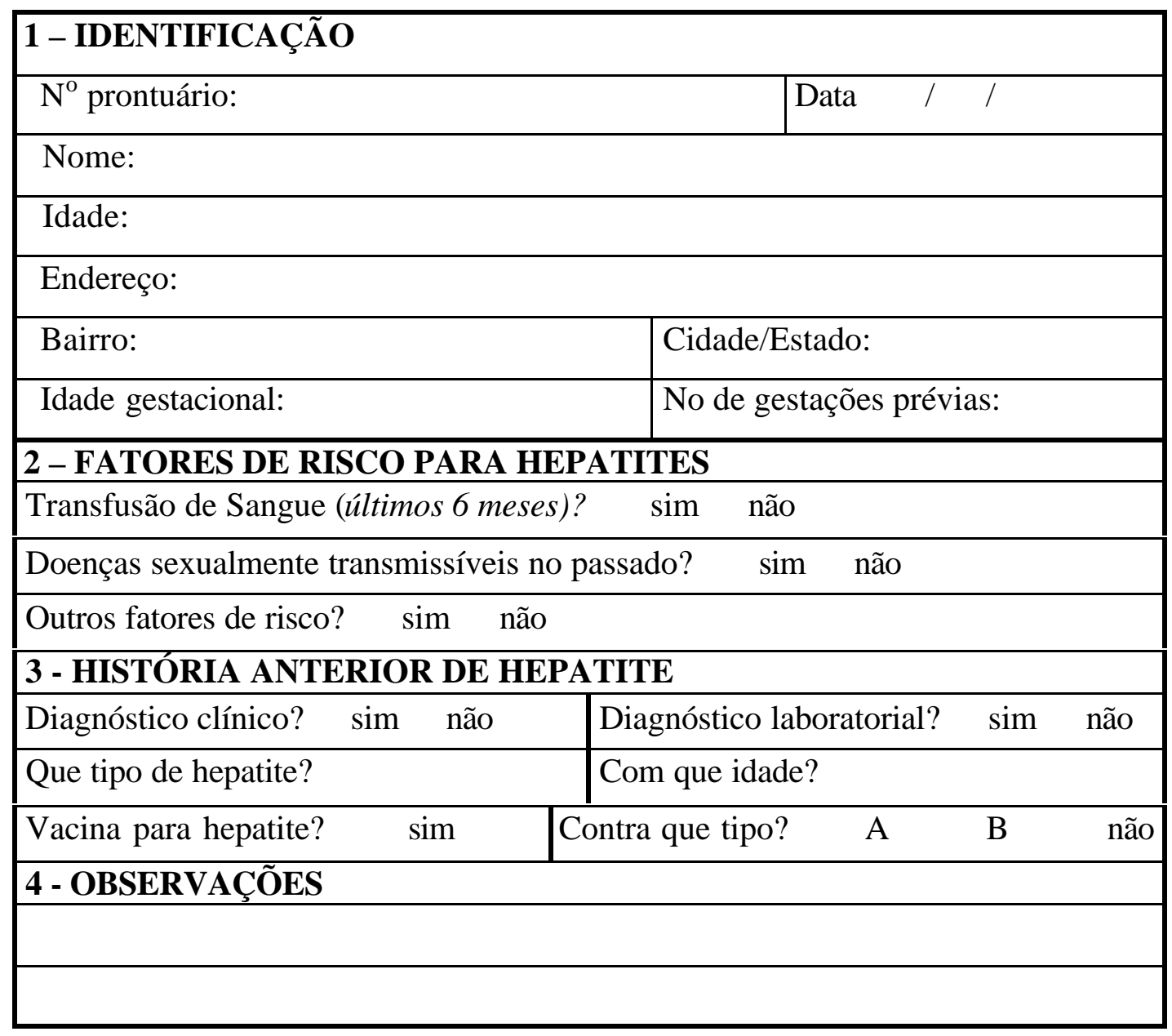

\begin{tabular}{|c|c|c|c|c|c|}
\hline \multicolumn{6}{|c|}{ PARA USO DO LABORATÓRIO DE HEPATITES } \\
\hline \multicolumn{6}{|c|}{$\begin{array}{llll}\text { Data de entrada } / \text { Número / VGP - } & / & \text {. }\end{array}$} \\
\hline Iniciais & HBsAg & Anti-HBc & Anti-HAV & Anti- & Anti- \\
\hline \multicolumn{6}{|l|}{ Data reação } \\
\hline \multicolumn{6}{|l|}{ Kit / cut-off } \\
\hline \multicolumn{6}{|l|}{ Leitura } \\
\hline Complementare & Anti-HBc IgM & Anti-HBs & Anti-HBe & $\mathrm{HBeAg}$ & \\
\hline \multicolumn{6}{|l|}{ Data reação } \\
\hline \multicolumn{6}{|l|}{ Kit / cut-off } \\
\hline \multicolumn{6}{|l|}{ Leitura } \\
\hline & & & & & \\
\hline \multicolumn{6}{|c|}{ Observações do Laboratório } \\
\hline
\end{tabular}


FICHA DE INVESTIGAÇÃO EPIDEMIOLÓGICA

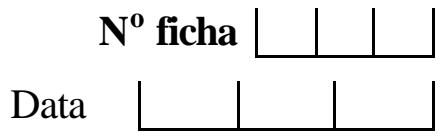

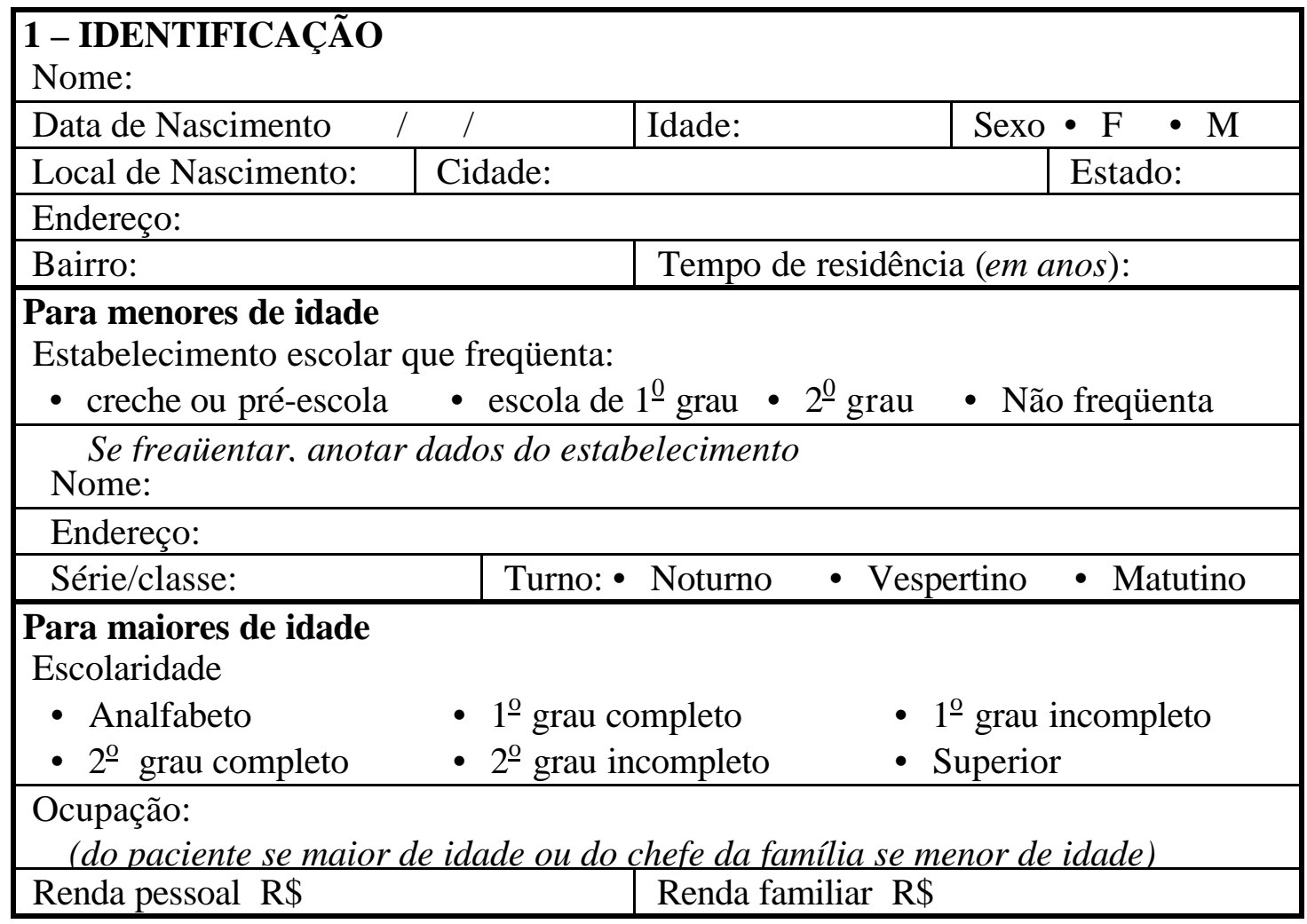

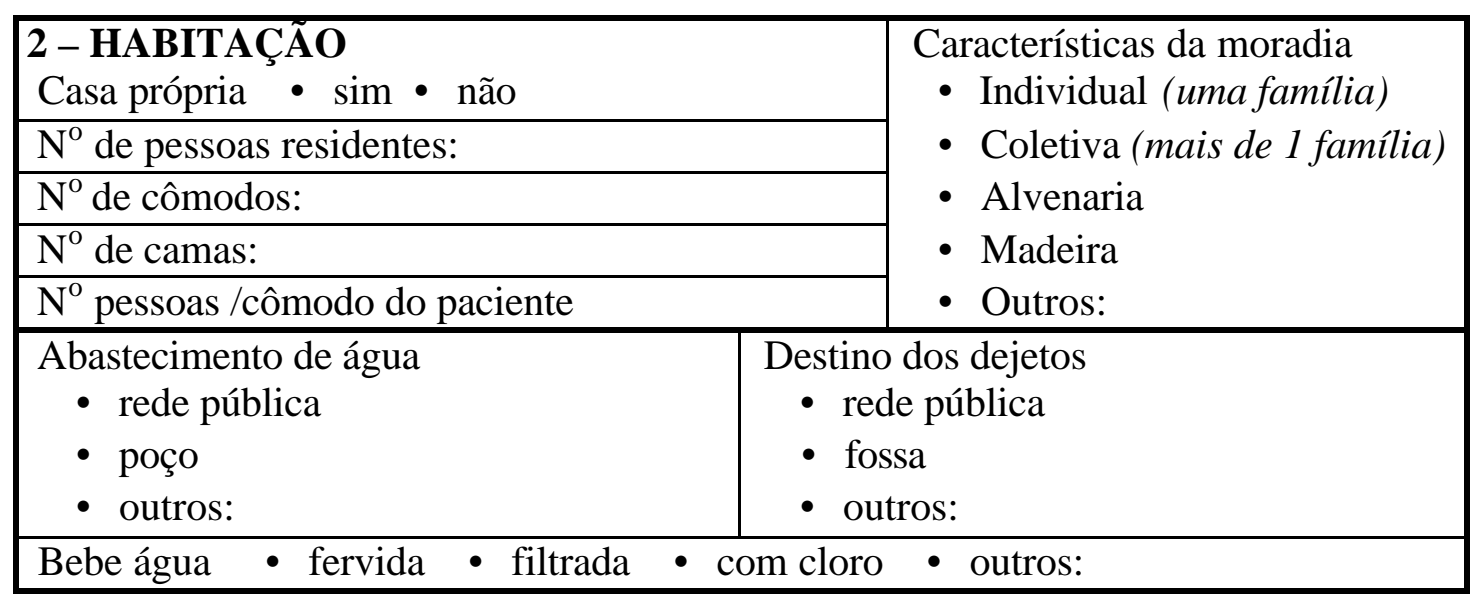

\begin{tabular}{|c|c|c|c|c|}
\hline $\begin{array}{l}3 \text { - BENS } \\
\text { - geladeira } \\
\text { - vídeo }\end{array}$ & $\begin{array}{ll}\text { - } & \text { fogão } \\
\text { - } & \text { freezer }\end{array}$ & $\begin{array}{l}\text { - } \text { rádio } \\
\text { - microondas }\end{array}$ & $\begin{array}{l}\text { - } \text { televisão } \\
\text { - computador }\end{array}$ & - automóvel \\
\hline
\end{tabular}

\begin{tabular}{|c|c|c|c|c|c|c|}
\hline \multicolumn{7}{|c|}{4 - RESIDENTES NO DOMICÍLIO } \\
\hline 1) Idade: & Sexo & - $\mathrm{F}$ & - $\mathrm{M}$ & 2) Idade: & Sexo $\bullet F$ & - $\mathrm{M}$ \\
\hline 3) Idade: & Sexo & - $\mathrm{F}$ & - $\mathrm{M}$ & 4) Idade: & Sexo $\bullet F$ & - $\mathrm{M}$ \\
\hline 5) Idade: & Sexo & - $\mathrm{F}$ & - $\mathrm{M}$ & 6) Idade: & Sexo $\bullet F$ & - $\mathrm{M}$ \\
\hline 7) Idade: & Sexo & - $\mathrm{F}$ & $\cdot \mathrm{M}$ & 8) Idade: & Sexo $・ F$ & - $\mathrm{M}$ \\
\hline
\end{tabular}




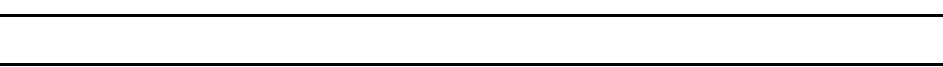

5 - DADOS CLÍNICO - EPIDEMIOLÓGICOS

Data do início dos primeiros sintomas: / /

Data do Diagnóstico: / /

Principais manifestações clínicas

- febre - icterícia - fezes claras - urina escura • artralgia - coceira

Outras manifestações significativas:

O Paciente é o Primeiro Caso de Hepatite da família, escola ou ambiente de trabalho nos últimos 6 meses? $\quad \bullet \operatorname{sim}($ campo $6 \mathbf{A}) \cdot \operatorname{não}($ campo $6 \mathbf{B})$

\section{A Paciente é o Primeiro Caso de Hepatite}

- Número de casos secundários no domicílio:

\begin{tabular}{|c|c|c|c|c|c|}
\hline & Parentesco & idade & sexo & inicio & diagnóstico / hepatite \\
\hline $1^{\mathrm{o}}$ & & & $\bullet \mathrm{F} \cdot \mathrm{M}$ & $/ \mathrm{I}$ & $\bullet \mathrm{A} \cdot \mathrm{B} \cdot \mathrm{C} \cdot \mathrm{E}$ Outro: \\
\hline $2^{\mathrm{o}}$ & & & $\bullet \mathrm{F} \cdot \mathrm{M}$ & $/ /$ & $\bullet \mathrm{A} \cdot \mathrm{B} \cdot \mathrm{C} \cdot \mathrm{E}$ Outro: \\
\hline $3^{\mathrm{o}}$ & & & $\bullet \mathrm{F} \cdot \mathrm{M}$ & $/ /$ & $\bullet \mathrm{A} \cdot \mathrm{B} \cdot \mathrm{C} \cdot \mathrm{E}$ Outro: \\
\hline $4^{\mathrm{o}}$ & & & $\bullet \mathrm{F} \cdot \mathrm{M}$ & $/ /$ & $\bullet \mathrm{A} \cdot \mathrm{B} \cdot \mathrm{C} \cdot \mathrm{E}$ Outro: \\
\hline
\end{tabular}

- № de casos secundários na escola:

\begin{tabular}{|c|c|c|c|c|}
\hline & idade & sexo & início dos sintomas & diagnóstico / hepat \\
\hline $1^{\underline{0}}$ caso & & - $\mathrm{F} \cdot \mathrm{M}$ & / / & - $\mathrm{A} \cdot \mathrm{B} \cdot \mathrm{C} \cdot \mathrm{E}$ outro: \\
\hline $2^{\circ}$ caso & & - $\mathrm{F} \cdot \mathrm{M}$ & 11 & - $\mathrm{A} \cdot \mathrm{B} \cdot \mathrm{C} \cdot \mathrm{E}$ outro: \\
\hline $3^{\circ}$ caso & & - $\mathrm{F} \cdot \mathrm{M}$ & & - $\mathrm{A} \cdot \mathrm{B} \cdot \mathrm{C} \cdot \mathrm{E}$ outro: \\
\hline $4^{\circ}$ caso & & - $\mathrm{F} \cdot \mathrm{M}$ & $1 /$ & - $\mathrm{A} \cdot \mathrm{B} \cdot \mathrm{C} \cdot \mathrm{E}$ outro: \\
\hline
\end{tabular}

- № de casos secundários no ambiente de trabalho:

\begin{tabular}{|c|c|c|c|c|}
\hline & idade & sexo & início dos sintomas & diagnóstico / hepatite \\
\hline $1^{\circ}$ caso & & - $\mathrm{F} \cdot \mathrm{M}$ & $1 /$ & - $\mathrm{A} \cdot \mathrm{B} \cdot \mathrm{C} \cdot \mathrm{E}$ outro: \\
\hline $2^{-}$caso & & - $\mathrm{F} \cdot \mathrm{M}$ & 11 & - $\mathrm{A} \cdot \mathrm{B} \cdot \mathrm{C} \cdot \mathrm{E}$ outro: \\
\hline $3^{\circ}$ caso & & - $\mathrm{F} \cdot \mathrm{M}$ & 11 & - $\mathrm{A} \cdot \mathrm{B} \cdot \mathrm{C} \cdot \mathrm{E}$ outro: \\
\hline $4^{\mathrm{O}}$ caso & & - $\mathrm{F} \cdot \mathrm{M}$ & $1 /$ & - $\mathrm{A} \cdot \mathrm{B} \cdot \mathrm{C} \cdot \mathrm{E}$ outro: \\
\hline
\end{tabular}

\begin{tabular}{|c|c|c|c|c|c|}
\hline & Pac & NÄ & Primeiro Ca & Hepatite & \\
\hline & Rela & ionar $O$ & mero de pessoas ati & gidas anteriormente pela & patite \\
\hline & idade & sexo & início dos sintomas & diagnóstico / hepatite & local* \\
\hline 1 & & - $\mathrm{F} \bullet$ & $1 /$ & - $\mathrm{A} \cdot \mathrm{B} \cdot \mathrm{C} \cdot \mathrm{E}$ outro: & $\cdot 1 \cdot 2 \cdot 3$ \\
\hline 2 & & - $\mathrm{F} \bullet$ & $1 /$ & - $\mathrm{A} \cdot \mathrm{B} \cdot \mathrm{C} \cdot \mathrm{E}$ outro: & $\cdot 1 \cdot 2 \cdot 3$ \\
\hline 3 & & - $\mathrm{F} \bullet$ & / & - $\mathrm{A} \cdot \mathrm{B} \cdot \mathrm{C} \cdot \mathrm{E}$ outro: & $\cdot 1 \cdot 2 \cdot 3$ \\
\hline 4 & & - $\mathrm{F} \bullet$ & l & - $\mathrm{A} \cdot \mathrm{B} \cdot \mathrm{C} \cdot \mathrm{E}$ outro: & - $1 \cdot 2 \cdot 3$ \\
\hline 5 & & - $\mathrm{F} \bullet$ & / & - $\mathrm{A} \cdot \mathrm{B} \cdot \mathrm{C} \cdot \mathrm{E}$ outro: & - $1 \cdot 2 \cdot 3$ \\
\hline & & & 1 & - escola 3-trabalho & \\
\hline
\end{tabular}

\begin{tabular}{|c|c|}
\hline \multicolumn{2}{|c|}{ 7- HISTÓRIA ANTERIOR DE HEPATITE } \\
\hline \multicolumn{2}{|c|}{ Quando? } \\
\hline Diagnostico clínico $\bullet \operatorname{sim} \bullet$ não & Diagnostico laboratorial $\bullet \operatorname{sim} \bullet$ não \\
\hline Que tipo de hepatite: & Data da alta da hepatite / / \\
\hline \multicolumn{2}{|l|}{ Condições de alta: } \\
\hline Vacina para hepatite $\mathrm{B} \cdot \operatorname{sim} \bullet$ não & № de doses: \\
\hline Vacina para hepatite $\mathrm{A}$ & Data / / \\
\hline
\end{tabular}




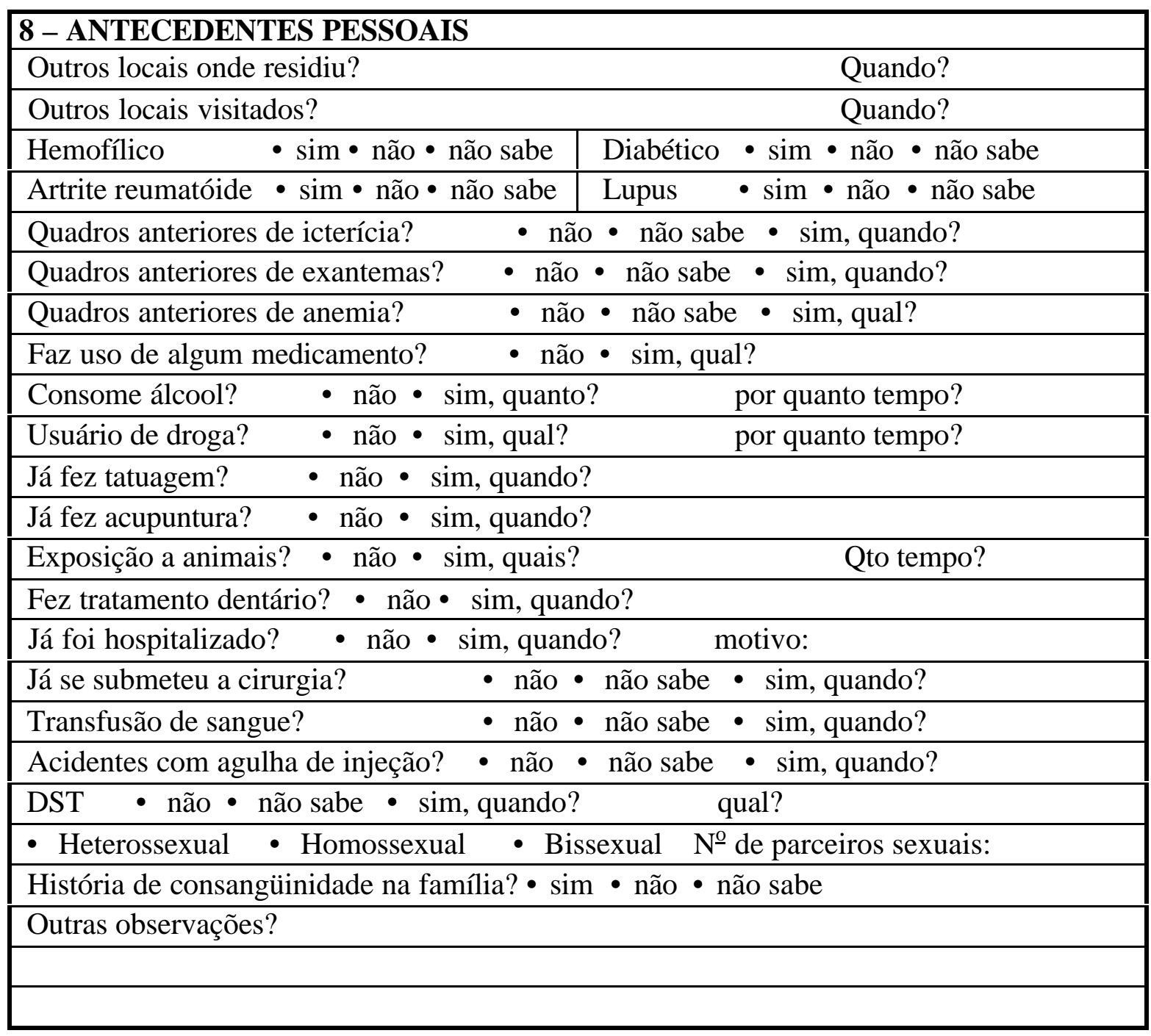




\section{ANEXO 4}

TERMO DE CONSENTIMENTO LIVRE E ESCLARECIDO

(Obrigatório para Pesquisa Científica em Seres Humanos - Resolução ñ 196 de

$$
\text { 10/10/96 - CNS) }
$$

\section{I - Dados de identificação do paciente ou responsável legal}

\begin{tabular}{|c|c|c|c|c|}
\hline \multicolumn{5}{|c|}{ Paciente ou responsável legal: } \\
\hline \multicolumn{3}{|c|}{ Documento de Identidade: } & Sexo: $M$ & $\mathrm{~F} \bullet$ \\
\hline \multicolumn{5}{|l|}{ Endereço: } \\
\hline \multicolumn{2}{|l|}{ Bairro: } & \multicolumn{2}{|l|}{ Cidade: } & Tel \\
\hline \multirow{2}{*}{$\begin{array}{l}\text { Nome das } \\
\text { crianças: }\end{array}$} & 1 & 2 & & 3 \\
\hline & 4 & 5 & & 6 \\
\hline
\end{tabular}

Grau de parentesco do responsável: 


\section{II - Dados sobre a Pesquisa Científica}

\section{Título da Pesquisa: ASPECTOS EPIDEMIOLÓGICOS DAS HEPATITES VIRAIS EM VARGEM GRANDE PAULISTA, SP.}

2. Coordenador do Projeto: Prof. Dr. Eliseu Alves Waldman, que pode ser encontrado na Faculdade de Saúde Pública, no telefone 883-5738

3. Objetivos da pesquisa: estudar e acompanhar os casos de hepatite viral no Município de Vargem Grande Paulista

4. Benefícios da pesquisa: você terá acesso aos resultados, através da Dra Virgínia R. de Celis e se for portador crônico de hepatite será encaminhado ao Grupo de Hepatologia do Hospital das Clínicas, sob responsabilidade do Dr. Flair José Carrilho

5. Risco da pesquisa: a pesquisa oferece riscos mínimos já que serão colhidos 5 $\mathrm{mL}$ de sangue da veia do antebraço utilizando materiais estéreis e descartáveis 6. Compromisso da pesquisa: em nenhum momento, você será identificado; será mantido o caráter confidencial dos resultados; a amostra de sangue colhida será utilizada exclusivamente para a pesquisa dos vírus que causam hepatites.

\section{III - Consentimento Pós-esclarecido}

Declaro, após ter sido convenientemente esclarecido(a) pelo pesquisador, que concordei em participar do projeto de pesquisa acima discriminado, respondendo a questionário e autorizando a colheita de amostra de sangue.

data:

Assinatura do Paciente

(Este termo será preenchido em duas vias: uma para o paciente e a outra para o pesquisador) 
ANEXO 5

TERMO DE CONSENTIMENTO LIVRE E ESCLARECIDO

(Obrigatório para Pesquisa Científica em Seres Humanos - Resolução ño 196 de

$$
10 / 10 / 96-\text { CNS) }
$$

\section{I - Dados de identificação da gestante}

Gestante:

Documento de Identidade:

Endereço:

\begin{tabular}{|l|l|l|}
\hline Bairro: & Cidade: & Tel.: \\
\hline
\end{tabular}

\section{II - Dados sobre a Pesquisa Científica}

\section{Título da Pesquisa: ASPECTOS EPIDEMIOLÓGICOS DAS HEPATITES VIRAIS EM VARGEM GRANDE PAULISTA, SP.}

2. Coordenador do Projeto: Prof. Dr. Eliseu Alves Waldman, que pode ser encontrado na Faculdade de Saúde Pública, no telefone 883-5738

3. Objetivos da pesquisa: estudar e acompanhar os casos de hepatite viral nas gestantes matriculadas no Serviço de Pré-natal de Vargem Grande Paulista

4. Benefícios da pesquisa: você terá acesso aos resultados através do médico responsável do Serviço Pré-natal; as portadoras do vírus da hepatite B serão orientadas quanto a necessidade de vacinar o recém nascido. As portadoras de hepatite C serão encaminhadas ao Grupo de Hepatologia do Hospital das Clínicas, sob responsabilidade do Dr. Flair José Carrilho

5. Risco da pesquisa: a pesquisa oferece riscos mínimos já que serão colhidos 5 $\mathrm{mL}$ de sangue da veia do antebraço utilizando materiais estéreis e descartáveis

6. Compromisso da pesquisa: em nenhum momento você será identificada; será mantido o caráter confidencial dos resultados; a amostra de sangue colhida será utilizada exclusivamente para a pesquisa dos vírus que causam hepatites. 


\section{III - Consentimento Pós-esclarecido}

Declaro, após ter sido convenientemente esclarecido(a) pelo pesquisador, que concordei em participar do projeto de pesquisa acima discriminado, respondendo a questionário e autorizando a colheita de amostra de sangue.

data:___ _ _ _ _

Assinatura da gestante

(Este termo será preenchido em duas vias: uma para a gestante e a outra para o pesquisador) 